\title{
Effects of constant incubation regimes on eggs and hatchlings of the egg-laying skink, Oligosoma suteri
}

\author{
Kelly Maree Hare
}

A thesis submitted as partial fulfilment for the degree of Master of Science in Ecology

Victoria University of Wellington

Te Whare Wananga o te Upoko o te Ika a Maui 2001 



\begin{abstract}
The conditions under which reptilian eggs are incubated affect survival probability and physiological attributes of the progeny. The egg-laying skink, Oligosoma suteri, is the only endemic oviparous lizard in New Zealand. No controlled laboratory incubation had previously been undertaken, and thus no information was available on the requirements for successful captive incubation. I studied the effects of incubation regime on the eggs and hatchlings of $O$. suteri to four months of age. Oligosoma suteri eggs $(n=174)$ were randomly distributed among three constant incubation temperatures $\left(18^{\circ} \mathrm{C}, 22^{\circ} \mathrm{C}\right.$ and $\left.26^{\circ} \mathrm{C}\right)$ and two water potentials $(-120 \mathrm{kPa}$ and $-270 \mathrm{kPa})$. Hatching success and hatchling survival were greatest at $22^{\circ} \mathrm{C}$ and $26^{\circ} \mathrm{C}$, with hatchlings from $18^{\circ} \mathrm{C}$ incubation suffering from physical abnormalities. Incubation regime and maternal influence did not affect sex of individuals, with equal sex ratios occurring from each incubation treatment. Hatchlings from the $22^{\circ} \mathrm{C}$ and $-120 \mathrm{kPa}$ incubation treatments were larger, for most measurements, and warmer incubation temperatures resulted in increased growth rates. Juveniles from $22^{\circ} \mathrm{C}$ and $26^{\circ} \mathrm{C}$ and individuals with greater mass per unit length (condition index) sprinted faster over 0.25 m. Sprint speed was positively correlated with ambient temperature. At four months of age sprint speed decreased in $18^{\circ} \mathrm{C}$ individuals and individuals incubated at $26^{\circ} \mathrm{C}$ and $-270 \mathrm{kPa}$ compared to their performance at one month. The results suggest that the most successful captive incubation regime for $O$. suteri is $22^{\circ} \mathrm{C}$ and $-120 \mathrm{kPa}$. This study also shows that temperature-dependent sex determination does not occur in $O$. suteri, but that fitness traits are influenced by incubation temperature.
\end{abstract}




\section{Acknowledgements}

I have many people that I would like to thank for their assistance, support, ideas and understanding - all of them made this thesis possible and worthwhile.

Sincere thanks to: my friend and supervisor Charles Daugherty, who introduced the wonderful world of reptiles and provided a calming influence during my 'stressed' stage(s). Nicola Nelson, who proved to be invaluable in all aspects of this project, from laboratory work and baby-sitting to editing (again and again). Susan Keall, who, after 6 days of isolation with yours truly on Green Island still talks to me. The 'Australian', Michael ' $\mathrm{B}$ ' Thompson, for letting me pick his brain and for his excellent sense of humour over the egg incident. Alison Cree, for teaching the art of interpreting gonad histology as well as confirming the sexes of individuals. And Shirley Pledger, who kindly gave up so much of her valuable time to help me with statistical nightmares. Other people have contributed their time and expertise: Geoff Birchard determined the water potential and let me borrow his equipment in the field; Richard Moore who kept up a steady supply of sacrificial insects; Chris Thorn who sectioned many skinks and taught me histology techniques; and of course Dave Towns who imparted so much knowledge about Oligosoma suteri and the Mercury Islands. I would also like to thank Fred Allendorf, Ian Atkinson, Ana Djorovic, Chris Green, Rod Hitchmough, Edith Hodgen, Alan Hoverd, Gary Jowett, Nicola Mitchell, Andrew Styche and the School of Biological Sciences Staff for their assistance.

Thanks also to Victoria University of Wellington, the Department of Conservation (Permit - ISL 004), and the Ngati Maru and Ngati Whanaunga, for allowing me to work on such an exciting project and in such a wonderful area of New Zealand.

Special thanks to skink 5555, all of Charlie's Angels and to VUW friends I have made on the way, as well as all my 'school' friends who didn't give up on me when I disappeared for weeks on end (of course you all knew that I was hopelessly lost in the orange linoleum floors of SBS).

I would especially like to thank Martin Rea and my parents David and Marie, who gave me so much support and encouragement. I couldn't have done it without you all. 


\section{Table of Contents}

Abstract $\quad$ i

Acknowledgements $\quad$ ii

Table of Contents iii

CHAPTER 1 Incubation, sex determination, fitness and the egg-laying skink, Oligosoma suteri: introduction and overview 1

1.1 Effects of incubation regime 2

1.1.1 Sex determination in reptiles 2

1.1.2 Biological fitness 3

$\begin{array}{lll}1.2 & \text { The egg-laying skink, } O \text {. suteri } 5\end{array}$

1.2.1 Phylogeny 5

1.2.2 Ecology and reproduction 5

1.2.3 Conservation 6

1.3 Study objectives 6

$\begin{array}{lll}1.4 & \text { References } & 7\end{array}$

CHAPTER 2 Incubation regime affects morphology and incubation period but not sex of the egg-laying skink, Oligosoma suteri 12

$\begin{array}{lll}2.1 & \text { Introduction } & 12\end{array}$

$\begin{array}{lll}2.2 & \text { Methods } & 14\end{array}$

$\begin{array}{lll}2.2 .1 & \text { Study area } & 14\end{array}$

$\begin{array}{ll}\text { 2.2.2 Collection of gravid females } & 15\end{array}$

$\begin{array}{lll}2.2 .3 & \text { Husbandry } & 15\end{array}$

$\begin{array}{lll}2.2 .4 & \text { Incubation of eggs } & 16\end{array}$

$\begin{array}{ll}\text { 2.2.5 Sex identification of juveniles } & 17\end{array}$

$\begin{array}{lll}2.2 .6 & \text { Data analysis } & 18\end{array}$

$\begin{array}{lll}2.3 & \text { Results } & \mathbf{2 0}\end{array}$

$\begin{array}{lll}2.3 .1 & \text { Eggs } & 20\end{array}$

2.3.2 Hatching success and hatchling morphology 23

2.3.3 Identification of hatchling sex 25

$\begin{array}{lll}2.3 .4 & \text { Sex ratio } & 27\end{array}$ 
2.4 Discussion 29

2.4.1 Maternal influence $\quad 29$

2.4.2 Incubation period, eggs and hatching success 30

$\begin{array}{lll}2.4 .3 & \text { Sex ratio } & 31\end{array}$

$\begin{array}{lll}2.4 .4 & \text { Sexual characters } & 31\end{array}$

2.4.5 Ecological implications $\quad 32$

2.4.6 Conclusion $\quad 32$

$\begin{array}{lll}2.5 & \text { References } & 33\end{array}$

CHAPTER 3 Incubation regime affects performance of the egg-laying skink, $\begin{array}{ll}\text { Oligosoma suteri } & 37\end{array}$

$\begin{array}{lll}3.1 & \text { Introduction } & 37\end{array}$

3.2 Methods 39

3.2.1 Incubation of eggs 39

3.2.2 Maintenance of juveniles $\quad 39$

3.2.3 Locomotor performance 40

3.2.4 Data analysis 41

$\begin{array}{lll}3.3 & \text { Results } & 43\end{array}$

3.3.1 Hatchling size, survival and growth 43

$\begin{array}{lll}\text { 3.3.2 Locomotor performance } & 47\end{array}$

3.4 Discussion 49

3.4.1 Hatchling size, survival and growth 49

$\begin{array}{lll}3.4 .2 & \text { Locomotor performance } & 51\end{array}$

$\begin{array}{lll}3.4 .3 & \text { Implications } & 51\end{array}$

$\begin{array}{lll}3.4 .4 & \text { Conclusion } & 52\end{array}$

$\begin{array}{lll}3.5 & \text { References } & 53\end{array}$

$\begin{array}{lr}\text { CHAPTER } 4 \text { Summary and recommendations } & 57\end{array}$

$\begin{array}{lll}4.1 & \text { Summary of results } & 57\end{array}$

$\begin{array}{lll}4.2 & \text { Recommendations } & 58\end{array}$

$\begin{array}{lll}4.3 & \text { Future research } & 58\end{array}$ 
A) Green Island female Oligosoma suteri, December $1999 \quad 60$

B) Captive incubated and reared Oligosoma suteri 62

$\begin{array}{ll}\text { APPENDIX II Histology } & 66\end{array}$

A) Fixation and storage $\quad 66$

B) Embedding $\quad 67$

$\begin{array}{ll}\text { C) Sectioning and staining } & 68\end{array}$

APPENDIX III Results from statistical analyses $\quad 69$

A) Chapter 2 results - maternal effects, incubation period, $\quad 69$ egg mass and hatching success

B) Chapter 3 results - hatchling size, condition index, growth, 71 locomotor performance and survival 


\section{CHAPTER ONE \\ Incubation, sex determination, fitness and the \\ egg-laying skink, Oligosoma suteri: \\ introduction and overview}

Hatchling survival probability and physiological attributes, such as sex, fitness and growth, are key components in conservation programs of oviparous (egg-laying) reptiles. In New Zealand, tuatara (Sphenodon) eggs have been incubated under controlled laboratory conditions to determine the requirements necessary for successful incubation (Thompson 1990). This study also led to the discovery of temperaturedependent sex determination (TSD) in tuatara (Cree et al. 1995), which in turn meant that particular incubation regimes could be designed to produce juveniles of both sexes for establishment of new populations (Daugherty 1998).

New Zealand's only other endemic oviparous reptile, the egg-laying skink, Oligosoma suteri, has had both its ecology and reproductive biology described (Towns 1975a, b, Whitaker 1968), but no controlled laboratory incubation has been undertaken. Thus, no information is available on the requirements for successful captive incubation, nor the effects of different incubation regimes on physiological attributes of $O$. suteri. In the past, inadequate understanding of incubation regime and its impact on reptile physiology and reproduction has led to poor management. For example, before the discovery of TSD in the loggerhead sea turtle (Caretta caretta), conservation methods included incubation of eggs in styrofoam boxes in sheltered locations on beaches (Mrosovsky and Yntema 1980). The cool temperatures experienced by embryos resulted in a male biased sex ratio, thus compromising conservation of the species. 


\subsection{Effects of incubation regime}

In reptiles, incubation temperatures (both constant and variable) have been found to affect incubation period, embryonic survival, sex, size at hatching, morphology, growth rate, locomotor performance, thermoregulatory behaviour and juvenile survival (e.g. Alberts et al. 1997, Allsteadt and Lang 1995, Andrews et al. 2000, Bull 1980, Choo and Chou 1987, Elphick and Shine 1998). Embryos of reptiles develop faster at warmer temperatures than cooler temperatures, with highest survival at an optimal (usually intermediate) temperature (Christian 1986, Packard and Packard 1987, Plummer et al. 1994). Inappropriate incubation temperature may have dire effects on embryos and hatchlings. For example, the snake Python molurus develops normally at $30.5^{\circ} \mathrm{C}$, but abnormally at $27.5^{\circ} \mathrm{C}$, when deformities such as kinking of vertebral column occur (Vinegar 1974).

The availability of water to soft-shelled eggs during incubation also influences numerous aspects of hatchling reptile phenotypes. Most of this work has been undertaken on turtles, but eggs of oviparous squamate reptiles usually have thin flexible shells, with little resistance to water movement from the surrounding environment (Packard et al. 1982). Therefore, moisture levels during incubation also affect them. Physiological attributes affected by water potential include incubation time, oxygen uptake of the embryo, embryo survival, hatchling size, growth and locomotor performance (e.g. Cagle et al. 1993, Gettinger et al. 1984, Miller et al. 1987, Morris et al. 1983, Packard and Phillips 1994). Water potential was also thought to determine sex (Gutzke and Paukstis 1983), but this has since been discredited (Packard et al. 1989, Packard et al. 1991).

\subsubsection{Sex determination in reptiles}

Sex determining mechanisms in animals are varied. In reptiles there are two known mechanisms, genetic sex determination (GSD) and environmental sex determination (ESD). GSD occurs when the sex of the offspring is irreversibly fixed by its genotype (Bull 1980). This includes the XX/XY system, where the male has heteromorphic sex chromosomes, and the ZZ/ZW system, where the female has the heteromorphic sex chromosomes (Russell 1998). ESD occurs when the environment encountered as an embryo determines the sex of the offspring. Temperature-dependent sex determination 
is a special case of ESD and is common in reptiles (Bull 1980). The thermosensitive period for sex determination in reptiles occurs between specific stages, usually in the middle third to half of development (Birchard and Reiber 1995, Bull 1981).

The first report of TSD in reptiles was in the agamid lizard Agama agama (Charnier 1966). Since then only two other lizard families (Eublepharidae and Gekkonidae) have convincingly demonstrated TSD (Harlow 2000, Viets et al. 1994). To date, TSD has only been reported in one species of skink, the viviparous Australian skink Eulamprus tympanum (M.B. Thompson pers. comm.). The presence of heteromorphic sex chromosomes in reptiles coincides with genetically determined sex (GSD) and a lack of TSD; GSD is most common in squamates (Viets et al. 1994). To date, there is no record of TSD in snakes (Order Squamata), but incubation temperatures do differentially affect embryonic mortality in the snake Pituophis melanoleucus (Burger and Zappaloorti 1988). TSD also occurs among crocodiles, tuatara and turtles, although a few species of turtles have distinct sex chromosomes (Cree et al. 1995, Ewert and Nelson 1991, Ferguson and Joanen 1982, Mittwoch 1996).

Three patterns of sex ratio have been discovered in response to temperature. These include:

Ia (MF): males at low temperatures and females at high temperatures (many turtle species);

Ib (FM): females at low temperatures and males at high temperatures (alligators, some lizards and Sphenodon punctatus);

II (FMF): females at low and high temperatures and males at intermediate temperatures (crocodiles, some lizards, and snapping turtles; Bull 1980, Cree et al. 1995, Mittwoch 1996).

Although TSD appears to have evolved many times, its significance and origins are still unresolved (Janzen 1995, Shine 1995).

\subsubsection{Biological fitness}

Biological fitness is the ability of an organism to transfer its genes to the next generation (Hale et al. 1995). Studies of biological fitness should estimate the contribution of individuals, genotypes and phenotypes to the gene pool for each generation. However, it is seldom possible to measure lifetime reproductive success in a single individual or population, even for one generation. Instead performance 
correlates of phenotypic traits, such as size, growth and locomotor performance, are frequently used to infer overall fitness of individuals, by their presumed influence on an organism's ability to survive to maturity and thus contribute to the gene pool (Russell 1998).

In oviparous reptile species phenotypic traits such as hatchling size can be influenced by variation in initial egg size, egg quality, incubation conditions or combinations of these factors (Crump 1984, Packard and Phillips 1994). Usually, individuals are larger when incubated at optimal incubation temperatures and wetter water potentials. For example, Crocodylus niloticus hatchlings are significantly longer from $31^{\circ} \mathrm{C}$ incubation temperatures than from $28^{\circ} \mathrm{C}$ or $34^{\circ} \mathrm{C}$ (Hutton 1987), and painted turtles (Chrysemys picta) are larger when hatched from eggs incubated at wet rather than dry water potentials (Packard et al. 1991). Incubation conditions also have long-term effects on post-hatching growth, behaviour and locomotor performance in reptiles (Burger 1989, Joanen et al. 1987). For example, individuals of the skink Bassiana duperreyi incubated in warm conditions $\left(27^{\circ} \mathrm{C} \pm 4^{\circ} \mathrm{C}\right)$ are faster than cool incubated siblings $\left(20^{\circ} \mathrm{C} \pm 4^{\circ} \mathrm{C}\right)$ to 20 weeks of age (Elphick and Shine 1998).

Locomotion based fitness tests are performed to evaluate the ability of young lizards to avoid predators. Greater locomotor performance, such as faster sprint speed, may allow individuals to evade predators more successfully and have greater ability to catch food, which can then increase growth rate and thus size at maturity and reproductive success (Downes and Shine 1999, Froese and Burghadt 1974, Jayne and Bennett 1990). Greater locomotor and competitive ability also increase survival probability of large hatchling lizards (Ferguson and Fox 1984, Ferguson and Joanen 1982, Fox 1978), snakes (Jayne and Bennett 1990), and turtles (Alho et al. 1985, Janzen 1993) during the neonatal period compared with small hatchlings in the same cohort. 


\subsection{The egg-laying skink, O. suteri}

\subsubsection{Phylogeny}

There are two families of endemic lizards in New Zealand, the Gekkonidae (geckos) and Scincidae (skinks). Currently 37 extant gecko and 34 extant skink species are known (C. H. Daugherty and R. A. Hitchmough pers. comm.), although this number is likely to increase as more research is carried out. The New Zealand skink genera include eight species of Cyclodina and 26 species of Oligosoma (C. H. Daugherty and R. A. Hitchmough pers. comm.). The genus Oligosoma was formerly classified in Leiolopisma (Hardy 1977), but changed in 1995 when it was found that Oligosoma species are differentiated both morphologically and genetically from the Australian Leiolopisma (Patterson and Daugherty 1995).

Oligosoma suteri is the only endemic oviparous lizard species in New Zealand (Whitaker 1968). Preliminary work suggests that it is phylogenetically nested within the endemic lizards of New Zealand (Smith et al. 2001). New Zealand is the only landmass in the Pacific region where there is such a dominance of viviparity (livebearing) over oviparity in the endemic lizards (Robb 1973).

\subsubsection{Ecology and reproduction}

Oligosoma suteri are black, grey or brown in colour, with black or dark brown, indistinct spots on the dorsal surface and flanks (Gill and Whitaker 1996). They have grey, pink or orange undersides and can reach a maximum snout-vent length of $108 \mathrm{~mm}$ (Gill and Whitaker 1996). Their distribution is confined to the upper North Island, being widespread on north-eastern offshore islands (Thoresen 1967). A limited number also exist at a few mainland sites from Cape Reinga to Port Jackson (Gill and Whitaker 1996, Fawcett 1971). Survival of O. suteri exceeds 12 years on offshore islands, but is probably lower on mainland New Zealand due to mammalian predators (Towns and Daugherty 1994, Towns and Ferreira 2001). Oligosoma suteri are restricted to boulder or shingle beaches and rocky platforms in the splash zone (Towns 1975a, Whitaker 1973). Although nocturnal, mainly hiding by day in crevices or under piles of seaweed, they are known to bask in captivity (Gill and Whitaker 1996, Towns 1975a). 
Female $O$. suteri lay two to five eggs in the summer (mid December to early January) in sand or soil deposits beneath large stones above high tide (Towns 1975a), with some females sharing nests (Gill and Whitaker 1996). Their eggs are oval and leathery, on average $15 \mathrm{~mm}$ long and $10 \mathrm{~mm}$ wide (Whitaker 1968). Incubation takes up to three months in the wild with eggs swelling by up to a third of the original volume by the time of hatching (Whitaker 1968).

\subsubsection{Conservation}

Although legally protected both by the Wildlife Act 1953 (Part I: Section 3 amendment Statutory Regulation 2(1) 1996) and by its occurrence on various island sanctuaries, O. suteri is neither rare nor endangered (Towns 1988). However, if $O$. suteri is found to have its sex ratio and fitness influenced by incubation regime, then this could have major implications on their future survival. As their distribution is limited and their habitat restricted, demographic and environmental stochasticity could vary their population structure between beaches, islands or with climate change, with possibly harmful long-term consequences to the species. Therefore, the study of incubation regime effects on sex ratio and fitness is important in the ongoing conservation of populations, and ultimately the species.

\subsection{Study objectives}

This thesis investigates the effects of different incubation temperatures and water potentials on physiological attributes of $O$. suteri eggs and hatchlings. In particular, I determine the conditions required for successful artificial incubation, focusing on incubation period, hatching success, hatchling morphology and sex (Chapter 2), as well as the differences in fitness correlates among different treatment groups, focusing on sprint speed, hatchling size, growth and survival (Chapter 3). Chapters 2 and 3 are written as separate manuscripts to be submitted for publication, so some repetition of general information occurs. A synopsis of general findings and recommendations for future research are detailed in Chapter 4. 


\subsection{References}

Alberts, A. C., A. M. Perry, J. M. Lemm and J. A. Phillips. 1997. Effects of incubation temperature and water potential on growth and thermoregulatory behaviour of hatchling Cuban rock iguanas (Cyclura nubila). Copeia 1997(4): 766-776.

Alho, C. J. R., T. M. S. Danni and L. F. M. Padua. 1985. Temperature-dependent sex determination in Podocnemis expansa (Testudinata: Pelomedusidae). Biotropica 17: 75-78.

Allsteadt, J. and J. W. Lang. 1995. Incubation temperature affects body size and energy reserves of hatchling American alligators (Alligator mississippiensis). Physiological Zoology 68(1): 76-97.

Andrews, R. M., T. Mathies and D. A. Warner. 2000. Effect of incubation temperature on morphology, growth, and survival of juvenile Sceloporus undulatus.

Herpetological Monographs 14: 420-431.

Birchard, G. F. and C. L. Reiber. 1995. Growth, metabolism, and chorioallantoic vascular density of developing snapping turtles (Chelydra serpentina): influence of temperature. Physiological Zoology 68(5): 799-811.

Bull, J. J. 1980. Sex determination in reptiles. The Quarterly Review of Biology 55(1): 3-21.

Bull, J. J. 1981. Sex ratio evolution when fitness varies. Heredity 46(1): 9-26.

Burger, J. 1989. Incubation temperature has long-term effects on behaviour of young pine snakes (Pituophis melanoleucus). Behavioural Ecology and Sociobiology 24: 201-207.

Burger, J. and R. T. Zappaloorti. 1988. Effects of incubation temperature on sex ratios in pine snakes: differential vulnerability of males and females. The American Naturalist 132(4): 492-505.

Cagle, K. D., G. C. Packard, K. Miller and M. J. Packard. 1993. Effects of the microclimate in natural nests on development of embryonic painted turtles, Chrysemys picta. Functional Ecology 7: 653-660.

Charnier, M. 1966. Action de la temperature sur la sex-ratio chez l'embryon d' Agama agama (Agamidae, Lacertilian). Comp. Rend. Soc. Biol. 160: 620-622.

Choo, B. L. and L. M. Chou. 1987. Effect of temperature on the incubation period and hatchability of Trionyx sinensis Weigmann eggs. Journal of Herpetology 21(3): 230-232.

Christian, K. A. 1986. The effect of cold exposure during incubation of Sceloporus undulatus eggs. Copeia 1986(4): 1012-1014.

Cree, A., M. B. Thompson and C. H. Daugherty. 1995. Tuatara sex determination. Nature 375: 543. 
Crump, M. L. 1984. Intraclutch egg size variability in Hyla crucifer (Anura: Hylidae). Copeia 1984(2): 302-308.

Daugherty, C. H. 1998. From dark days to a bright future: survival of the tuataras. ZooNooz April: 8-13.

Downes, S. J. and R. Shine. 1999. Do incubation-induced changes in a lizard's phenotype influence its vulnerability to predators? Oecologia 120(1): 9-18.

Elphick, M. J. and R. Shine. 1998. Longterm effects of incubation temperatures on the morphology and locomotor performance of hatchling lizards (Bassiana duperreyi, Scincidae). Biological Journal of the Linnean Society 63: 429-447.

Ewert, M. and C. E. Nelson. 1991. Sex determination in turtles: diverse patterns and some possible adaptive values. Copeia 1991(1): 50-69.

Fawcett, J. D. 1971. Note on the occurrence of the black shore skink, Leiolopisma suteri, Port Jackson, North Island, New Zealand. New Zealand Journal of Science 14: 1112-1114.

Ferguson, G. W. and S. F. Fox. 1984. Annual variation of survival advantage of large juvenile side-blotched lizards, Uta stansburiana: its causes and evolutionary significance. Evolution 38: 342-349.

Ferguson, M. W. J. and T. Joanen. 1982. Temperature of egg incubation determines sex in Alligator mississippiensis. Nature 296: 850-853.

Fox, S. F. 1978. Natural selection on the behavioural phenotypes of the lizard Uta stansburiana. Ecology 59: 834-847.

Froese, A. D. and G. M. Burghadt. 1974. Food competition in captive juvenile snapping turtles, Chelydra serpentina. Animal Behaviour 22: 735-740.

Gettinger, R. D., G. L. Paukstis and W. H. N. Gutzke. 1984. Influence of hydric environment on oxygen consumption by embryonic turtles Chelydra serpentina and Trionyx spiniferus. Physiological Zoologist 57: 468-473.

Gill, W. and T. Whitaker. 1996. New Zealand Frogs and Reptiles, Auckland, New Zealand, David Bateman Limited. 112 p.

Gutzke, W. H. N. and G. L. Paukstis. 1983. Influence of the hydric environment on sexual differentiation of turtles. Journal of Experimental Zoology 226: 467-469.

Hale, W. G., J. P. Margham and V. A. Saunders. 1995. Collins Dictionary of Biology, Second Edition. Glasgow, Harper Collins Publishers. 656 p.

Hardy, G. S. 1977. The New Zealand Scincidae (Reptilia: Lacertilia): a taxonomic and zoogeographic study. New Zealand Journal of Zoology 4: 221-325.

Harlow, P. S. 2000. Incubation temperature determines hatchling sex in Australian rock dragons (Agamidae: Genus Ctenophorus). Copeia 2000(4): 958-964. 
Hutton, J. M. 1987. Incubation temperatures, sex ratios and sex determination in a population of Nile crocodiles (Crocodylus niloticus). The Journal of Zoology, London 211: 143-155.

Janzen, F. J. 1993. An experimental analysis of natural selection on body size of hatchling turtles. Ecology 74(2): 332-341.

Janzen, F. J. 1995. Experimental evidence for the evolutionary significance of temperature-dependent sex determination. Evolution 49(5): 864-873.

Jayne, B. C. and A. F. Bennett. 1990. Selection on locomotor performance capacity in a natural population of garter snakes. Evolution 44: 1204-1229.

Joanen, T., L. McNease and M. W. J. Ferguson. 1987. The effects of egg incubation temperature on post-hatching growth of American alligators. Pp 533-537. In G. J. W. Webb, S. C. Manolis and P. J. Whitehead (eds.), Wildlife Management: Crocodiles and Alligators. Surry Beatty and Sons Pty Limited, Louisiana.

Miller, K., G. C. Packard and M. J. Packard. 1987. Hydric conditions during incubation influence locomotor performance of hatchling snapping turtles. Journal of Experimental Biology 127: 401-412.

Mittwoch, U. 1996. Sex-determining mechanisms in animals. Trends in Ecology and Evolution 11(2): 63-67.

Morris, K. A., G. C. Packard, T. J. Boardman, G. L. Paukstis and M. J. Packard. 1983. Effect of the hydric environment on growth of embryonic snapping turtles (Chelydra serpentina). Herpetologica 39: 272-285.

Mrosovsky, N. and C. L. Yntema. 1980. Temperature dependence of sexual differentiation in sea turtles: implications for conservation practices. Journal of Herpetology 18: 271-280.

Packard, G. C. and M. J. Packard. 1987. Water relations and nitrogen excretion in embryos of the oviparous snake Coluber constrictor. Copeia 1987: 395-406.

Packard, G. C., M. J. Packard and L. Benigan. 1991. Sexual differentiation, growth, and hatching success by embryonic painted turtles incubated in wet and dry environments at fluctuating temperatures. Herpetologica 47(1): 125-132.

Packard, G. C., M. J. Packard and G. F. Birchard. 1989. Sexual differentiation and hatchling success by painted turtles incubating in different thermal and hydric environments. Herpetologica 45: 385-392.

Packard, G. C. and J. A. Phillips. 1994. The importance of the physical environment for the incubation of reptilian eggs. Pp 195-208. In J. B. Murphy, K. Adler and J. T. Collins (eds.), Captive Management and Conservation of Amphibians and Reptiles. Society for the Study of Amphibians and Reptiles, Ithaca (New York). Contributions to Herpetology, Volume 11.

Packard, M. J., G. C. Packard and T. J. Boardman. 1982. Structure of egg shells and water relations of reptilian eggs. Herpetologica 38: 136-155. 
Patterson, G. B. and C. H. Daugherty. 1995. Reinstatement of the genus Oligosoma (Reptilia: Lacertilia: Scincidae). Journal of the Royal Society of New Zealand 25: 327-331.

Plummer, M. V., C. E. Shadrix and R. C. Cox. 1994. Thermal limits of incubation in embryos of softshell turtles (Apalone mutica). Chelonian Conservation and Biology 1(2): 141-144.

Robb, J. 1973. Reptiles and Amphibians. Pp 285-303. In G. R. Williams (eds.), The Natural History of New Zealand - an Ecological Survey. A. H. \& A. W. Reed Ltd., Wellington.

Russell, P. J. 1998. Genetics, Fifth Edition. Menlo Park, California, Benjamin/Cummings. 805 p.

Shine, R. 1995. A new hypothesis for the evolution of viviparity in reptiles. The American Naturalist 145(5): 809-823.

Smith, S. A., C. H. Daugherty and M. N. Hutchinson. 2001. Phylogenetic affinities of Oligosoma suteri, New Zealand's only native egg-laying skink, Abstracts of papers presented at the 9th SRARNZ conference, St Arnaud, Nelson Lakes, New Zealand, 2-4 February 2001. New Zealand Journal of Zoology (in press).

Thompson, M. B. 1990. Incubation of eggs of tuatara, Sphenodon punctatus. The Journal of Zoology, London 222: 303-318.

Thoresen, A. C. 1967. Ecological observations on Stanley and Green Islands Mercury Group. Notornis 14(4): 182-200.

Towns, D. R. 1975a. Ecology of the black shore skink, Leiolopisma suteri (Lacertilia: Scincidae), in boulder beach habitats. New Zealand Journal of Zoology 2(4): 389407.

Towns, D. R. 1975b. Reproduction and growth of the black shore skink, Leiolopisma suteri (Lacertilia: Scincidae), in north-eastern New Zealand. New Zealand Journal of Zoology 2(4): 409-423.

Towns, D. R. 1988. A Field Guide to the Lizards of New Zealand, Second Edition. Wellington, Department of Conservation. $28 \mathrm{p}$.

Towns, D. R. and C. H. Daugherty. 1994. Patterns of range contractions and extinctions in the New Zealand herpetofauna following human colonisation. New Zealand Journal of Zoology 21: 325-339.

Towns, D. R. and S. M. Ferreira. 2001. Conservation of New Zealand lizards (Lacertilia: Scincidae) by translocation of small populations. Biological Conservation 98(2): 211-222.

Viets, B. E., M. A. Ewert, L. G. Talent and C. E. Nelson. 1994. Sex-determining mechanisms in squamate reptiles. The Journal of Experimental Zoology 270: 45-56. 
Vinegar, A. 1974. Evolutionary implications of temperature induced anomalies of development in snake embryos. Herpetologica 30: 72-74.

Whitaker, A. H. 1968. Leiolopisma suteri (Boulenger) an oviparous skink in New Zealand. New Zealand Journal of Science 11: 425-432.

Whitaker, A. H. 1973. Lizard populations on islands with and without Polynesian rats, Rattus exulans (Peale). Proceedings of the New Zealand Ecological Society 20(1973): 121-130. 


\section{CHAPTER TWO \\ Incubation regime affects morphology and incubation period but not sex of the egg-laying skink, Oligosoma suteri}

\subsection{Introduction}

The egg-laying skink, Oligosoma suteri, is the only endemic, oviparous lizard species in New Zealand (Whitaker 1968). It is restricted to beaches, mainly on north-eastern offshore islands (Thoresen 1967, Towns 1975a, Whitaker 1968), and nests under large stones at the top of the shore (Towns 1975a). Reptile eggs are affected by incubation conditions, influencing many physiological factors, including incubation period, hatching success, hatchling phenotype and sex (Packard and Phillips 1994). Incubation regime during embryonic development can thus affect the life history, survival and reproductive fitness of individuals, populations and ultimately species of reptiles.

Reptile embryos develop faster at warmer temperatures than cooler temperatures (Packard and Packard 1987), with highest survival at an optimal temperature (Christian 1986, Plummer et al. 1994). Inappropriate incubation temperature may have dire effects on embryos and hatchlings. For example, a constant incubation temperature of $27.5^{\circ} \mathrm{C}$ produces skeletal abnormalities in embryos and hatchlings of the snake Python molurus (Vinegar 1974).

Incubation temperature also affects the sex of many reptiles (Bull 1980, Mittwoch 1996), a phenomenon termed temperature-dependent sex determination (TSD). For example, female tuatara (Sphenodon punctatus) are produced at low $\left(18^{\circ} \mathrm{C}\right)$ incubation temperatures and males at warm $\left(22^{\circ} \mathrm{C}\right)$ temperatures (Cree et al. 1995). To date, TSD has been reported in only one species of skink, the viviparous Australian skink, Eulamprus tympanum (M.B. Thompson pers. comm.). The presence of heteromorphic sex chromosomes in reptiles coincides with genetically determined sex (GSD), and thus a lack of TSD, and is most common in squamates (Bull 1980). 
Water potential of the incubation medium can also affect the physiology of embryo and hatchling reptiles. For example, an increase in moisture content of incubation substrate increases incubation period and size at hatching in the snapping turtle, Chelydra serpentina (Morris et al. 1983).

The aim of this chapter is to investigate the effects of different constant incubation temperatures and water potentials during captive incubation on physiological attributes of $O$. suteri. In particular, I sought to determine the conditions required for successful artificial incubation, focusing on length of incubation, change in egg mass, hatching success, hatchling morphology and sex of hatchlings. 


\subsection{Methods}

\subsubsection{Study area}

Gravid adult females were collected from Green Island (Figure 2.1), a small (3 ha) island in the Mercury Island group, $6 \mathrm{~km}$ East of the Coromandel Peninsula, New Zealand (36³9'S, $175^{\circ} 51^{\prime} \mathrm{E}$, McKenzie 1995, Towns et al. 1990). The island has never had introduced mammalian predators and has remained largely unmodified (Towns et al. 1990), and thus has one of the highest known concentrations of O. suteri in New Zealand (Whitaker 1973). The Mercury Islands receive high but variable annual rainfall and experience warm humid summers, reaching $25^{\circ} \mathrm{C}$ or greater for 10 20 days of the year, with a mean annual temperature of $14-15^{\circ} \mathrm{C}$ (Kirkpatrick 1999).

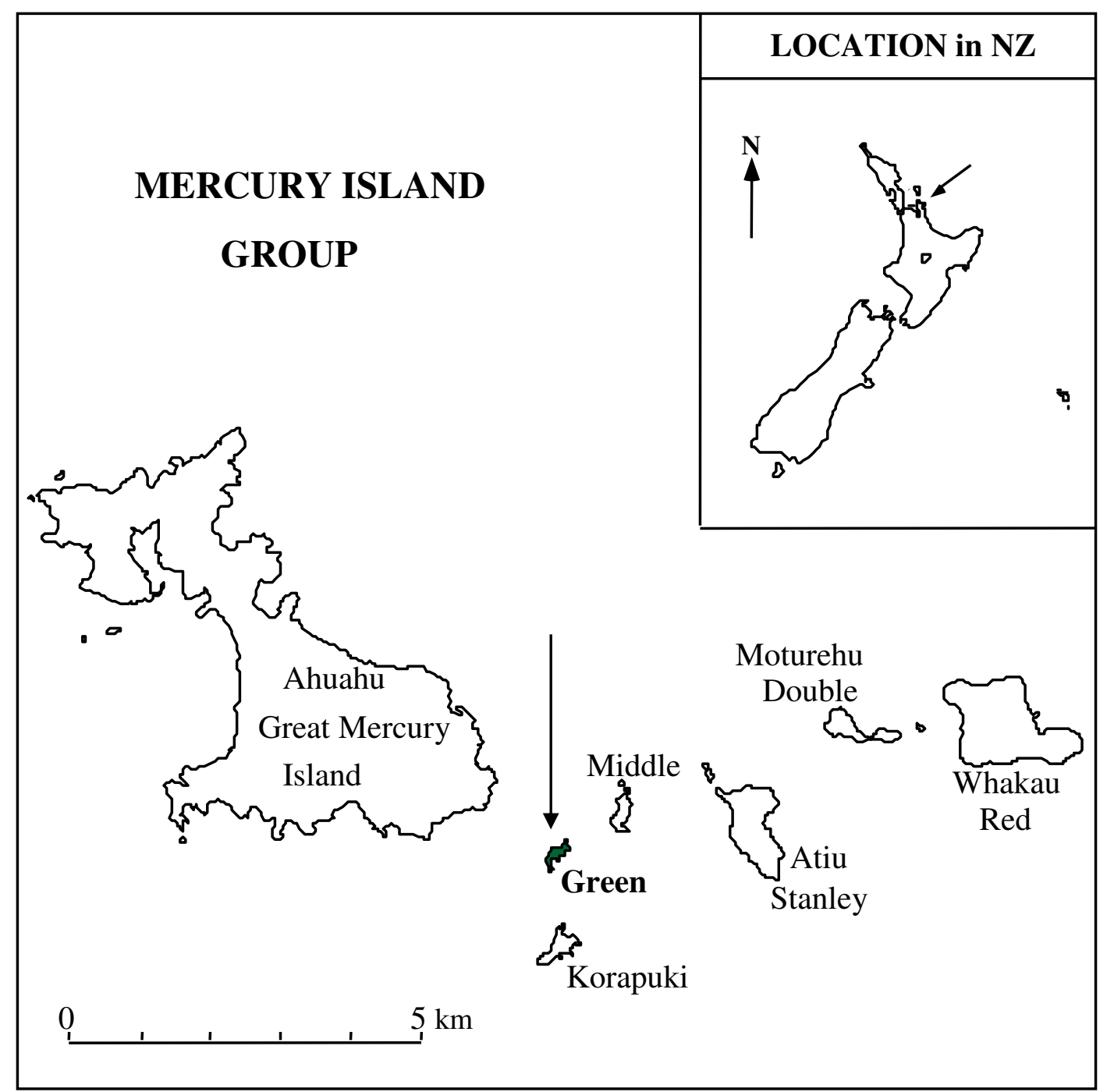

Figure 2.1 Location of the Mercury Island Group in New Zealand (insert) and Green Island (shaded) within the Mercury Island Group. 


\subsubsection{Collection of gravid females}

Fifty eight gravid females were collected, using pitfall traps and night searches, between 30 November and 7 December 1999. The traps consisted of 30 white paint pails (4 L), 6 brown buckets (5 L), and 10 metal paint tins (4 L) and were set just above high tide amongst seaweed mats on the boulder beach. Square plastic covers $(5 \times 250 \mathrm{x}$ $250 \mathrm{~mm}$ ) were erected $30 \mathrm{~mm}$ above traps to protect skinks from predators, such as tuatara (Sphenodon punctatus punctatus). Traps were baited with a seafood based cat food, canned corned beef or fresh salami, and were set half an hour before dusk each evening. Traps were cleared of lizards each morning between 0630 and $0700 \mathrm{~h}$ to ensure they did not overheat in the sun.

Females were identified as gravid by the observation of eggs, visible through the abdominal wall as lighter marks. They were weighed using a Pesola ${ }^{\mathrm{TM}}$ balance $\pm 0.1 \mathrm{~g}$, and snout-vent length (SVL) and vent-tail length (VTL) were measured to $0.5 \mathrm{~mm}$ with a clear, $300 \mathrm{~mm}$ plastic ruler. Individuals without natural toe loss were uniquely marked by toe-clipping (Appendix I) for identification. Females were kept in ventilated $2 \mathrm{~L}$ plastic containers (two per container), with soil and leaves for substrate, and transported to Victoria University of Wellington (VUW) in cloth bags (two per bag).

\subsubsection{Husbandry}

Females were individually housed in identical conditions in transparent plastic boxes $\left(\right.$ New Ocean $^{\text {TM }}$ Plastic No. 838, $215 \times 330 \times 110$ mm, 7 L) with a square of wire mesh $(165 \times 120 \mathrm{~mm})$ on the lid allowing airflow. Boxes contained moist, non-fertilised potting mix in the bottom (at least $20 \mathrm{~mm}$ deep), pieces of pine (Pinus radiata) bark for shelter, and water provided ad libitum in a round plastic bowl $(30 \mathrm{~mm}$ deep, $70 \mathrm{~mm}$ diameter). To allow for behavioural thermoregulation, skinks had a choice of temperatures, ranging from room temperature $\left(>14.5^{\circ} \mathrm{C}\right)$ to $30^{\circ} \mathrm{C}$ (provided by a strip heater along the back of each box). The boxes were stacked on metal shelves with simulated natural lighting (Duro-test ${ }^{\circledR}$ True-lite $®$ power twist) suspended from the ceiling on a 12L:12D light cycle (lights on at $0600 \mathrm{~h}$ ). Females were fed three times a week on crickets (Teleogryllus commodus), slaters (Porcellio spp.), houseflies (Musca domestica) or blowflies (Family: Calliphoridae), periodically laced with vitamin supplement powder (Villavet calcipup). Enclosures were checked twice daily for eggs 
until all females had oviposited (21/12/1999 to 21/01/2000). The skinks were weighed to $1 \mathrm{mg}$ on a Sartørius top loading balance immediately post-oviposition, after which they were returned to Green Island.

\subsubsection{Incubation of eggs}

One hundred and seventy four eggs from 55 clutches were incubated. The clutches were split, and eggs randomly assigned among three incubation temperatures $\left(18^{\circ} \mathrm{C}\right.$, $22^{\circ} \mathrm{C}$ and $\left.26^{\circ} \mathrm{C}\right)$ and two water potentials $(-120 \mathrm{kPa}$ and $-270 \mathrm{kPa})$. Each egg was assigned a unique number, written on the top surface with a soft (4B) graphite pencil, to enable maintenance of egg orientation throughout incubation. Conservation and cultural values associated with $O$. suteri, and the areas it inhabits, makes egg collection of this species difficult. Therefore, out of the 214 eggs laid, 38 eggs were contributed to another study outside the scope of this thesis (Stewart, J. R., M. N. Hutchinson and M. B. Thompson, unpub. data), and two eggs were sacrificed immediately after oviposition (Appendix IIa) to enable the embryonic stage at oviposition to be determined. For these studies, eggs from clutches of two, one egg from clutches of four, and two eggs from clutches of five were taken. Thus, three eggs were available from most females for clutch assortment within incubation regimes.

In the absence of data from natural nests, incubation temperatures were selected over a range of temperatures to which eggs were predicted to be exposed in the wild. Incubation temperatures were accurate to $\pm 0.3^{\circ} \mathrm{C}$, as recorded using data loggers in the incubators (StowAway TidbiT Temp Logger, Onset ${ }^{\mathrm{TM}}$ Computer Corporation, Massachusetts, USA).

The eggs were initially placed in separate plastic cups (50 mm deep x $55 \mathrm{~mm}$ diameter) and half buried in vermiculite. The cups were completely covered with transparent cling-wrap to prevent moisture loss. However, when some eggs began to dehydrate in the cups (12 January 2000), the eggs were reassigned to random positions in 2 L plastic containers ( 8 to 13 eggs/container and 2 to 4 containers/treatment). The location of egg boxes (and cups) was altered daily to compensate for possible temperature gradients within incubators. 
Water potential of the medium grade vermiculite used as an incubation medium was achieved by mixing $100 \mathrm{~g}$ of vermiculite with $96.4 \mathrm{ml}(-120 \mathrm{kPa})$ or $32.6 \mathrm{ml}(-270 \mathrm{kPa})$ of water. Two different water potentials were chosen, as eggs of oviparous squamate reptiles usually have thin flexible shells with little resistance to water movement from the surrounding environment, and are thus influenced by moisture availability (Packard et al. 1982). The egg box containing moist vermiculite was weighed without eggs or a lid, and this weight maintained by addition of distilled water every seven days to compensate for small losses from the container and uptake by the eggs. Eggs were weighed weekly to $1 \mathrm{mg}$ on a Sartørius top loading balance and a sub-sample candled (by shining a cool heat, fibre-optic light source; Schott Mainz ${ }^{\mathrm{TM}}$, KL 150B) to observe viability and development of the embryos.

A $\mathrm{Q}_{10}$ for incubation period was calculated from incubation periods at $22^{\circ} \mathrm{C}$ and $26^{\circ} \mathrm{C}$ (2.46) and used to predict the incubation period for $18^{\circ} \mathrm{C}$ eggs (105 days). When the $18^{\circ} \mathrm{C}$ eggs had not hatched 30 days after the predicted day of hatching ( $4^{\text {th }}$ April 2000), three eggs were dissected and the embryos staged. The rest were randomly assigned to either $18^{\circ} \mathrm{C}$ or $22^{\circ} \mathrm{C}$ ( $4^{\text {th }}$ May 2000) for the remainder of incubation (10 to 29 days).

\subsubsection{Sex identification of juveniles}

After hatching, juveniles were held in a $2 \mathrm{~L}$ plastic container for three days before sex identification was attempted by eversion of hemipenes (Harlow 1996). Identification of sex involved holding the skink in one hand with a thumb on its pelvis, and rolling the end of a small plastic paintbrush up its tail (Figure 2.2). I found this method to be easier than a process described by Harlow (1996), and it had the added benefit of not requiring two people or cooling of the juvenile beforehand. As there can be uncertainty involved in diagnosis of females simply from negative results (DeNardo 1996), gonadal sex was confirmed with histological analysis of animals that died naturally. As this species is protected in New Zealand, juveniles could not be sacrificed for my research.

Fully developed embryos and juveniles that died were fixed, embedded, sectioned to $7 \mu \mathrm{m}$, stained (Humason 1979) and mounted (Methods in Appendix II). The skink sections were observed under a compound microscope (Zeiss); the right and left sides of animals were viewed from the dorsal surface. 


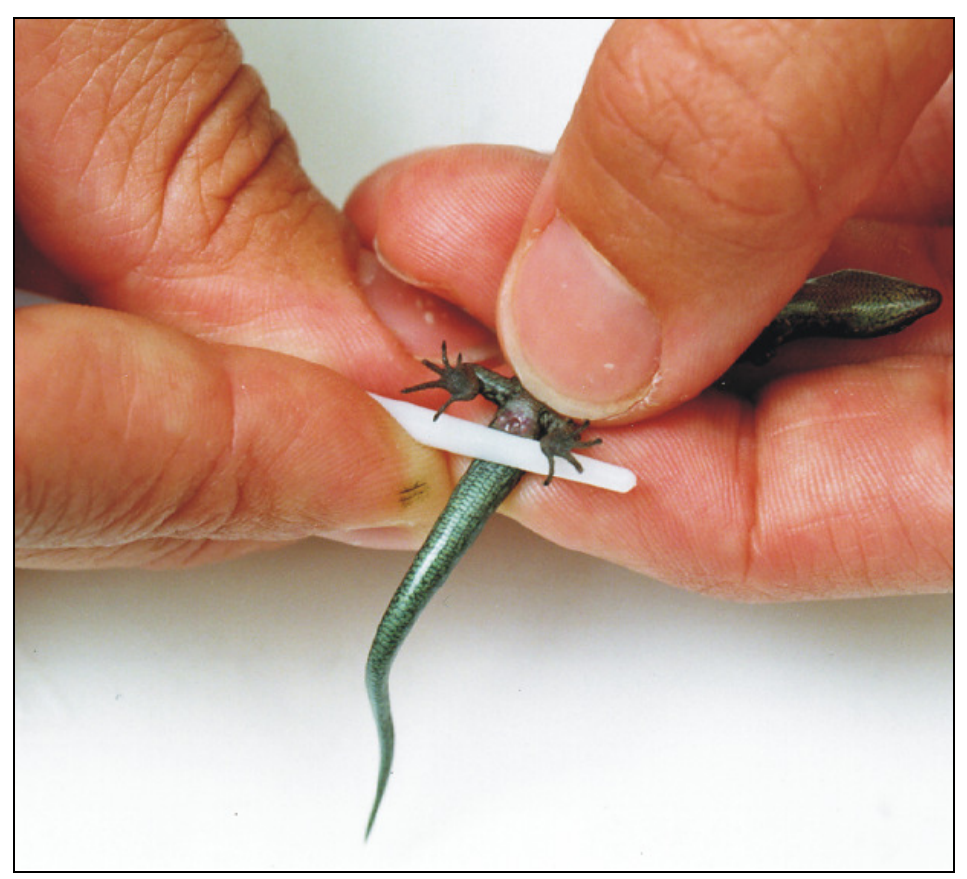

Figure 2.2 Method of hemipene eversion used in this experiment.

\subsubsection{Data analysis}

Data were analysed using the statistics packages SYSTAT, SPSS and S-plus. All data were tested for normality using exploratory analyses on the statistics program SPSS, and statistical significance was assumed at $\mathrm{p}<0.05$. Data are expressed as mean \pm standard error (SE), unless otherwise stated.

\subsubsection{Eggs}

Clutch effects were not investigated as all clutches had five eggs or fewer, too few for powerful statistical tests (pers. comm. Edith Hodgen). However, the effect of maternal size (SVL) on mean initial egg mass of all eggs in a clutch (mean initial egg mass) and number of eggs in a clutch (clutch size) was tested using ANOVA on SPSS.

Only those eggs that hatched without assistance (versus those cut open) were used for incubation analyses. The effect of changing from cups to boxes during incubation versus only incubating in boxes was tested by a MANOVA, with a nested water potential and temperature design, on SYSTAT. The effect of both incubation treatments and initial egg mass on incubation period was assessed using a univariate general linear model (GLM) on SPSS with incubation treatments as independent factors, days of incubation as the dependent variable, and initial egg mass as a covariate. 
The effect of incubation regime and initial egg mass on change in egg mass over the incubation period was assessed using ANOVA on SPSS, with incubation treatments as independent factors, change in egg mass as the dependent variable and initial egg mass as a covariate. The effect of incubation regime and initial egg mass on hatching success was assessed using logistic regression models on S-plus with the independent factors initial egg mass and incubation treatments (incubation temperature and water potential as categorical data), and the dependent variable of probability of hatching ( $1=$ hatched, $0=$ did not hatch). Akaike information criteria were used to determine the best-fit model and which independent factors did not contribute to hatching success (McCallum 2000). Chi-squared tests $\left(\chi^{2}\right)$ were used to compare models. As $95 \%$ confidence intervals can take the upper limit of probability above one, and probability of hatching cannot be greater than one ( 1 = hatched), $95 \%$ profile likelihood intervals were used.

\subsubsection{Sex ratio}

Sex ratios were analysed for deviation from a 50:50 ratio for each incubation treatment, using the $\chi^{2}$ distribution (Sokal and Rohlf 1981). 


\subsection{Results}

There were no significant differences in incubation period and hatching success between individuals incubated only at $18^{\circ} \mathrm{C}$ and those that had incubation temperature increased to $22^{\circ} \mathrm{C}$ near the end of incubation. For example, incubation period for $18^{\circ} \mathrm{C}$ only was $140.0 \pm 1.9$ days and for those increased to $22^{\circ} \mathrm{C}$ for the final 10 to 29 days of incubation it was $136.9 \pm 2.1$ days. Therefore, all parameters for these individuals were combined for further analyses. Similarly, there was no significant influence of changing from cups to boxes and no box affect, which allowed for removal of these parameters for the remainder of the analyses. Results from all statistical tests, significant or otherwise, are presented in Appendix IIIa.

\subsubsection{Eggs}

The 58 females laid a total of 214 eggs, with clutch sizes varying from two to five eggs (mean $3.6 \pm 0.1$ ). Between 27 and 31 eggs were assigned to each incubation regime, two eggs were dissected to determine the embryonic stage at oviposition, and the remaining 38 eggs went to the study described in section 2.2.4. Egg fate was mainly influenced by incubation temperature, with some fully developed embryos failing to hatch at $18^{\circ} \mathrm{C}$ (Table 2.1). Incubation by the cup method caused dehydration, especially at the warmest, driest incubation regime, whereas no eggs dehydrated in the $2 \mathrm{~L}$ plastic containers. No dehydrated eggs hatched successfully.

Table 2.1 Distribution of eggs amongst the incubation treatments, detailing eggs that fail to develop, eggs that fully develop and eggs that hatch $(\mathrm{WP}=$ water potential, $\mathrm{T}=$ temperature).

\begin{tabular}{|c|c|c|c|c|c|c|}
\hline \multirow{2}{*}{$\begin{array}{l}\text { WP } \\
(\mathbf{k P a})\end{array}$} & \multirow{2}{*}{$\begin{array}{c}\mathbf{T} \\
\left({ }^{\circ} \mathbf{C}\right)\end{array}$} & \multirow{2}{*}{$\begin{array}{c}\text { Egg } \\
\text { Distribution }\end{array}$} & \multicolumn{2}{|c|}{ Egg Failed } & \multirow{2}{*}{$\begin{array}{c}\text { Full } \\
\text { Development }\end{array}$} & \multirow{2}{*}{$\begin{array}{c}\text { Hatched } \\
\text { Successfully }\end{array}$} \\
\hline & & & Mouldy & Dehydrated & & \\
\hline \multirow[t]{3}{*}{-120} & 18 & 27 & 2 & 1 & 24 & 19 \\
\hline & 22 & 27 & 1 & 1 & 25 & 25 \\
\hline & 26 & 33 & 4 & 3 & 26 & 26 \\
\hline \multirow[t]{3}{*}{-270} & 18 & 28 & 0 & 0 & 28 & 18 \\
\hline & 22 & 28 & 1 & 2 & 25 & 25 \\
\hline & 26 & 31 & 1 & 7 & 23 & 23 \\
\hline \multicolumn{2}{|c|}{ Total } & 174 & 9 & 14 & 151 & 135 \\
\hline
\end{tabular}


The two eggs dissected at laying contained stage 32 embryos, according to the staging series for Lacerta vivipara (Porter 1972). Paddles were distinctly differentiated on each limb, the eye was pigmented and prominent, and a distinct outline of the parietal region and genitalia was apparent (Figure 2.3).

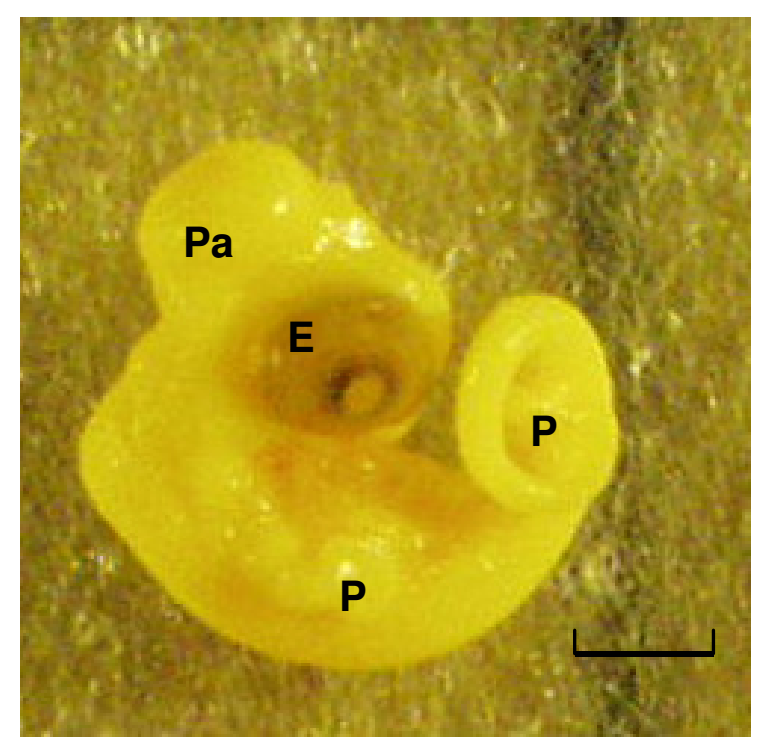

Figure 2.3 O. suteri embryo present in egg at oviposition, stage $32(\mathrm{E}=$ eye, $\mathrm{P}=$ paddle, $\mathrm{Pa}=$ parietal region - genitalia are behind tail). Scale bar is $1 \mathrm{~mm}$.

The size (SVL) of the mother had no effect on mean egg mass of the clutch $(\mathrm{F}=0.827$, $\mathrm{df}=1, \mathrm{p}=0.367)$, but did have a statistical effect on clutch size $(\mathrm{F}=5.981, \mathrm{df}=3$, $p=0.001$ ), with females that oviposited five eggs significantly larger than those that oviposited two to four eggs (Table 2.2). Clutch size was not correlated with mean egg mass of the clutch $(\mathrm{F}=1.085, \mathrm{df}=3, \mathrm{p}=0.363)$.

Table 2.2 Mean maternal snout-vent length (SVL) and egg mass for each clutch size.

\begin{tabular}{|c|c|c|c|}
\hline Clutch Size & $\begin{array}{c}\text { Mean SVL } \\
\pm \text { SE }(\mathbf{m m})\end{array}$ & $\begin{array}{c}\text { Mean Egg Mass } \\
\pm \mathbf{S E}(\mathbf{g})\end{array}$ & No. Clutches \\
\hline 2 & $96.7 \pm 1.2$ & $1.042 \pm 0.08$ & 3 \\
3 & $94.3 \pm 0.6$ & $0.935 \pm 0.02$ & 20 \\
4 & $97.3 \pm 0.6$ & $0.944 \pm 0.02$ & 31 \\
5 & $101.0 \pm 2.0$ & $0.906 \pm 0.06$ & 4 \\
\hline
\end{tabular}


Incubation period was affected by temperature $(\mathrm{F}=5715.287, \mathrm{df}=2, \mathrm{p}<0.001)$, but not water potential $(\mathrm{F}=0.497, \mathrm{df}=1, \mathrm{p}=0.482)$, initial egg mass $(\mathrm{F}=0.577, \mathrm{df}=1$, $p=0.449$ ), or any combination of these three factors. Eggs took longer to hatch at cooler temperatures; eggs at $18^{\circ} \mathrm{C}$ had the longest incubation period (mean $=137.9 \pm$ 0.9 days). Eggs at the two warmer temperatures $\left(22^{\circ} \mathrm{C}\right.$ and $\left.26^{\circ} \mathrm{C}\right)$ took, on average, $73.8 \pm 0.5$ days and $51.5 \pm 0.3$ days to hatch, respectively (Figure 2.4).

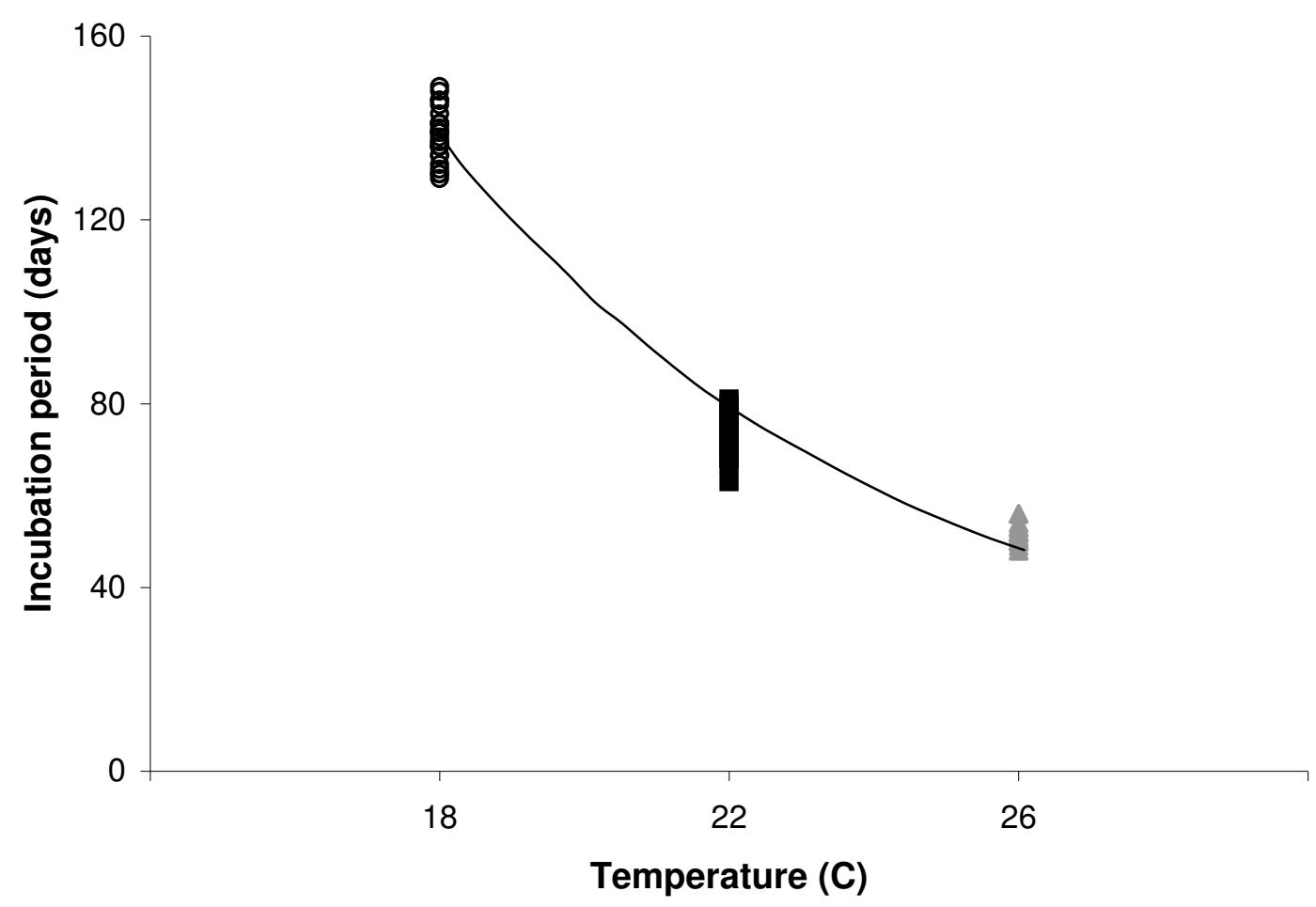

Figure 2.4 Incubation period (days) for each incubation temperature $\left(\circ=18^{\circ} \mathrm{C}, \boldsymbol{\square}=22^{\circ} \mathrm{C}\right.$, $\Delta=26^{\circ} \mathrm{C}$ ). Note that $18^{\circ} \mathrm{C}$ includes individuals that completed the last part of incubation at either $18^{\circ} \mathrm{C}$ or $22^{\circ} \mathrm{C}$. The quadratic equation best fitting the data is $y=1.3181 x^{2}-68.843 x+950.37\left(R^{2}=0.9889\right)$.

Change in egg mass during incubation was significantly influenced by incubation temperature $(\mathrm{F}=8.551, \mathrm{df}=2, \mathrm{p}<0.001$, Figure 2.5$)$, water potential $(\mathrm{F}=34.150$, $\mathrm{df}=1, \mathrm{p}<0.001)$ and initial egg mass $(\mathrm{F}=5.819, \mathrm{df}=1, \mathrm{p}=0.017)$, but not by a combination of the two incubation factors $(F=1.667, \mathrm{df}=2, \mathrm{p}=0.192)$. Change in egg mass was greater for incubation at $18^{\circ} \mathrm{C}$, the wetter water potential $(-120 \mathrm{kPa})$ and larger eggs. 


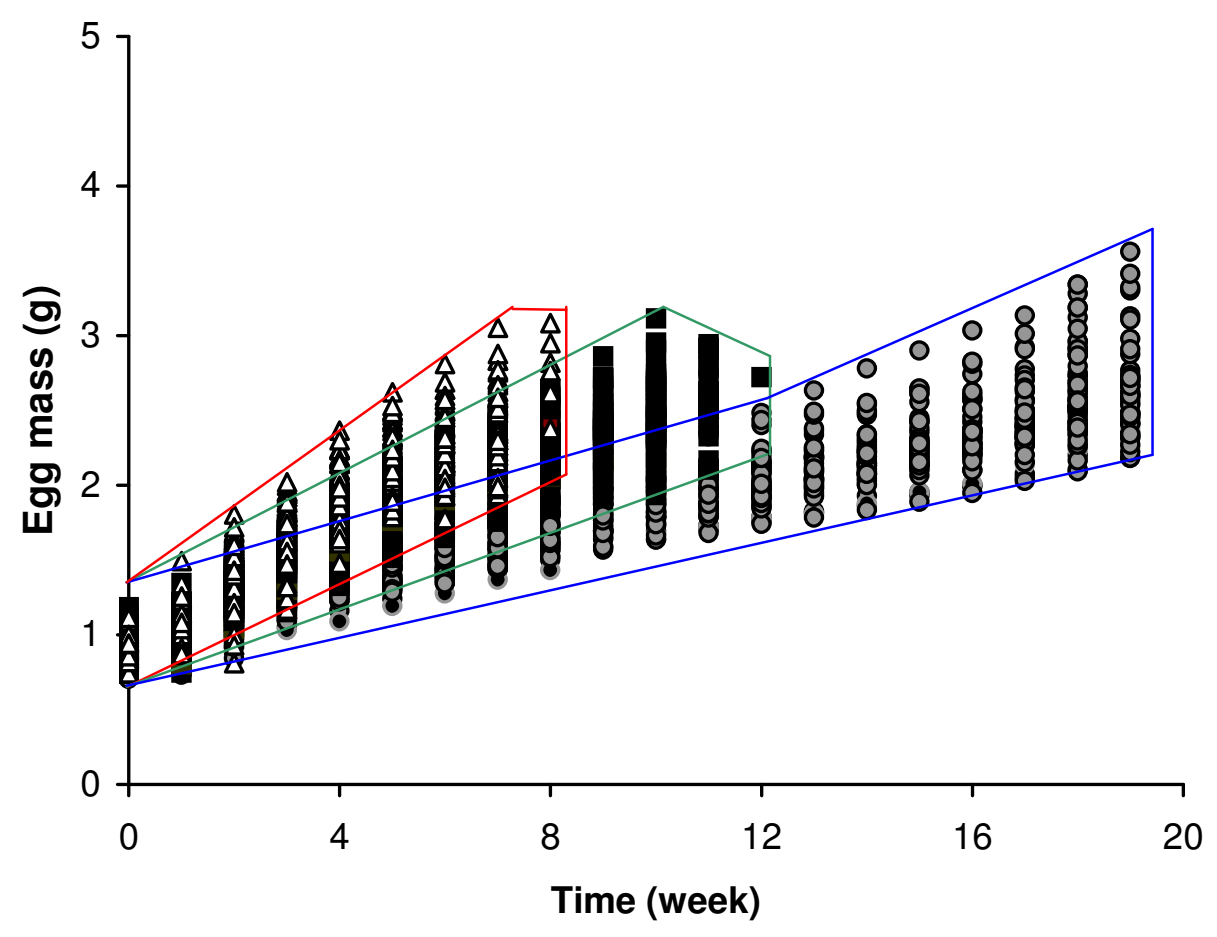

Figure 2.5 Change in egg mass over incubation period for each incubation temperature. The red line outlines $26^{\circ} \mathrm{C}(\Delta)$, green $22^{\circ} \mathrm{C}(\bullet)$ and blue $18^{\circ} \mathrm{C}(\bullet)$. Note that $18^{\circ} \mathrm{C}$ includes individuals that completed the last part of incubation at either $18^{\circ} \mathrm{C}$ or $22^{\circ} \mathrm{C}$.

\subsubsection{Hatching success and hatchling morphology}

Hatching success was significantly influenced by incubation temperature $\left(\chi^{2}=8.020\right.$, $\mathrm{df}=171,2, \mathrm{p}=0.018)$ with higher hatching success occurring at the two warmer $\left(22^{\circ} \mathrm{C}\right.$ and $26^{\circ} \mathrm{C}$ ) incubation temperatures (Figure 2.6). Hatching success was not significantly influenced by water potential $\left(\chi^{2}=0.828, \mathrm{df}=172,1, \mathrm{p}=0.363\right)$, initial egg mass $\left(\chi^{2}=0.983, \mathrm{df}=172,1, \mathrm{p}=0.322\right)$, or any combination of these three factors.

Hatchlings from $22^{\circ} \mathrm{C}$ and $26^{\circ} \mathrm{C}$ had similar patterning to wild individuals (grey-brown colour with indistinct spots on the dorsal surface and flanks), straight tails and correctly orientated feet and legs. Hatchlings incubated at $18^{\circ} \mathrm{C}(\mathrm{n}=37)$ had uniform, darkbrown colouration and physical abnormalities; tails were bent $(100 \%, \mathrm{n}=37)$, front feet paddle-like $(91 \%, \mathrm{n}=34)$, the rear feet flattened $(91 \%, \mathrm{n}=34)$, and sometimes the rear legs were also bent backwards at the ankles $(11 \%, \mathrm{n}=4$, Figure 2.7$)$. 


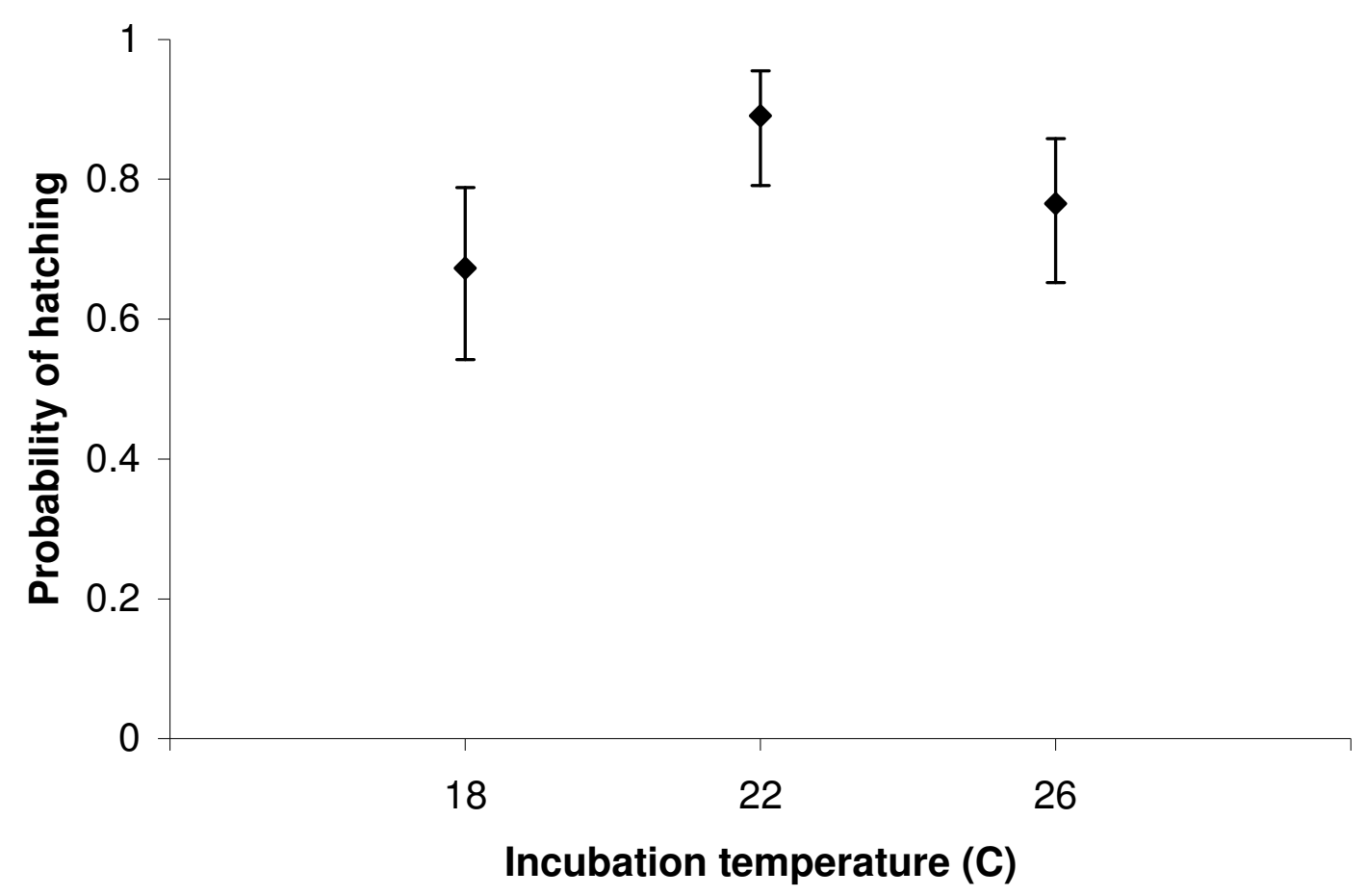

Figure 2.6 Probability of hatching at each incubation temperature \pm profile likelihood intervals. Note that $18^{\circ} \mathrm{C}$ includes individuals that completed the last part of incubation at either $18^{\circ} \mathrm{C}$ or $22^{\circ} \mathrm{C}$.

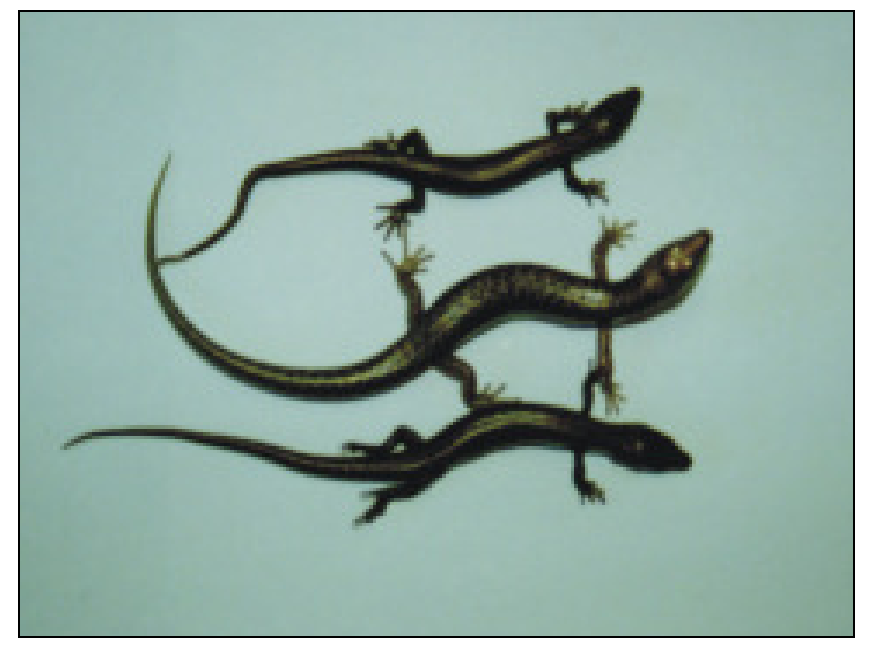

Figure 2.7 Abnormal phenotype of juveniles incubated at $18^{\circ} \mathrm{C}$ (upper and lower skinks), showing uniform, dark-brown colouration, bent tails, paddle-like front feet and flattened rear feet, compared to the normal phenotype of a $26^{\circ} \mathrm{C}$ (centre skink) incubated juvenile. 


\subsubsection{Identification of hatchling sex}

Hemipene eversion allowed hatchlings to be classified into four groups (Tables 2.3a and $b$ ). Males $(n=77)$ had large white projections (Figure 2.8a), while putative males $(\mathrm{n}=48)$ had smaller pink projections (Figure $2.8 \mathrm{~b})$. Females $(\mathrm{n}=5)$ had no projections visible (Figure $2.8 \mathrm{c})$, whereas putative females $(\mathrm{n}=21)$ had very small, pink projections (Figure 2.8d).

(a)

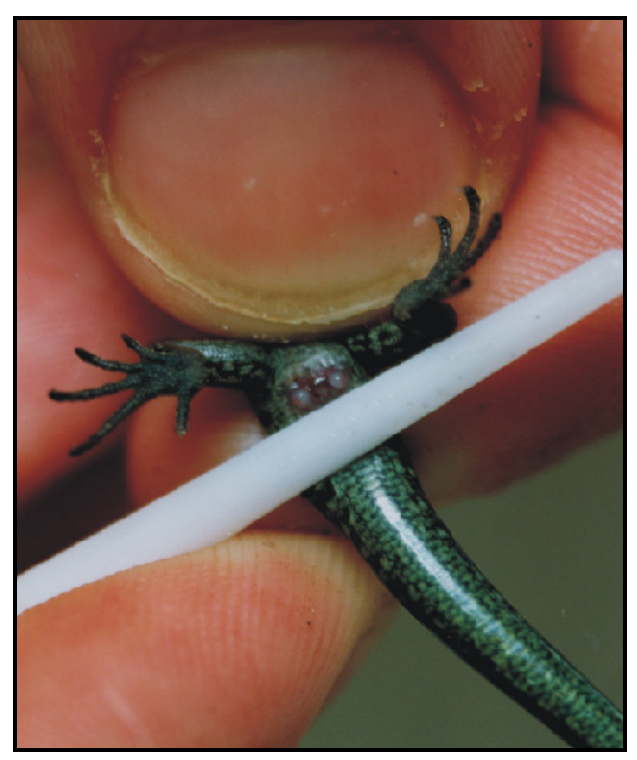

(c)

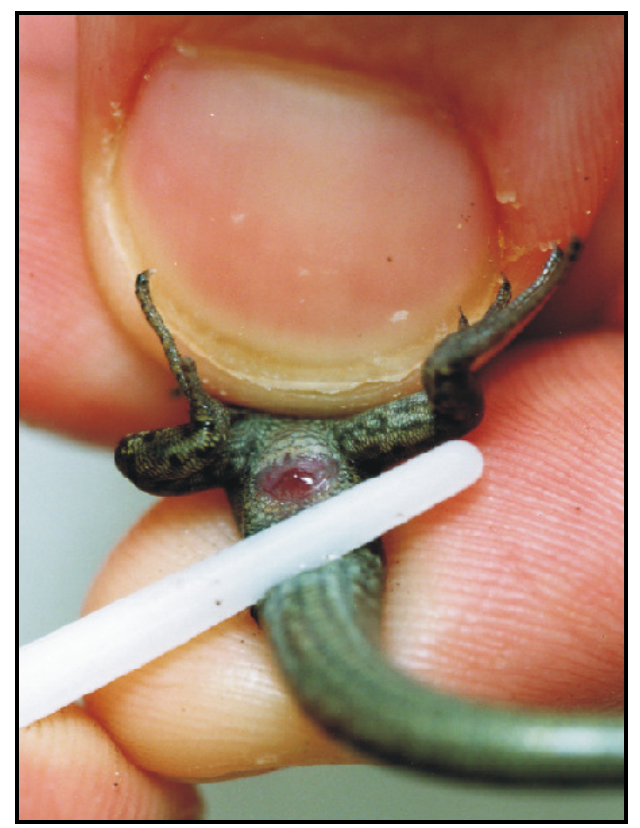

(b)

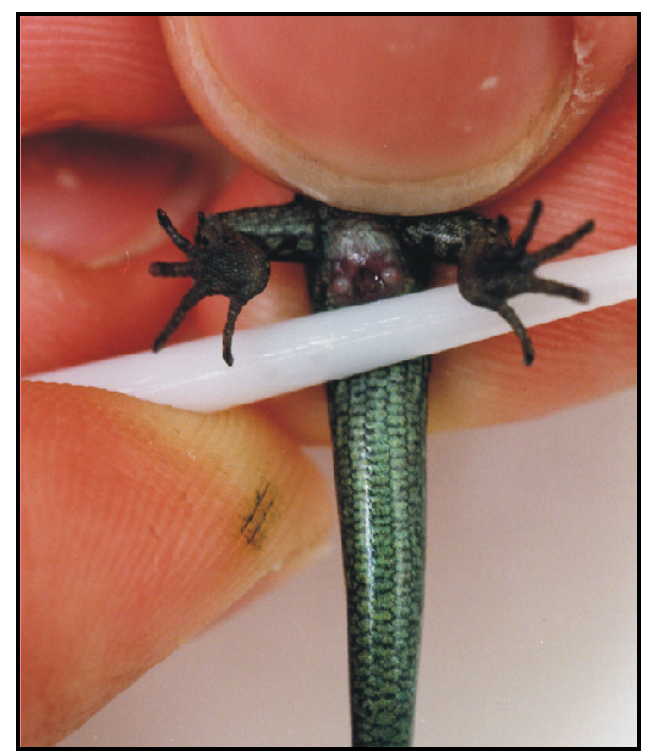

(d)

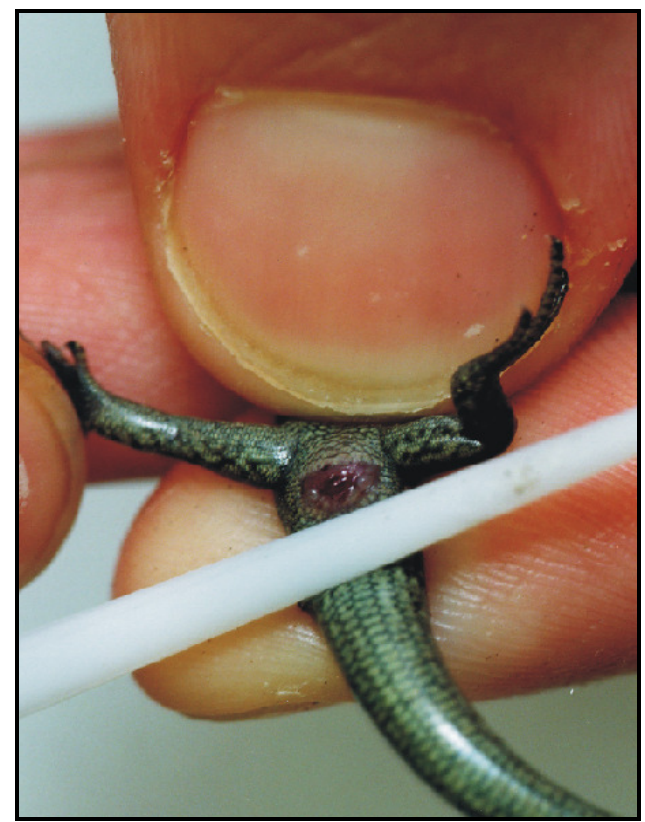

Figure 2.8 Cloacal area of juvenile $O$. suteri during hemipene eversion: (a) male, (b) putative male, (c) female, (d) putative female. 
Table 2.3 Number of individuals in each morphological class with corresponding morphological traits for each incubation temperature (a) and water potential (b).

(a)

\begin{tabular}{|l|l|ccc|c|}
\hline \multicolumn{1}{|c|}{$\begin{array}{c}\text { Initial } \\
\text { Morphological }\end{array}$} & \multicolumn{3}{|c|}{ Temperature $\left({ }^{\circ} \mathbf{C}\right)$} & \multirow{2}{*}{ Total } \\
\cline { 3 - 5 } Classification & \multicolumn{1}{|c|}{$\begin{array}{c}\text { Trait } \\
\text { Male }\end{array}$} & $\mathbf{1 8}$ & $\mathbf{2 2}$ & $\mathbf{2 6}$ & \\
\hline Putative male & Large, white & 27 & 25 & 25 & 77 \\
Female & Small, pink & 17 & 17 & 14 & 48 \\
Putative female & None & 0 & 2 & 3 & 5 \\
& Very small, pink & 8 & 6 & 7 & 21 \\
\hline
\end{tabular}

(b)

\begin{tabular}{|c|c|c|c|c|}
\hline \multirow{2}{*}{$\begin{array}{c}\text { Initial } \\
\text { Morphological } \\
\text { Classification }\end{array}$} & \multirow[b]{2}{*}{$\begin{array}{c}\text { Morphological } \\
\text { Trait }\end{array}$} & \multicolumn{2}{|c|}{ Water Potential (kPa) } & \multirow{2}{*}{ Total } \\
\hline & & -120 & -270 & \\
\hline Male & Large, white & 37 & 40 & 77 \\
\hline Putative male & Small, pink & 25 & 23 & 48 \\
\hline Female & None & 2 & 3 & 5 \\
\hline Putative female & Very small, pink & 11 & 10 & 21 \\
\hline
\end{tabular}

Histological examination showed that all individuals with large white projections had testes; those with small pink, very small pink or no projections had ovaries. As a result, all putative males and putative females defined by eversion of hemipenes were reassigned as females. Among the 21 individuals that had their gender verified by histology, all were diagnosed correctly. Gonad shape was not a good predictor of sex, but cell placement and cell characteristics were.

\section{Ovary characteristics}

Most females possessed two ovaries and two müllerian ducts (Figure 2.9a), and lacked any detectable male characteristics. A müllerian duct was not detected in one female on the right side and in a second female on the left; both females had two ovaries. One female lacked an ovary on the left side but still had a müllerian duct; the mesenephric kidney on the left side was also small. All ovaries had large lacunae in the medulla and 
a well-developed cortex (Figure 2.9b) and naked oocytes were present in some older individuals. The right ovary was anterior to the left in all specimens.

(a)

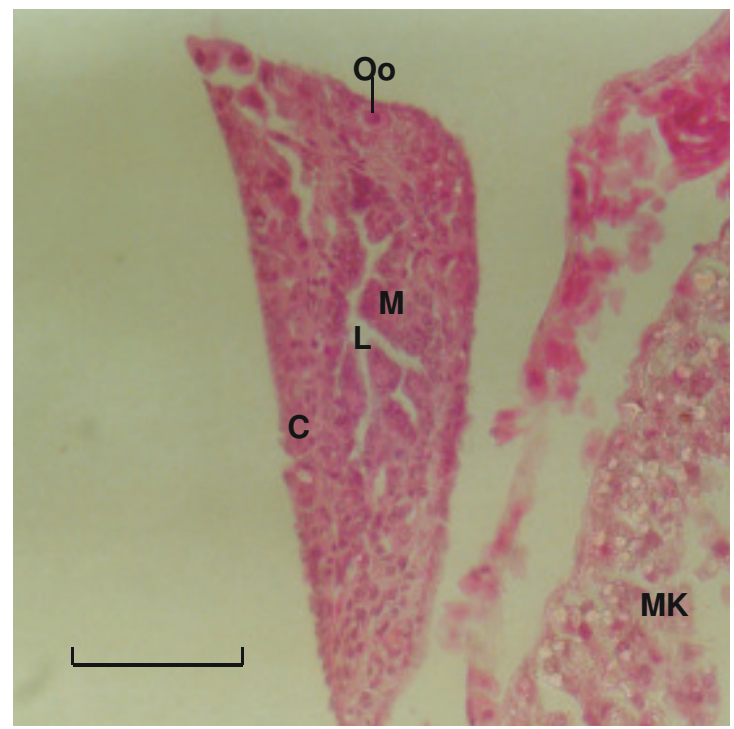

(b)

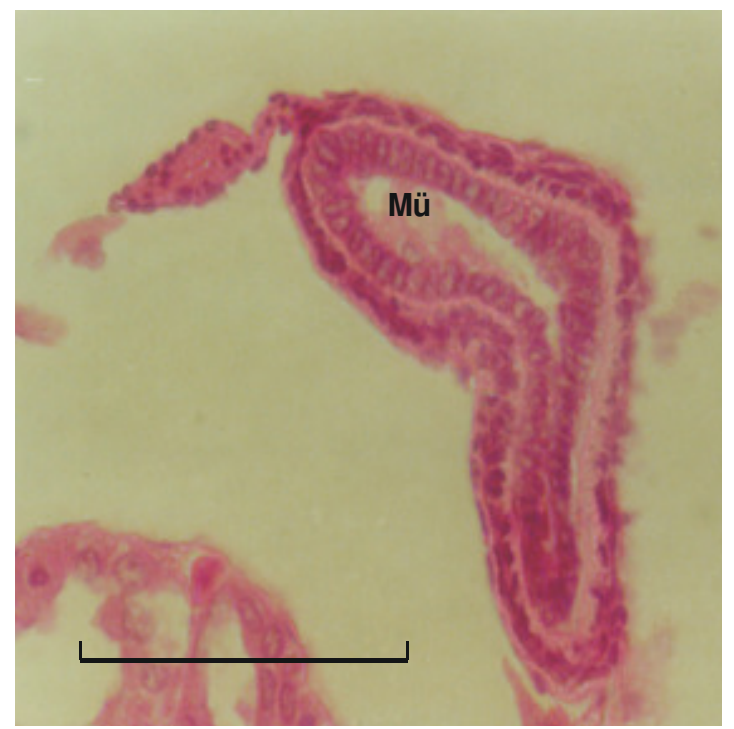

Figure 2.9 Transverse sections of female gonad characteristics in juvenile O. suteri: (a) ovary, (b) müllerian duct. ( $\mathrm{C}=$ cortex, $\mathrm{L}=$ lacunae, $\mathrm{M}=$ medulla, $\mathrm{MK}=$ mesenephric kidney, Mü $=$ müllerian duct, Oo = oocyte). Scale bars are $50 \mu \mathrm{m}$.

\section{Testis characteristics}

All males possessed two testes and lacked any discernible female characteristics. The right testis was anterior to the left testis in all specimens. Most testes had a relatively well-developed medulla, with developing tubules and some germ cells present (Figure 2.10a). The cortex was mostly poorly developed. A wolffian duct could only be located in one male (Figure 2.10b).

\subsubsection{Sex ratio}

Sex ratio did not deviate significantly from 50:50 (Table 2.4) at any incubation temperature $\left(\chi^{2}=0.087, \mathrm{df}=2, \chi^{2}\right.$ statistic $\left.=5.991\right)$ or water potential $\left(\chi^{2}=0.241, \mathrm{df}\right.$ $=1, \chi^{2}$ statistic $\left.=3.841\right)$. Sixty nine percent of clutches produced both male and female hatchlings. 
(a)

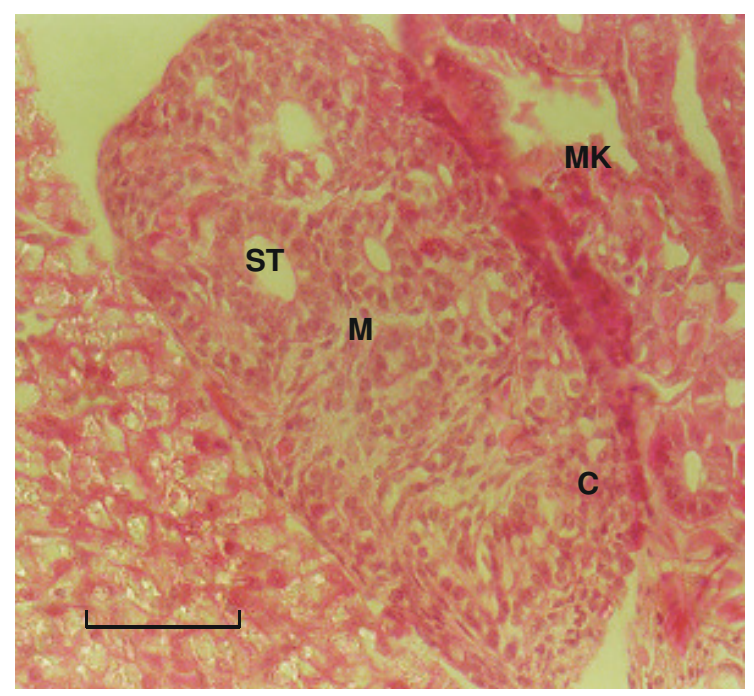

(b)

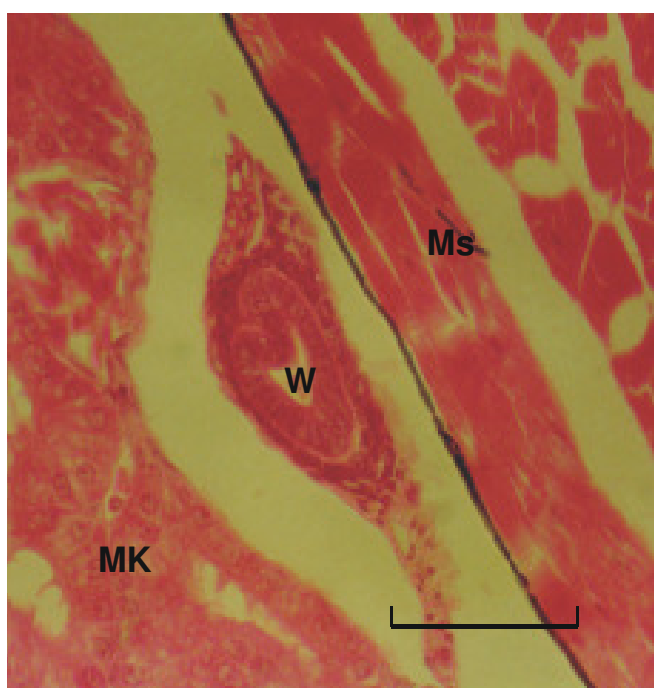

Figure 2.10 Transverse sections of male gonad characteristics in O. suteri; (a) testis, (b) wolffian duct. $(\mathrm{C}=$ cortex, $\mathrm{M}=$ medulla, $\mathrm{MK}=$ mesenephric kidney, $\mathrm{Ms}=$ muscle, $\mathrm{ST}=$ seminiferous tubule, $\mathrm{W}=$ wolffian duct). Scale bars are $50 \mu \mathrm{m}$.

Table 2.4 Number of males and females from each incubation regime.

\begin{tabular}{|c|c|c|c|}
\hline & & $\begin{array}{l}\text { No. Males } \\
(\%)\end{array}$ & $\begin{array}{c}\text { No. Females } \\
(\%)\end{array}$ \\
\hline & 18 & $27(52)$ & $25(48)$ \\
\hline Temperature & 22 & $25(50)$ & $25(50)$ \\
\hline & 26 & $25(51)$ & $24(49)$ \\
\hline Water & -120 & $40(51)$ & $38(49)$ \\
\hline $\begin{array}{c}\text { potential } \\
(\mathbf{k P a})\end{array}$ & -270 & $37(51)$ & $36(49)$ \\
\hline & Total & 77 & 74 \\
\hline
\end{tabular}




\subsection{Discussion}

A constant incubation temperature of $18^{\circ} \mathrm{C}$ is not optimal for $O$. suteri egg incubation, but $22^{\circ} \mathrm{C}$ and $26^{\circ} \mathrm{C}$ and water potentials of $-120 \mathrm{kPa}$ and $-270 \mathrm{kPa}$ produce healthy hatchlings. Incubation period increases with decreasing incubation temperature; egg mortality is greatest at $18^{\circ} \mathrm{C}$ and least at $22^{\circ} \mathrm{C}$. Incubation regime and maternal influence do not affect sex of individuals, so sex is probably genetically determined at the chromosomal level.

\subsubsection{Maternal influence}

At oviposition embryos were at stage 32 (Porter 1972). Most oviparous squamates retain eggs in utero for half of the total period of embryonic development, compared with other reptiles, which usually only briefly retain eggs in the oviduct, with the usual stage of laying at 30 (Shine 1983). Thus, O. suteri oviposit 2 stages later than most other squamate reptiles.

No relationship was evident between size of females and mean egg mass, as also occurs in other reptiles, such as the Australian rock dragon Ctenophorus decresii (Harlow 2000). The number of eggs laid in a clutch by many female reptiles increases with the size of the individual, as more room is available in the female for eggs (e.g. tuatara, Cree et al. 1991; European lacertid lizards, in den Bosch and Bout 1998). Larger $O$. suteri females in this study also, on average, produced more eggs, which is in contrast to the findings of Towns (1975b). However, it is important to note that some larger females did have small clutch sizes, which may be due to the amount of resources available to them during vitellogenesis. The presumed trade-off between the number and size of offspring a female produces is a fundamental tenet of life history theory and is a general feature of reptilian reproduction (Sinervo 1990, 1994, Smith and Fretwell 1974). It is generally thought that any given female has limited resources available for each reproductive event and cannot increase the number of offspring (fecundity) without decreasing survival and possible fitness of offspring (Jayne and Bennett 1990, Sinervo and Doughty 1996). 


\subsubsection{Incubation period, eggs and hatching success}

An increase in incubation period as incubation temperature decreases is a common phenomenon in oviparous reptiles (e.g. Angilletta et al. 2000, Jensen 1982, Lang et al. 1989, Lewis-Winokur and Winokur 1995, Thompson 1990). Incubation period of $O$. suteri eggs also increased as temperature decreased, although incubation period is not influenced by the final 10 to 29 days of incubation. The turtle, Chelydra serpentina also has a rate of development during the final weeks of incubation independent of environmental temperature (Ynetma 1978).

Change in egg mass during incubation is influenced by incubation conditions. For example, wetter water potential and cooler temperatures increase mass change in eggs of the painted turtle Chrysemys picta (Gutzke et al. 1987) and bull snake Pituophis melanoleucus (Gutzke and Packard 1987). The same pattern was found in O. suteri, where wetter water potential $(-120 \mathrm{kPa})$ and cooler incubation temperature $\left(18^{\circ} \mathrm{C}\right)$ resulted in overall heavier final egg mass. This is due to more time available during incubation to take up water (Packard and Phillips 1994). Initial egg mass also influenced hatching egg mass, probably due to increased surface area available in larger eggs for water exchange.

Hatching success of $O$. suteri was influenced by incubation temperature. Constant incubation at $18^{\circ} \mathrm{C}$ resulted in low hatching success and physical abnormalities, such as bent tails. Low hatching success at sub-optimal temperatures occurs in other oviparous reptiles, such as Alligator mississippiensis, which develops fully but fails to hatch at $28^{\circ} \mathrm{C}$, and fails to develop at $36^{\circ} \mathrm{C}$ (Lang and Andrews 1994). Physical abnormalities due to low temperature stress also occur in other squamates. For example, the snake Python molurus develops normally at $30.5^{\circ} \mathrm{C}$ and abnormally at $27.5^{\circ} \mathrm{C}$, with deformities such as kinking of the vertebral column occurring (Vinegar 1974). A similar trend is found in the bull snake (Pituophis melanoleucus), where low hatching success occurs at low $\left(22^{\circ} \mathrm{C}\right)$ incubation temperatures and a significantly greater number of abnormalities at high $\left(32^{\circ} \mathrm{C}\right)$ temperatures (Gutzke and Packard 1987). 


\subsubsection{Sex ratio}

The thermosensitive period for sex determination in most reptiles with TSD occurs in the middle third to half of embryonic development (Birchard and Reiber 1995). Embryonic development in $O$. suteri takes five months, with eggs retained in the oviducts for the first two months (Towns 1975b). Thus, part of the thermosensitive period for sex determination occurs within the mother when the sexual characteristics are beginning to form. However, both sexes were present in most clutches, indicating that the mother did not selectively influence embryonic sex before oviposition. Moreover, sex ratio of hatchlings was not significantly different from 50:50 in any incubation regime, so sex was probably genetically determined. In reptiles, genetically determined sex is most common in squamates, especially in skinks (Janzen and Paukstis 1991), with TSD found in only one skink tested to date - the viviparous Australian skink, Eulamprus tympanum (M. B. Thompson pers. comm.).

\subsubsection{Sexual characters}

Reptiles do not possess external genitalia, and many, such as $O$. suteri, lack external secondary sexual dimorphism (DeNardo 1996, Towns 1975b). In snakes and lizards hemipenes are located in the cloaca of males, enabling sex to be determined by manual eversion (DeNardo 1996). There are difficulties associated with hemipene analysis, including diagnosis of females from negative results, and the appearance of glands in some females (Harlow 1996). Thus, the small pink projections from the cloaca in some female juvenile $O$. suteri could be glands.

Gonad shape is usually a helpful determinant in sex identification of reptiles, with testes usually thin and elongate and ovaries ovoid (Fox 1977). The shape of gonads was not helpful in identifying the sex of $O$. suteri individuals. Most specimens available for histological analysis were from embryos or hatchlings under 1 month old, and the gonads were probably still differentiating (Fox 1977). Undetectable müllerian and wolffian ducts were possibly lost during preparation of histological material, which may also explain the individual without a left ovary. It is also possible that the ovary was lacking, as occurs in some other reptiles such as the gecko, Eublepharis macularius (Bull 1987). However, most juveniles that died in this study suffered from external physical abnormalities, and possibly also internal abnormalities, which could also account for missing structures. The position of testes and ovaries (right gonad 
anterior to the left) is consistent with results found by Towns (1975b), and in other lizards (Fox 1977).

\subsubsection{Ecological implications}

Reptilian development, hatching success and hatchling morphology are influenced, often detrimentally, by deviation of incubation temperature from an optimum. Physical abnormalities occur in $O$. suteri individuals incubated at constant $18^{\circ} \mathrm{C}$, which is probably why $O$. suteri have a restricted northern distribution. Current global warming predictions estimate an increase in mean global temperature of $1.4^{\circ} \mathrm{C}$ to $5.8^{\circ} \mathrm{C}$ by 2100 (IPCC 2001), which may increase nest temperatures in some populations to the upper lethal limit. Potentially the mainland populations of $O$. suteri could extend their range southward if global temperatures increase and suitable boulder beach habitats are available. However, data on natural nest temperatures are needed before effects of increased global temperatures can be ascertained.

An increase in global temperature (that does not reach upper lethal limits) could be advantageous, decreasing the incubation period and thus affecting timing of hatchling emergence in the wild. Earlier hatchling emergence would increase the time available to hatchlings for growth before hibernation (May to August, Towns 1975a), which could lower the time until maturity, and thus first reproduction, is reached.

\subsubsection{Conclusion}

The data presented in this chapter confirms that $O$. suteri physiology is influenced by incubation temperature, as is that of all oviparous reptiles, as well as providing a successful captive incubation regime for $O$. suteri. The sex of $O$. suteri is probably genetically determined, as is found in all but one other skink to date (Janzen and Paukstis 1991, M. B. Thompson pers. comm). The population of captively incubated and reared skinks used in this study will be released onto Korapuki Island, as part of the restoration goals for the island. To assess the long-term effects of constant, captive incubation regime on this species, it is important that this population is monitored after release. 


\subsection{References}

Angilletta, M. J. J., R. S. Winters and A. E. Dunham. 2000. Thermal effects on the energetics of lizard embryos: implications for hatchling phenotypes. Ecology 81(11): 2957-2968.

Birchard, G. F. and C. L. Reiber. 1995. Growth, metabolism, and chorioallantoic vascular density of developing snapping turtles (Chelydra serpentina): influence of temperature. Physiological Zoology 68(5): 799-811.

Bull, J. J. 1980. Sex determination in reptiles. The Quarterly Review of Biology 55(1): 3-21.

Bull, J. J. 1987. Temperature-dependent sex determination in reptiles: validity of sex diagnosis in hatchling lizards. Canadian Journal of Zoology 65: 1421-1424.

Christian, K. A. 1986. The effect of cold exposure during incubation of Sceloporus undulatus eggs. Copeia 1986(4): 1012-1014.

Cree, A., C. H. Daugherty, S. F. Schafer and D. Brown. 1991. Nesting and clutch size of tuatara (Sphenodon guntheri) on North Brother Island, Cook Strait. Tuatara 31: 9-16.

Cree, A., M. B. Thompson and C. H. Daugherty. 1995. Tuatara sex determination. Nature 375: 543.

DeNardo, D. 1996. Reproductive Biology. Pp 212-224. In D. R. Mader (eds.), Reptile Medicine and Surgery. W.B. Saunders Company.

Fox, H. 1977. The urinogenital system of reptiles. Pp 1-464. In G. Gans and T. S. Parsons (eds.), Biology of the Reptilia - Morphology E. Academic Press Ltd., London. Volume 6.

Gutzke, W. H. N. and G. C. Packard. 1987. Influence of the hydric and thermal environments on eggs and hatchlings of bull snakes Pituophis melanoleucus. Physiological Zoology 60(1): 9-17.

Gutzke, W. H. N., G. C. Packard, M. J. Packard and T. J. Boardman. 1987. Influence of the hydric and thermal environments on eggs and hatchlings of painted turtles (Chrysemys picta). Herpetologica 43(4): 393-404.

Harlow, P. S. 1996. A harmless technique for sexing hatchling lizards. Herpetological Review 27(2): 71-72.

Harlow, P. S. 2000. Incubation temperature determines hatchling sex in Australian rock dragons (Agamidae: Genus Ctenophorus). Copeia 2000(4): 958-964.

Humason, G. L. 1979. Animal Tissue Techniques. Fourth Edition. San Francisco, W. H. Freeman and Company. $641 \mathrm{p}$. 
in den Bosch, H., A. J. and R. G. Bout. 1998. Relationships between maternal size, egg size, clutch size, and hatchling size in European Lacertid lizards. Journal of Herpetology 32(3): 410-417.

IPCC. 2001. Climate Change 2001: the Scientific Basis. Intergovernmental Panel on Climate Change, Cambridge University Press. (in press).

Janzen, F. J. and G. L. Paukstis. 1991. Environmental sex determination in reptiles: ecology, evolution, and experimental design. The Quarterly Review of Biology 66(2): 149-179.

Jayne, B. C. and A. F. Bennett. 1990. Selection on locomotor performance capacity in a natural population of garter snakes. Evolution 44: 1204-1229.

Jensen, J. K. 1982. Relations between temperature and incubation time for eggs of the sand lizard (Lacerta agilis L.). Amphibia-Reptilia 2: 385-386.

Kirkpatrick, R. 1999. Bateman Contemporary Atlas of New Zealand - the Shapes of Our Nation. Auckland, David Bateman Ltd. 160 p.

Lang, J. W., H. Andrews and R. Whitaker. 1989. Sex determination and sex ratios in Crocodylus palustris. American Zoologist 29: 935-952.

Lang, J. W. and H. V. Andrews. 1994. Temperature-dependent sex determination in crocodilians. The Journal of Experimental Zoology 270: 28-44.

Lewis-Winokur, V. and R. M. Winokur. 1995. Incubation temperature affects sexual differentiation, incubation time, and posthatching survival in desert tortoises (Gopherus agassizi). Canadian Journal of Zoology 73: 2091-2097.

McCallum, H. 2000. Methods in Ecology, Population Parameters: Estimation for Ecological Models. London, Blackwell Science Ltd. 348 p.

McKenzie, D. W., Ed. 1995. Reed New Zealand Atlas. Auckland, Reed Publishing (NZ) Ltd. Pp 166.

Mittwoch, U. 1996. Sex-determining mechanisms in animals. Trends in Ecology and Evolution 11(2): 63-67.

Morris, K. A., G. C. Packard, T. J. Boardman, G. L. Paukstis and M. J. Packard. 1983. Effect of the hydric environment on growth of embryonic snapping turtles (Chelydra serpentina). Herpetologica 39: 272-285.

Packard, G. C. and M. J. Packard. 1987. Water relations and nitrogen excretion in embryos of the oviparous snake Coluber constrictor. Copeia 1987: 395-406.

Packard, G. C. and J. A. Phillips. 1994. The importance of the physical environment for the incubation of reptilian eggs. Pp 195-208. In J. B. Murphy, K. Adler and J. T. Collins (eds.), Captive Management and Conservation of Amphibians and Reptiles. Society for the Study of Amphibians and Reptiles, Ithaca (New York). Contributions to Herpetology, Volume 11. 
Packard, M. J., G. C. Packard and T. J. Boardman. 1982. Structure of egg shells and water relations of reptilian eggs. Herpetologica 38: 136-155.

Plummer, M. V., C. E. Shadrix and R. C. Cox. 1994. Thermal limits of incubation in embryos of softshell turtles (Apalone mutica). Chelonian Conservation and Biology 1(2): 141-144.

Porter, K. R. 1972. Reproductive adaptations of reptiles, Herpetology. Philadelphia, W. B. Saunders Company. Pp 424-436.

Shine, R. 1983. Reptilian reproductive modes: the oviparity-viviparity continuum. Herpetologica 39(1): 1-8.

Sinervo, B. 1990. The evolution of maternal investment in lizards: an experimental and comparative analysis of egg size and its effects on offspring performance. Evolution 44: 279-294.

Sinervo, B. 1994. Manipulations of clutch and offspring size in lizards: mechanistic, evolutionary, and conservation considerations. Pp 183-193. In J. B. Murphy and J. T. Collins (eds.), Captive Management and Conservation of Amphibians and Reptiles. Society for the Study of Amphibians and Reptiles, New York. Volume 11.

Sinervo, B. and P. Doughty. 1996. Interactive effects of offspring size and timing of reproduction on offspring reproduction: experimental, maternal, and quantitative genetic aspects. Evolution 50(3): 1314-1327.

Smith, C. C. and S. D. Fretwell. 1974. The optimal balance between size and number of offspring. The American Naturalist 108: 499-506.

Sokal, R. R. and F. J. Rohlf. 1981. Biometry: the Principles and Practice of Statistics in Biological Research. Second Edition. U.S.A, W. H. Freeman and Company. 859 p.

Thompson, M. B. 1990. Incubation of eggs of tuatara, Sphenodon punctatus. The Journal of Zoology, London 222: 303-318.

Thoresen, A. C. 1967. Ecological observations on Stanley and Green Islands Mercury Group. Notornis 14(4): 182-200.

Towns, D. R. 1975a. Ecology of the black shore skink, Leiolopisma suteri (Lacertilia: Scincidae), in boulder beach habitats. New Zealand Journal of Zoology 2(4): 389407.

Towns, D. R. 1975b. Reproduction and growth of the black shore skink, Leiolopisma suteri (Lacertilia: Scincidae), in north-eastern New Zealand. New Zealand Journal of Zoology 2(4): 409-423.

Towns, D. R., I. A. E. Atkinson and C. H. Daugherty. 1990. The potential for ecological restoration in the Mercury Islands. Pp 91-108. In D. R. Towns, C. H. Daugherty and I. A. E. Atkinson (eds.), Ecological Restoration of New Zealand Islands. Department of Conservation, Wellington. 
Vinegar, A. 1974. Evolutionary implications of temperature induced anomalies of development in snake embryos. Herpetologica 30: 72-74.

Whitaker, A. H. 1968. Leiolopisma suteri (Boulenger) an oviparous skink in New Zealand. New Zealand Journal of Science 11: 425-432.

Whitaker, A. H. 1973. Lizard populations on islands with and without Polynesian rats, Rattus exulans (Peale). Proceedings of the New Zealand Ecological Society 20(1973): 121-130.

Ynetma, C. L. 1978. Incubation times for the eggs of the turtle Chelydra serpentina (Testudines: Chelydridae) at various temperatures. Herpetologica 34(3): 274-277. 


\section{CHAPTER THREE \\ Incubation regime affects performance of the egg-laying skink, Oligosoma suteri}

\subsection{Introduction}

Biological fitness is the ability of an organism to transfer its genes to the next generation (Hale et al. 1995). Ideally, studies of biological fitness should estimate the contribution of individuals, genotypes and phenotypes to the gene pool for each generation. However, such data are often impossible to obtain. Instead, performance correlates of phenotypic traits, such as size and growth, are frequently used to infer overall fitness of individuals, by their presumed influence on an organism's ability to survive to maturity and thus contribute to the gene pool (Russell 1998). In oviparous reptile species, phenotypic traits such as hatchling size, survival, growth and locomotor fitness can be influenced by incubation conditions (e.g. Brana and Ji 2000, Van Damme et al. 1992).

Large hatchling lizards (Ferguson and Fox 1984, Ferguson and Joanen 1982, Fox 1978), snakes (Jayne and Bennett 1990), and turtles (Alho et al. 1985, Janzen 1993) survive the neonatal period better than small hatchlings in the same cohort. Large hatchlings are assumed to be superior to small hatchlings in competition for food and in locomotor performance, which in turn allow larger animals to grow faster and reach maturity sooner (Froese and Burghadt 1974, Jayne and Bennett 1990, Miller et al. 1987).

Size differences in hatchlings can result from variation in initial egg size, egg quality, incubation temperature, hydric conditions or combinations of these factors (Crump 1984, Packard and Phillips 1994). Usually, hatchlings are larger at optimal incubation temperatures and wetter water potentials. For example, Crocodylus niloticus hatchlings are significantly longer from eggs incubated at $31^{\circ} \mathrm{C}$ than at $28^{\circ} \mathrm{C}$ or $34^{\circ} \mathrm{C}$ (Hutton 1987), and painted turtles (Chrysemys picta) are larger when hatched from eggs 
incubated at wet $(-150 \mathrm{kPa})$ rather than dry $(-1500 \mathrm{kPa})$ water potentials (Packard et al. 1991). Incubation temperature also has long-term effects on post-hatching growth, behaviour and locomotor performance in reptiles (Burger 1989, Joanen et al. 1987). For example, individuals of the skink Bassiana duperreyi incubated in warm conditions $\left(27^{\circ} \mathrm{C} \pm 4^{\circ} \mathrm{C}\right)$ are faster than cool incubated siblings $\left(20^{\circ} \mathrm{C} \pm 4^{\circ} \mathrm{C}\right)$ to 20 weeks of age (Elphick and Shine 1998).

As the only endemic oviparous lizard in New Zealand (Towns 1975a, Thoresen 1967, Whitaker 1968), Oligosoma suteri is the only species whose eggs can be subjected to widely fluctuating incubation conditions. The aim of this chapter is to search for differences in fitness correlates among different incubation groups of $O$. suteri, focusing on the effects of incubation temperature and water potential regimes on hatchling size, growth, survival, and sprint speed. 


\subsection{Methods}

Study area and egg collection methods are described in detail in Chapter 2, sections 2.2.1, 2.2.2 and 2.2.3.

\subsubsection{Incubation of eggs}

A brief summary of egg incubation is presented here. For more detail refer to Chapter 2, section 2.2.4.

One hundred and seventy four $O$. suteri eggs were randomly assigned among three incubation temperatures $\left(18^{\circ} \mathrm{C}, 22^{\circ} \mathrm{C}\right.$ and $\left.26^{\circ} \mathrm{C}\right)$ and two water potentials $(-120 \mathrm{kPa}$ and $-270 \mathrm{kPa}$ ). Eggs were initially placed in separate plastic cups, but when some eggs began to dehydrate, the eggs were reassigned to $2 \mathrm{~L}$ plastic containers. Water potential of the medium grade vermiculite used as an incubation medium was achieved by mixing $100 \mathrm{~g}$ of vermiculite with $96.4 \mathrm{ml}(-120 \mathrm{kPa})$ or $32.6 \mathrm{ml}(-270 \mathrm{kPa})$ of water. Distilled water was added every seven days to compensate for small losses from the container and uptake by the eggs. A $\mathrm{Q}_{10}$ for incubation period was calculated from incubation periods at $22^{\circ} \mathrm{C}$ and $26^{\circ} \mathrm{C}(2.46)$ and used to predict the incubation period for $18^{\circ} \mathrm{C}$ eggs (105 days). When the $18^{\circ} \mathrm{C}$ eggs had not hatched 30 days after the predicted day of hatching, they were randomly assigned to either $18^{\circ} \mathrm{C}$ or $22^{\circ} \mathrm{C}$ for the remainder of incubation.

\subsubsection{Maintenance of juveniles}

Immediately following hatching, juveniles were uniquely toe-clipped to allow for identification (Appendices I and IIa), weighed to $1 \mathrm{mg}$ (on a Sartørius top loading balance), and total-length (TL) and snout-vent length (SVL) measured. Length was measured to $0.5 \mathrm{~mm}$ with a $150 \mathrm{~mm}$ clear plastic ruler. Juveniles were weighed each week, and measured monthly for four months.

Juveniles were housed in identical conditions in groups of three in transparent plastic boxes (New Ocean ${ }^{\mathrm{TM}}$ Plastic No. 838, 215 x 330 x $110 \mathrm{~mm}, 7 \mathrm{~L}$ ), with a square of wire mesh $(165 \times 120 \mathrm{~mm})$ on the lid for airflow. Boxes contained moist, non-fertilised potting mix in the bottom (at least $20 \mathrm{~mm}$ deep), pieces of pine (Pinus radiata) bark for shelter, and water provided ad libitum in a round plastic bowl (30 $\mathrm{mm}$ deep, $70 \mathrm{~mm}$ 
diameter). Individuals incubated at $18^{\circ} \mathrm{C}$ were given shallower $(10 \mathrm{~mm}$ deep, $110 \mathrm{~mm}$ diameter) water dishes due to their inability to exit the deeper ones. To allow for behavioural thermoregulation, skinks had a choice of temperatures, ranging from room temperature $\left(>14.5^{\circ} \mathrm{C}\right)$ to $30^{\circ} \mathrm{C}$ (provided by a strip heater along the back of each box). The boxes were stacked on metal shelves with simulated natural lighting (Duro-test ${ }^{\circledR}$ True-lite ${ }^{\circledR}$ power twist) suspended from the ceiling on a 12L:12D light cycle (lights on at $0600 \mathrm{~h}$ ). Boxes were moved weekly to allow all juveniles access to the light. They were fed three times a week with nymph crickets (Telleogryllus commodus) or vestigial winged fruit flies (Drosophila melanogaster), which were periodically laced with vitamin supplement powder (at least once a week). As juveniles grew, slaters (Porcellio spp.) and houseflies (Musca domestica) were also added to their diet.

\subsubsection{Locomotor performance}

A wooden race track $(70 \mathrm{~mm} \times 1.5 \mathrm{~m})$, with 5 paired infrared lights in slots $(0.25 \mathrm{~m}$ apart and $4 \mathrm{~mm}$ high) over $1 \mathrm{~m}$, was used to test sprint speed. The five infrared lights transmitted and received an infrared beam horizontally across the track. When the first infrared beam was interrupted, four counters, with a pulse rate of $1024 \mathrm{~s}^{-1}$, started on a digital display. The interruption of each successive infrared beam stopped one of the timers (modified from Huey et al. 1981). A horsehair paintbrush was used to encourage running in juveniles by gently touching their tails.

Juvenile sprint speed was tested at one and four months of age with the exception of fifteen $22^{\circ} \mathrm{C}$ and $26^{\circ} \mathrm{C}$ juveniles, which, due to electronic problems with the race track, were sprinted at six weeks. Each age group was sprinted on three consecutive days, with a different ambient temperature $\left(18^{\circ} \mathrm{C}, 22^{\circ} \mathrm{C}\right.$ and $\left.26^{\circ} \mathrm{C} \pm 0.5^{\circ} \mathrm{C}\right)$ each day.

Individuals were sprinted three times each day at one temperature and given at least 15 minutes rest between each test. The order of ambient temperatures was randomised to control for habituation effects. The optimal temperature for $O$. suteri is unknown, and similar experiments on lizards use temperatures in this range (e.g. Elphick and Shine 1998). Juveniles were kept separately in 2 L plastic containers and left undisturbed for at least 30 minutes prior to the sprint test to acclimate to the ambient temperature. The race track was similarly warmed or cooled to the required temperature.

Before the sprint speed test, juveniles were weighed and measured (SVL and TL), each individual also had foot length (FL) and leg length (LL) measured to $0.25 \mathrm{~mm}$. The 
right rear foot was measured on the underside from the heel to the base of the web between the third and fourth digits. The right rear leg was measured along the lateral side from the groin to the ankle. The right and left sides of the animal were viewed from the dorsal surface.

\subsubsection{Data analysis}

Data were analysed using the statistics packages SPSS and S-plus. All data were tested for normality using exploratory analyses on the statistics program SPSS, and statistical significance was assumed at $\mathrm{p}<0.05$. Data are expressed as mean \pm 1 standard error (SE) unless otherwise stated.

The effect of changing from cups to boxes during incubation versus only incubating in boxes was tested by a MANOVA, with a nested water potential and temperature design on SYSTAT. Clutch effects were not investigated as all clutches had five eggs or fewer, too small for powerful statistical tests to be carried out (pers. comm. Edith Hodgen). Thus, the effect of maternal size (SVL) and initial egg mass were used as covariates in analyses as substitutes to allow for any intra-clutch variation. Two very small individuals (outliers) were removed before analysis of hatchling size and growth, which did not alter the results, but did increase the power of the tests.

\subsubsection{Hatchling size}

Only those individuals that hatched without assistance (versus those cut from eggs) were included in hatchling size analyses. Fully developed embryos that failed to hatch unaided suffered from rigor mortis and were too bent to measure accurately, nor was it known whether individuals cut from eggs had reached their maximum size. The effect of incubation regime on hatchling size was assessed using a multivariate general linear model (GLM) on SPSS, with incubation treatments as independent factors, the dependent factors of hatchling size (including SVL, vent-tail length (VTL - obtained by subtracting SVL from TL), TL and Wt), and sex and initial egg mass as covariates.

\subsubsection{Survival}

The effect of incubation regime and initial egg mass on survival to four months of age was assessed using logistic regression models on S-Plus, with the independent factors of incubation treatments (incubation temperature and water potential as categorical data), initial egg mass and sex, and the dependent variable of probability of survival 
$(1=$ survived, $0=$ died $)$. Akaike information criteria were used to determine the bestfit model and which independent factors did not contribute to survival (McCallum 2000). Chi-squared $\left(\chi^{2}\right)$ tests were used to compare models. As $95 \%$ confidence intervals can take the upper limit of probability above one and probability of survival cannot be greater than one ( 1 = survived), $95 \%$ profile likelihood intervals were used.

\subsubsection{Juvenile growth}

Growth to four months of age was assessed using a repeated measures GLM on SPSS, with between-subject factors of incubation temperature and water potential, withinsubject factors of month including size measures (SVL, VTL, TL and mass), and covariates of sex, hatchling size and initial egg mass. Individuals that did not survive to four months of age were excluded from the analysis.

Change in condition from hatching to four months was assessed using ANOVA on SPSS. Condition was measured by an index $\Delta \mathrm{Ci}=\Delta$ mass $/ \Delta \mathrm{TL}$ (modified from Ussher 1999).

\subsubsection{Locomotor performance}

Maximum sprint speed over $0.25 \mathrm{~m}$ was used instead of the full $1 \mathrm{~m}$ as many individuals paused at least once within $1 \mathrm{~m}$. Average sprint speed was not used as an estimate of maximum sprint capacity because only burst speed was correlated with significant survivorship in garter snakes, Thamnophis sirtalis fitchi (Jayne and Bennett 1990). Sprint speed was assessed using a repeated measures GLM on SPSS, with between-subject factors of incubation temperature and water potential, within-subject factors of month and sprint temperature, and covariates of sex, mother size, initial egg mass and most juvenile size measures (including SVL, TL, FL, LL, mass and condition index). Vent-tail length was not used as it was not independent data, that is, it was derived from SVL and TL. Any individuals that did not survive to four months of age were excluded from the analysis. Three outliers were removed before analysis as these individuals either did not sprint $0.25 \mathrm{~m}$ without stopping, or leaped over the infrared beam, giving no reading for that sector. 


\subsection{Results}

There were no significant differences in hatchling size, survival and growth for those individuals incubated only at $18^{\circ} \mathrm{C}$ and those that had incubation temperature raised to $22^{\circ} \mathrm{C}$ near the end of incubation. Therefore, all parameters for these individuals were combined for further analyses. Similarly, there was no significant influence of changing from cups to boxes and no box affect, which allowed for removal of these parameters for the remainder of the analyses. Results from all statistical tests, significant and otherwise, are presented in Appendix IIIb.

\subsubsection{Hatchling size, survival and growth}

Sex of the hatchlings did not influence their size within treatment groups $(F=0.338$, $\mathrm{df}=4, \mathrm{p}=0.852$ ), and was thus removed from further hatchling size analysis. Hatchling size was affected by temperature $(\mathrm{F}=12.248$, df $=6, \mathrm{p}<0.001)$, water potential $(\mathrm{F}=4.597, \mathrm{df}=3, \mathrm{p}=0.005)$ and initial egg mass $(\mathrm{F}=30.218, \mathrm{df}=3$, $\mathrm{p}<0.001$ ), but not any combination of these three factors. Hatchling SVL (Figure 3.1) and mass (Figure 3.2) were largest at $22^{\circ} \mathrm{C}$. Hatchling VTL (Figure 3.3) and TL (Figure 3.4) were longest at the two warmer $\left(22^{\circ} \mathrm{C}\right.$ and $\left.26^{\circ} \mathrm{C}\right)$ temperatures. The effect of water potential on these measures was most pronounced at $26^{\circ} \mathrm{C}$, with very long tails occurring for individuals incubated at $-120 \mathrm{kPa}$. Larger eggs produced larger hatchlings.

Post-hatching juvenile survival was influenced by incubation temperature $\left(\chi^{2}=43.023\right.$, $\mathrm{df}=132,2, \mathrm{p}<0.001$, Table 3.1), but not sex $\left(\chi^{2}=0.475, \mathrm{df}=133,1, \mathrm{p}=0.491\right)$, water potential $\left(\chi^{2}=0.001, \mathrm{df}=133,1, \mathrm{p}=0.970\right)$, initial egg mass $\left(\chi^{2}=0.622, \mathrm{df}=133,1\right.$, $\mathrm{p}=0.431$ ), or any combination of incubation temperature with these 3 factors. The highest probability of surviving to four months occurred at $22^{\circ} \mathrm{C}$ and $26^{\circ} \mathrm{C}$ (Figure 3.5).

Growth to four months was influenced only by incubation temperature $(F=5.137$, $\mathrm{df}=18, \mathrm{p}<0.001$ ); all other variables (water potential, sex, initial egg mass and hatchling size measures) had no effect. Individuals incubated at $22^{\circ} \mathrm{C}$ and $26^{\circ} \mathrm{C}$ grew faster, attaining a larger size in all size measures than $18^{\circ} \mathrm{C}$ individuals. 


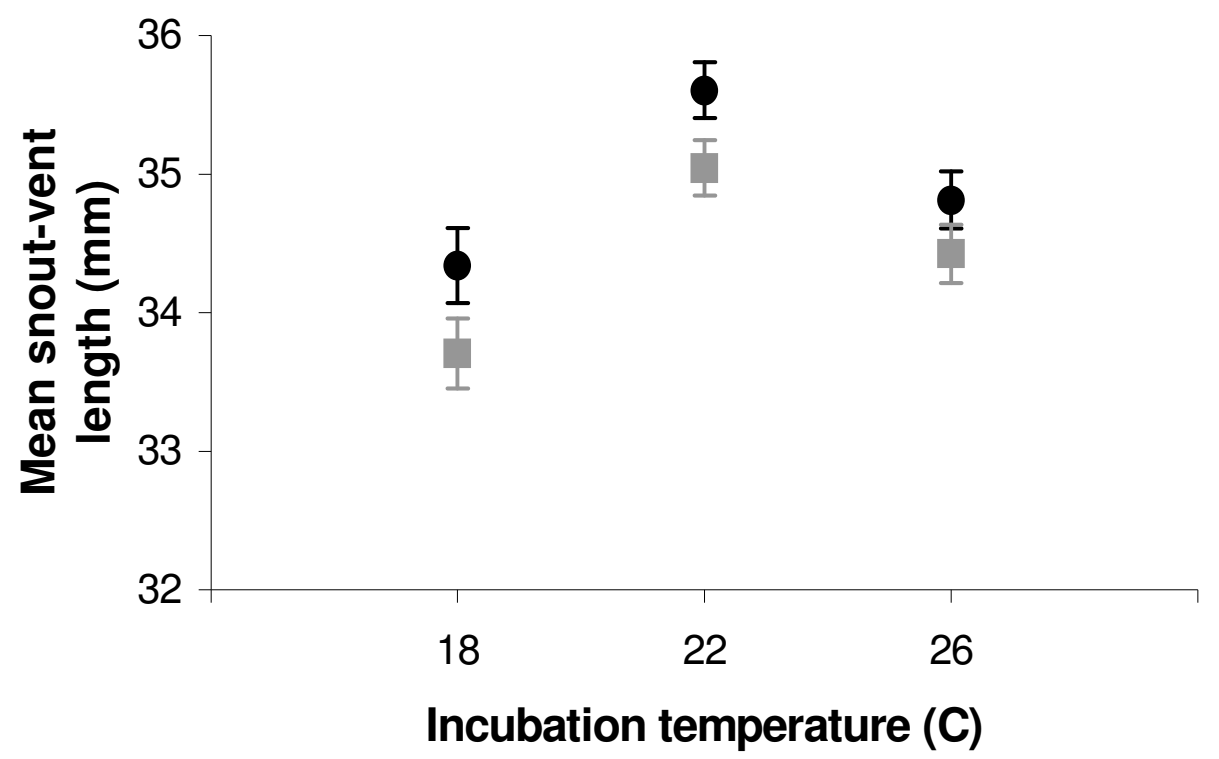

Figure 3.1 Mean snout-vent length $(\mathrm{mm}) \pm \mathrm{SE}$ of hatchlings for each incubation temperature $\left({ }^{\circ} \mathrm{C}\right)$ and water potential $(\bullet=-120 \mathrm{kPa}, \square=-270 \mathrm{kPa})$. Note that $18^{\circ} \mathrm{C}$ includes individuals that completed the last part of incubation at either $18^{\circ} \mathrm{C}$ or $22^{\circ} \mathrm{C}$.

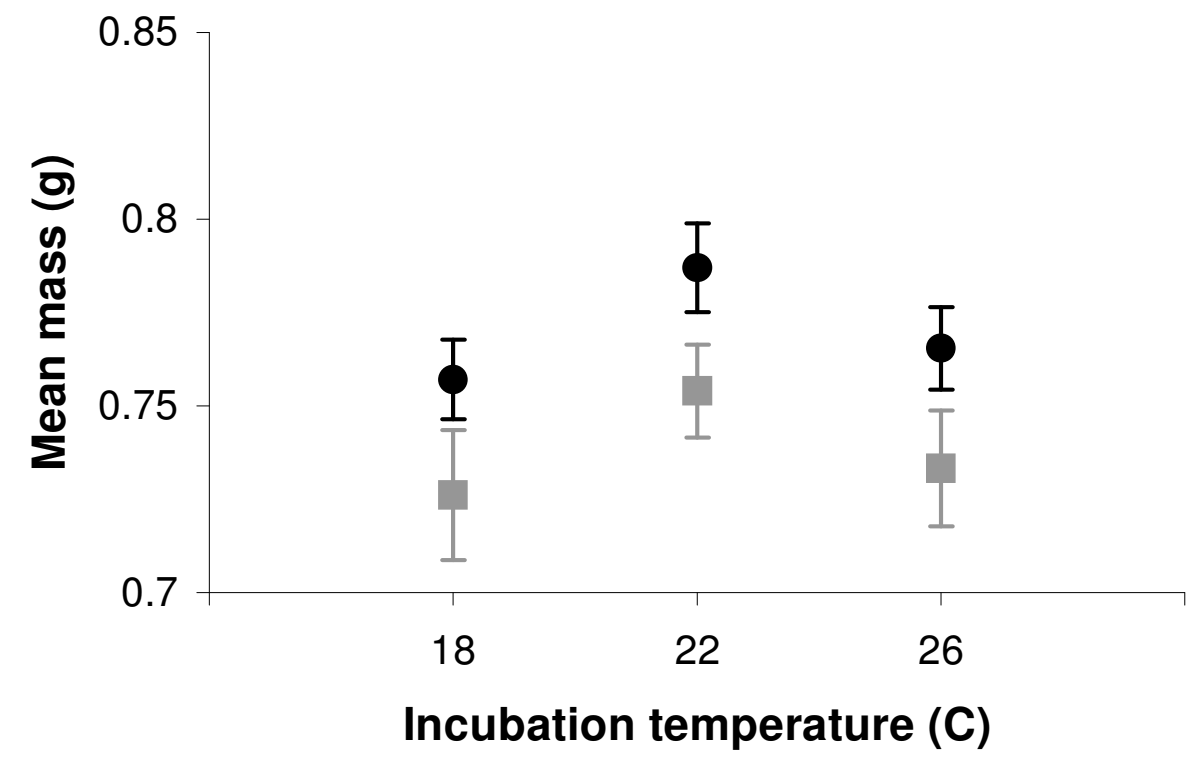

Figure 3.2 Mean mass $(\mathrm{g}) \pm \mathrm{SE}$ of hatchlings for each incubation temperature $\left({ }^{\circ} \mathrm{C}\right)$ and water potential $(\bullet=-120 \mathrm{kPa}, \varpi=-270 \mathrm{kPa})$. Note that $18^{\circ} \mathrm{C}$ includes individuals that completed the last part of incubation at either $18^{\circ} \mathrm{C}$ or $22^{\circ} \mathrm{C}$. 


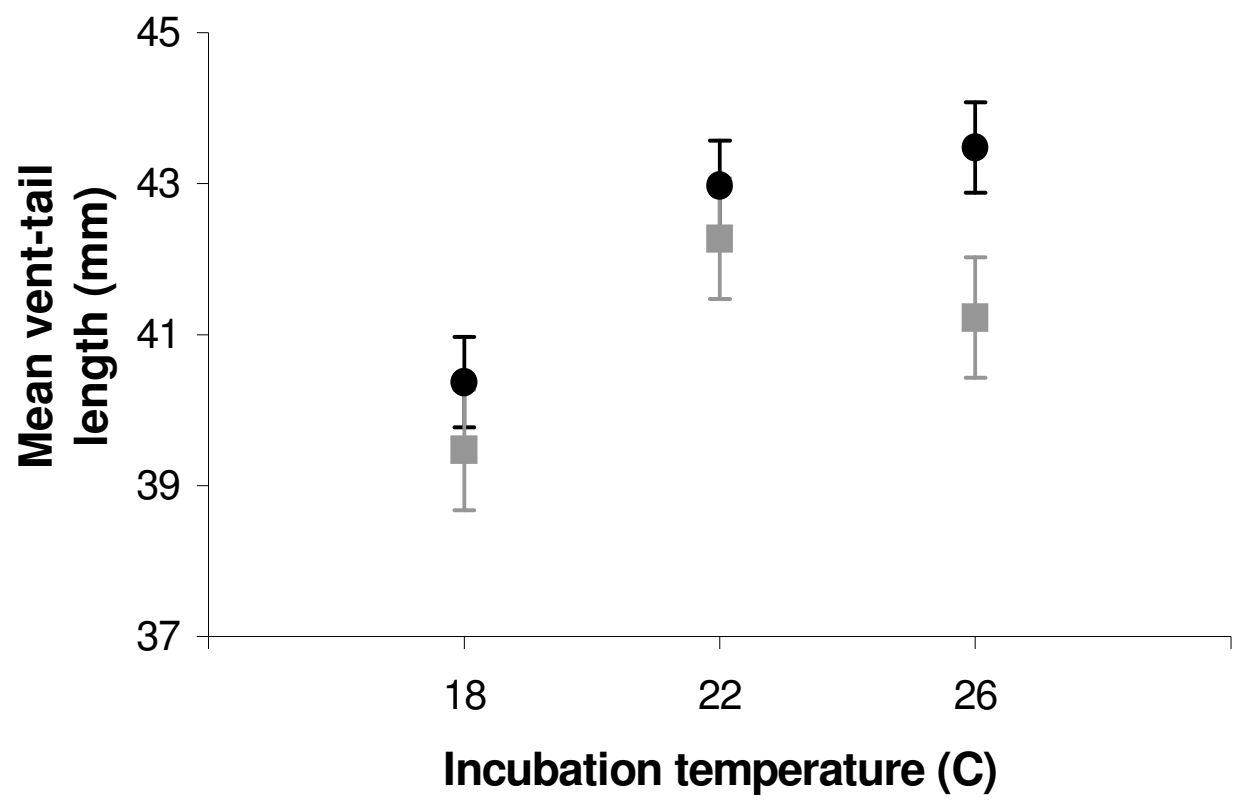

Figure 3.3 Mean vent-tail length $(\mathrm{mm}) \pm \mathrm{SE}$ of hatchlings for each incubation temperature $\left({ }^{\circ} \mathrm{C}\right)$ and water potential $(\bullet=-120 \mathrm{kPa},=-270 \mathrm{kPa})$. Note that $18^{\circ} \mathrm{C}$ includes individuals that completed the last part of incubation at either $18^{\circ} \mathrm{C}$ or $22^{\circ} \mathrm{C}$.

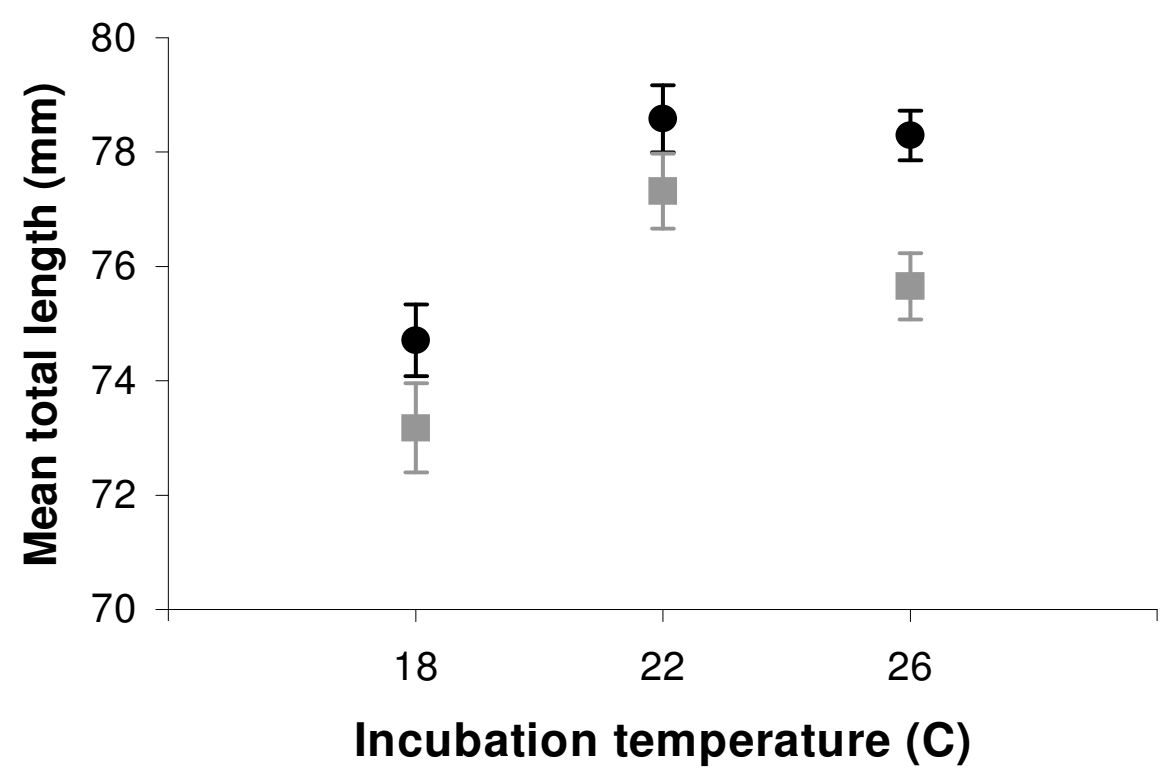

Figure 3.4 Mean total length $(\mathrm{mm}) \pm \mathrm{SE}$ of hatchlings for each incubation temperature $\left({ }^{\circ} \mathrm{C}\right)$ and water potential $(\bullet=-120 \mathrm{kPa}, \backsim=-270 \mathrm{kPa})$. Note that $18^{\circ} \mathrm{C}$ includes individuals that completed the last part of incubation at either $18^{\circ} \mathrm{C}$ or $22^{\circ} \mathrm{C}$. 
Table 3.1 Hatchling survival amongst incubation temperatures ( $\mathrm{T}=$ temperature).

\begin{tabular}{|c|c|c|c|c|c|c|}
\hline \multirow{2}{*}{$\begin{array}{c}\mathbf{T} \\
\left({ }^{\circ} \mathbf{C}\right)\end{array}$} & \multirow{2}{*}{$\begin{array}{c}\text { No. } \\
\text { Hatchlings }\end{array}$} & \multicolumn{4}{|c|}{ No. Died } & \multirow{2}{*}{$\begin{array}{c}\text { No. alive at } \\
4 \text { months } \\
(\%)\end{array}$} \\
\hline & & Month 1 & Month 2 & Month 3 & Month 4 & \\
\hline 18 & 37 & 12 & 1 & 3 & 0 & $21(57 \%)$ \\
\hline 22 & 50 & 0 & 0 & 0 & 0 & $50(100 \%)$ \\
\hline 26 & 49 & 1 & 0 & 0 & 0 & $48(98 \%)$ \\
\hline
\end{tabular}

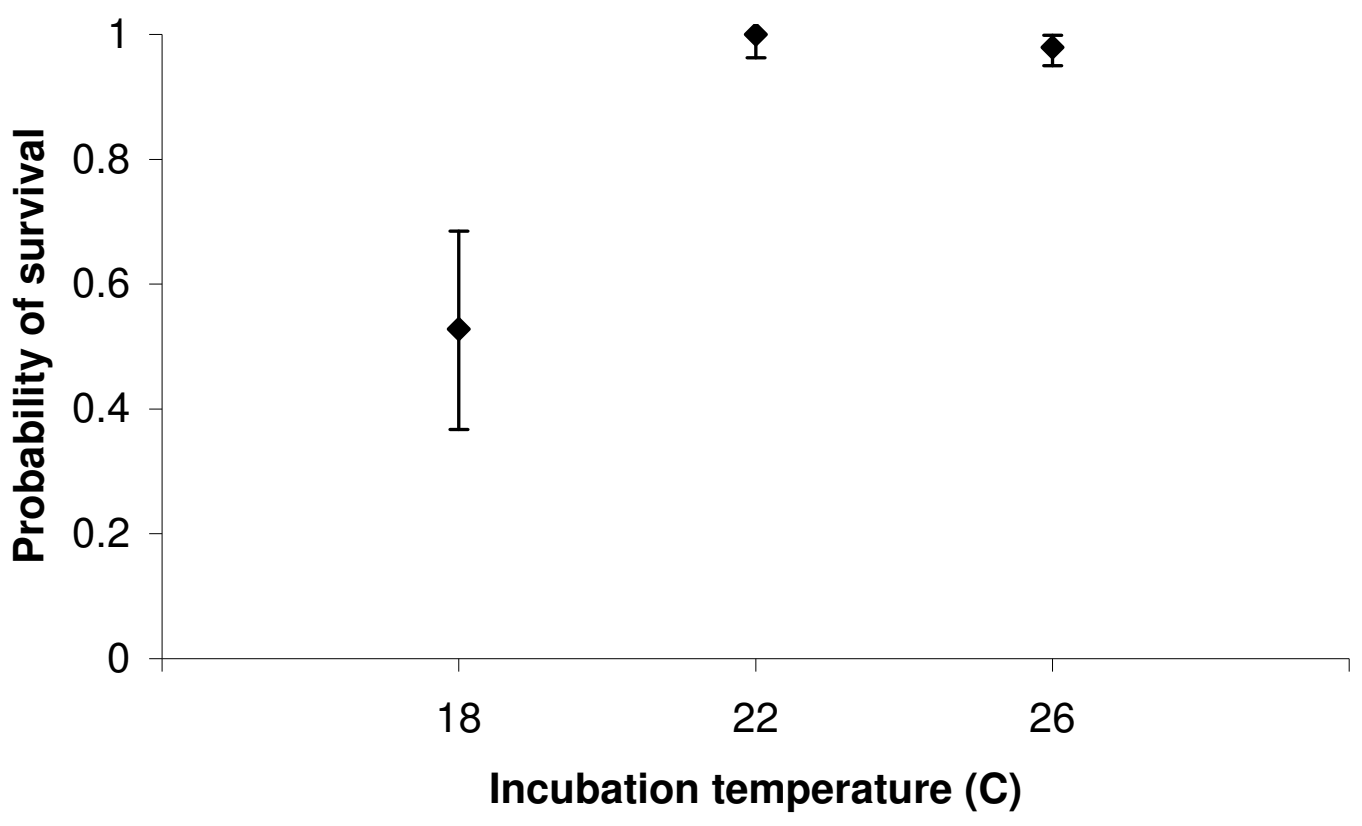

Figure 3.5 Probability of surviving at each incubation temperature $\pm 95 \%$ profile likelihood intervals. Note that $18^{\circ} \mathrm{C}$ includes individuals that completed the last part of incubation at either $18^{\circ} \mathrm{C}$ or $22^{\circ} \mathrm{C}$.

Change in condition index from hatching to four months was influenced by incubation temperature $(\mathrm{F}=51.913, \mathrm{df}=2, \mathrm{p}<0.001)$, but not water potential $(\mathrm{F}=1.501, \mathrm{df}=1, \mathrm{p}$ $=0.223)$, initial egg mass $(\mathrm{F}=0.777, \mathrm{df}=1, \mathrm{p}=0.380)$, or a combination of the two incubation treatments. Condition index was not significantly different between the three incubation temperatures at hatching, but by four months the individuals incubated at $22^{\circ} \mathrm{C}$ and $26^{\circ} \mathrm{C}$ had a greater condition index than the $18^{\circ} \mathrm{C}$ individuals (Figure 3.6), that is, they weighed more per unit length. However, at four months individuals incubated at $26^{\circ} \mathrm{C}$ and $-270 \mathrm{kPa}$ weighed less per unit length than those incubated at $26^{\circ} \mathrm{C}$ and $-120 \mathrm{kPa}$. 


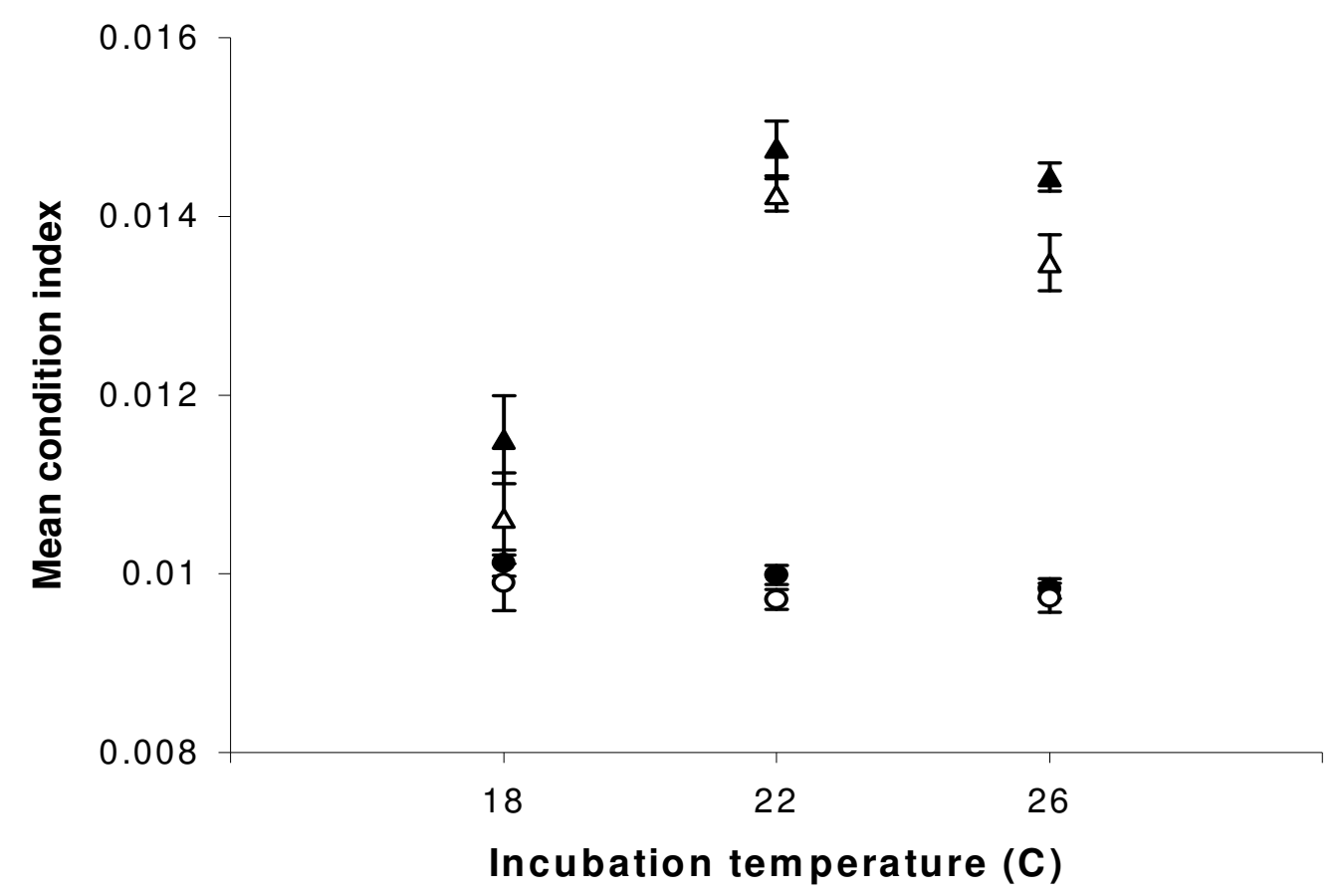

Figure 3.6 Mean condition index \pm SE for each incubation temperature and water potential at hatching and four months $(\bullet=0$ months at $-120 \mathrm{kPa}, \circ=0$ months at $-270 \mathrm{kPa}$, $\boldsymbol{\Delta}=4$ months at $-120 \mathrm{kPa}, \Delta=$ four months at $-270 \mathrm{kPa}$ ). Note that $18^{\circ} \mathrm{C}$ includes individuals that completed the last part of incubation at either $18^{\circ} \mathrm{C}$ or $22^{\circ} \mathrm{C}$.

\subsubsection{Locomotor performance}

Sprint speed was influenced by incubation temperature $(\mathrm{F}=9.348$, df $=2, \mathrm{p}<0.001)$ and condition index $(\mathrm{F}=9.348, \mathrm{df}=1, \mathrm{p}=0.003)$, but not by water potential, sex, initial egg mass, size measurements (snout-vent length, total length, mass, leg length or foot length), or maternal SVL, although initial egg mass had an effect when both month and sprint temperature were combined $(\mathrm{F}=6.968, \mathrm{df}=2, \mathrm{p}=0.002)$. All individuals had faster sprint speeds at warmer ambient temperatures. For all ambient temperatures at one month, individuals from the warmer incubation temperatures $\left(22^{\circ} \mathrm{C}\right.$ and $\left.26^{\circ} \mathrm{C}\right)$ were faster, with no significant difference between the two (Figure 3.7). The same trend was apparent for four month sprint speeds, with no difference between sprint speed at one and four months for $22^{\circ} \mathrm{C}$ and $26^{\circ} \mathrm{C}$ incubated individuals, with the exception of $26^{\circ} \mathrm{C}(-270 \mathrm{kPa})$ individuals which were slower at four months at the ambient temperature of $26^{\circ} \mathrm{C}$. The $18^{\circ} \mathrm{C}$ individuals were significantly slower over all ambient temperatures at four months (Figure 3.7). 


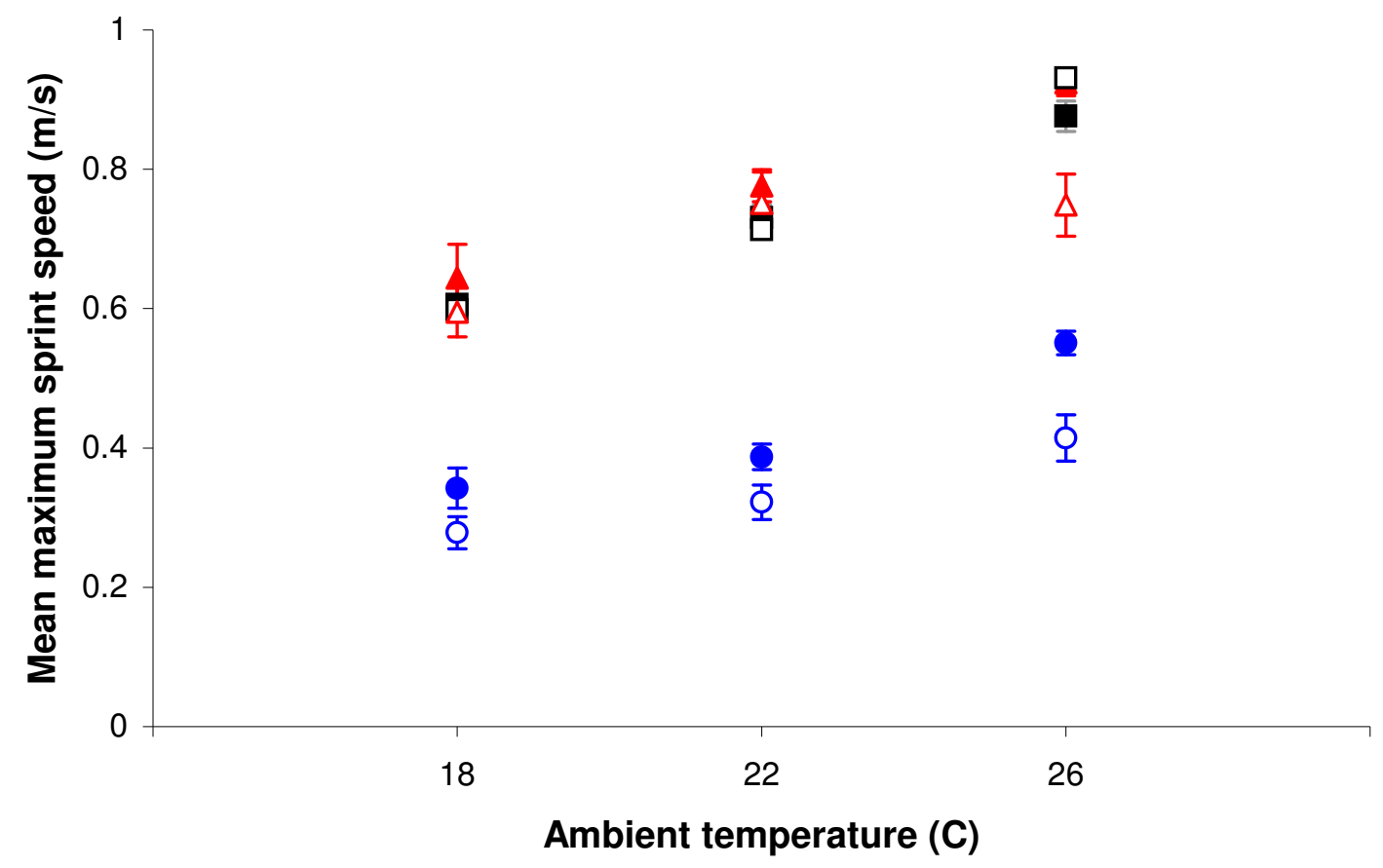

Figure 3.7 Mean maximum sprint speeds $\left(\mathrm{ms}^{-1} \pm \mathrm{SE}\right)$ at each ambient temperature for individuals from each incubation temperature at one and four months $(\bullet=1$ month and $18^{\circ} \mathrm{C}$ incubation temperature, $\circ=4$ months and $18^{\circ} \mathrm{C}$ incubation temperature, - = 1 month and $22^{\circ} \mathrm{C}$ incubation temperature, $\square=4$ months and $22^{\circ} \mathrm{C}$ incubation temperature, $\Delta=1$ month and $26^{\circ} \mathrm{C}$ incubation temperature, $\Delta=4$ months and $26^{\circ} \mathrm{C}$ incubation temperature). Note that $18^{\circ} \mathrm{C}$ includes individuals that completed the last part of incubation at either $18^{\circ} \mathrm{C}$ or $22^{\circ} \mathrm{C}$. 


\subsection{Discussion}

\subsubsection{Hatchling size, survival and growth}

Large hatchlings are thought to be superior to small hatchlings due to improved competitive ability, as well as greater locomotor performance and thus success at evading predators (Froese and Burghadt 1974, Morris et al. 1983, Sinervo and Huey 1990). An increase in hatchling size at an optimal (increased survival) temperature is a common phenomenon in oviparous reptiles (e.g. Choo and Chou 1987, Jensen 1982, Lang et al. 1989, Marcovaldi et al. 1997, Van Damme et al. 1992, Ynetma 1978). For most measurements, hatchlings of $O$. suteri were larger at a constant incubation temperature of $22^{\circ} \mathrm{C}$, although tail length of $26^{\circ} \mathrm{C}$ individuals was significantly longer at $-120 \mathrm{kPa}$. A similar pattern occurs in some other squamates where hatchlings are larger from moderate incubation temperatures than from low or high incubation temperatures. For example, hatchlings of the agamid lizard Ctenophorus ornatus (Harlow 2000) and the bull snake Pituophis melanoleucus (Gutzke and Packard 1987) are larger from intermediate incubation temperatures. The bull snake also suffers from physiological abnormalities and low hatching success at high incubation temperatures close to the upper lethal limit (Gutzke and Packard 1987).

Influence of water potential on hatchling size has mostly been studied in turtles, where larger hatchlings are produced at wetter water potentials, such as in the snapping turtle, Chelydra serpentina (Morris et al. 1983). This pattern is also common in squamates, as eggs of oviparous squamate reptiles usually have thin, flexible shells with little resistance to water movement from the surrounding environment (Packard et al. 1982). In $O$. suteri hatchling size was positively correlated with water potential.

Hatchling survival probability was significantly greater at the two warmer $\left(22^{\circ} \mathrm{C}\right.$ and $26^{\circ} \mathrm{C}$ ) incubation temperatures. Incubation temperature also influences survival probability of other oviparous reptile neonates, such as in desert tortoises (Gopherus agassiz), where highest survival to 277 days occurs at optimal temperatures $\left(28^{\circ} \mathrm{C}\right.$, $29^{\circ} \mathrm{C}$ and $31^{\circ} \mathrm{C}$ ) compared with sub-optimal temperatures of $25^{\circ} \mathrm{C}$ and $27^{\circ} \mathrm{C}$ (LewisWinokur and Winokur 1995). 
Many studies of reptiles show a relationship between survival and body size. For example, in wild populations of the lizard Uta stansburiana, a greater proportion of large than small individuals survive to breeding age (Ferguson and Fox 1984). However, there are exceptions, such as in a population of snapping turtles (Chelydra serpentina), where a seven year study failed to show any correlation between large size and higher survival (Congdon et al. 1999). For relict mainland populations of $O$. suteri, which experience mammalian predators and human interference, faster growth rates and larger size are likely to be of an advantage to individuals, allowing quicker attainment of maturity and potentially earlier reproduction.

In $O$. suteri, growth to four months was faster in neonates from the two warmer incubation temperatures than those from $18^{\circ} \mathrm{C}$. Effects of incubation regime on growth are also common in other reptiles, such as hatchling Cuban rock iguanas (Cyclura nubila), which grow faster in their first year when incubated at high $\left(31^{\circ} \mathrm{C}\right)$ incubation temperatures (Alberts et al. 1997).

The condition indices of $O$. suteri hatchlings from all incubation regimes were similar, probably due to individuals receiving approximately the same amount of nutrients from eggs. Eggs were all of similar mass regardless of maternal size (Chapter 2, section 2.3.1). At four months, $22^{\circ} \mathrm{C}$ and $26^{\circ} \mathrm{C}$ incubated individuals had a significantly higher condition index, which is consistent with casual observations that $18^{\circ} \mathrm{C}$ individuals had reduced ability to catch food.

There was no difference in hatchling size and growth between the sexes, which was expected as there is no external secondary sexual dimorphism in O. suteri. Ventral colouration differs between sexes during the breeding season, although this is not a definitive sex determining character (Towns 1975b). The genus Oligosoma typically shows little sexual dimorphism, with individuals often difficult to sex without dissection (Barwick 1959). 


\subsubsection{Locomotor performance}

Greater locomotor performance, such as faster sprint speed, may allow individuals to evade predators more successfully and increase ability to catch food, which can in turn increase growth rate, and thus size at maturity and potentially reproductive success (Downes and Shine 1999, Froese and Burghadt 1974, Jayne and Bennett 1990). Faster speed has been correlated with both incubation regime and individual size in many reptiles (e.g. Elphick and Shine 1998, Macrini and Irschick 1998, Miller et al. 1987, Sinervo 1990). Size does not influence sprint speed in juvenile $O$. suteri, but incubation temperature does, with those individuals incubated at $22^{\circ} \mathrm{C}$ and $26^{\circ} \mathrm{C}$ sprinting faster than $18^{\circ} \mathrm{C}$ individuals. Sprint speed is also positively correlated with condition index. No individuals sprinted faster at four months than one month; moreover, a slower burst speed (at four months compared with one month) was obtained for individuals incubated at $18^{\circ} \mathrm{C}$ and $26^{\circ} \mathrm{C}(-270 \mathrm{kPa})$. This is the first study to report a decrease in sprint speed as individuals get older. It is worth noting that the smaller hatchling size of $26^{\circ} \mathrm{C}$ incubated individuals and slower sprint speed at warmer ambient temperatures indicate that $26^{\circ} \mathrm{C}$ may be close to, but not at, the upper lethal limit.

\subsubsection{Implications}

Like all reptiles, $O$. suteri physiology is influenced by incubation temperature. Current global warming predictions estimate an increase in mean global temperature of between $1.4^{\circ} \mathrm{C}$ and $5.8^{\circ} \mathrm{C}$ and an increase in sea level of between $9 \mathrm{~mm}$ and $88 \mathrm{~mm}$ by 2100 (IPCC 2001). Habitat preference and restricted distribution of $O$. suteri make this species particularly vulnerable to global climate change and sea level rises. However, sea level rise may prove to be detrimental only if island sanctuaries are completely submerged, whereas data on natural nest temperatures are needed before effects of increased global temperatures can be ascertained.

Potentially, the mainland populations of $O$. suteri could extend their range southward if global temperatures increase, but suitable boulder beach habitats are not found in a continuum. Also, due to mammalian predators and human interference, most populations of this skink occur on offshore islands (Towns and Daugherty 1994), which, when coupled with sea level rise, indicates that they will have limited opportunity to disperse towards suitable, cooler habitats. 


\subsubsection{Conclusion}

The data presented in this chapter are consistent with previous studies that have demonstrated differences in phenotypic traits of hatchling reptiles in response to incubation conditions (e.g. Brana and Ji 2000, Miller et al. 1987, Shine et al. 1997, Steyermark and Spotila 2001). However, the data are based entirely on the first four months of life, and $O$. suteri are long lived (at least 12 years on offshore islands, Towns and Ferreira 2001). Their phenotypic responses to incubation conditions may alter with age, although this is very unlikely in the $18^{\circ} \mathrm{C}$ incubated individuals. Nonetheless, other studies have suggested that incubation induced phenotypic changes may persist for long periods of time (Andrews et al. 2000, Elphick and Shine 1998, Joanen et al. 1987, Shine et al. 1995), although this is by no means direct evidence of a link with biological fitness. The population of captively incubated and reared skinks used in this study will be released onto Korapuki Island, as part of the restoration goals for the island. This provides an excellent opportunity to assess the long-term effects of constant, captive incubation regime on phenotypic traits and ultimately biological fitness of $O$. suteri. 


\subsection{References}

Alberts, A. C., A. M. Perry, J. M. Lemm and J. A. Phillips. 1997. Effects of incubation temperature and water potential on growth and thermoregulatory behaviour of hatchling Cuban rock iguanas (Cyclura nubila). Copeia 1997(4): 766-776.

Alho, C. J. R., T. M. S. Danni and L. F. M. Padua. 1985. Temperature-dependent sex determination in Podocnemis expansa (Testudinata: Pelomedusidae). Biotropica 17: $75-78$.

Andrews, R. M., T. Mathies and D. A. Warner. 2000. Effect of incubation temperature on morphology, growth, and survival of juvenile Sceloporus undulatus. Herpetological Monographs 14: 420-431.

Barwick, R. E. 1959. The life history of the common New Zealand skink Leiolopisma zelandica (Gray. 1843). Transactions of the Royal Society of New Zealand 86: 331380.

Brana, F. and X. Ji. 2000. Influence of incubation temperature on morphology, locomotor performance, and early growth of hatchling wall lizards (Podarcis mularis). Journal of Experimental Zoology 286: 422-433.

Burger, J. 1989. Incubation temperature has long-term effects on behaviour of young pine snakes (Pituophis melanoleucus). Behavioural Ecology and Sociobiology 24: 201-207.

Choo, B. L. and L. M. Chou. 1987. Effect of temperature on the incubation period and hatchability of Trionyx sinensis Weigmann eggs. Journal of Herpetology 21(3): 230-232.

Congdon, J. D., R. D. Nagle, A. E. Dunham, C. W. Beck, O. M. Kinney and S. R. Yeomans. 1999. The relationship of body size to survivorship of hatchling snapping turtles (Chelydra serpentina): an evaluation of the "bigger is better" hypothesis. Oecologia 121: 224-235.

Crump, M. L. 1984. Intraclutch egg size variability in Hyla crucifer (Anura: Hylidae). Copeia 1984(2): 302-308.

Downes, S. J. and R. Shine. 1999. Do incubation-induced changes in a lizard's phenotype influence its vulnerability to predators? Oecologia 120(1): 9-18.

Elphick, M. J. and R. Shine. 1998. Longterm effects of incubation temperatures on the morphology and locomotor performance of hatchling lizards (Bassiana duperreyi, Scincidae). Biological Journal of the Linnean Society 63: 429-447.

Ferguson, G. W. and S. F. Fox. 1984. Annual variation of survival advantage of large juvenile side-blotched lizards, Uta stansburiana: its causes and evolutionary significance. Evolution 38: 342-349.

Ferguson, M. W. J. and T. Joanen. 1982. Temperature of egg incubation determines sex in Alligator mississippiensis. Nature 296: 850-853. 
Fox, S. F. 1978. Natural selection on the behavioural phenotypes of the lizard Uta stansburiana. Ecology 59: 834-847.

Froese, A. D. and G. M. Burghadt. 1974. Food competition in captive juvenile snapping turtles, Chelydra serpentina. Animal Behaviour 22: 735-740.

Gutzke, W. H. N. and G. C. Packard. 1987. Influence of the hydric and thermal environments on eggs and hatchlings of bull snakes Pituophis melanoleucus. Physiological Zoology 60(1): 9-17.

Hale, W. G., J. P. Margham and V. A. Saunders. 1995. Collins Dictionary of Biology, Second Edition. Glasgow, Harper Collins Publishers. 656 p.

Harlow, P. S. 2000. Incubation temperature determines hatchling sex in Australian rock dragons (Agamidae: Genus Ctenophorus). Copeia 2000(4): 958-964.

Huey, R. B., W. Schneider, G. L. Erie and R. D. Stevenson. 1981. A field-portable racetrack and timer for measuring acceleration and speed of small cursorial animals. Experientia 37(1981): 1356-1357.

Hutton, J. M. 1987. Incubation temperatures, sex ratios and sex determination in a population of Nile crocodiles (Crocodylus niloticus). The Journal of Zoology, London 211: 143-155.

IPCC. 2001. Climate Change 2001: the Scientific Basis, Intergovernmental Panel on Climate Change, Cambridge University Press. (in press).

Janzen, F. J. 1993. An experimental analysis of natural selection on body size of hatchling turtles. Ecology 74(2): 332-341.

Jayne, B. C. and A. F. Bennett. 1990. Selection on locomotor performance capacity in a natural population of garter snakes. Evolution 44: 1204-1229.

Jensen, J. K. 1982. Relations between temperature and incubation time for eggs of the sand lizard (Lacerta agilis L.). Amphibia-Reptilia 2: 385-386.

Joanen, T., L. McNease and M. W. J. Ferguson. 1987. The effects of egg incubation temperature on post-hatching growth of American alligators. Pp 533-537. In G. J. W. Webb, S. C. Manolis and P. J. Whitehead (eds.), Wildlife Management: Crocodiles and Alligators. Surry Beatty and Sons Pty Limited, Louisiana.

Lang, J. W., H. Andrews and R. Whitaker. 1989. Sex determination and sex ratios in Crocodylus palustris. American Zoologist 29: 935-952.

Lewis-Winokur, V. and R. M. Winokur. 1995. Incubation temperature affects sexual differentiation, incubation time, and posthatching survival in desert tortoises (Gopherus agassizi). Canadian Journal of Zoology 73: 2091-2097.

Macrini, T. E. and D. J. Irschick. 1998. An intraspecific analysis of trade-offs in sprinting performance in a West Indian lizard species (Anolis lineatopus). Biological Journal of the Linnean Society 63: 579-591. 
Marcovaldi, M. A., M. H. Godfrey and N. Mrosovsky. 1997. Estimating sex ratios of loggerhead turtles in Brazil from pivotal incubation durations. Canadian Journal of Zoology 75: 755-770.

McCallum, H. 2000. Population Parameters: Estimation for Ecological Models, London, Blackwell Science Ltd. 348 p.

Miller, K., G. C. Packard and M. J. Packard. 1987. Hydric conditions during incubation influence locomotor performance of hatchling snapping turtles. Journal of Experimental Biology 127: 401-412.

Morris, K. A., G. C. Packard, T. J. Boardman, G. L. Paukstis and M. J. Packard. 1983. Effect of the hydric environment on growth of embryonic snapping turtles (Chelydra serpentina). Herpetologica 39: 272-285.

Packard, G. C., M. J. Packard and L. Benigan. 1991. Sexual differentiation, growth, and hatching success by embryonic painted turtles incubated in wet and dry environments at fluctuating temperatures. Herpetologica 47(1): 125-132.

Packard, G. C. and J. A. Phillips. 1994. The importance of the physical environment for the incubation of reptilian eggs. Pp 195-208. In J. B. Murphy, K. Adler and J. T. Collins (eds.), Captive Management and Conservation of Amphibians and Reptiles. Society for the Study of Amphibians and Reptiles, Ithaca (New York). Contributions to Herpetology, Volume 11.

Packard, M. J., G. C. Packard and T. J. Boardman. 1982. Structure of egg shells and water relations of reptilian eggs. Herpetologica 38: 136-155.

Russell, P. J. 1998. Genetics, Fifth Edition. Menlo Park, California, Benjamin/Cummings. 805 p.

Shine, R., M. J. Elphick and P. S. Harlow. 1995. Sisters like it hot. Nature 378: 451452.

Shine, R., M. J. Elphick and P. S. Harlow. 1997. The influence of natural incubation environments on the phenotypic traits of hatchling lizards. Ecology 78(8): 25592568.

Sinervo, B. 1990. The evolution of maternal investment in lizards: an experimental and comparative analysis of egg size and its effects on offspring performance. Evolution 44: 279-294.

Sinervo, B. and R. B. Huey. 1990. Allometric engineering: an experimental test of the causes of interpopulational differences in performance. Science 248: 1106-1109.

Steyermark, A. C. and J. R. Spotila. 2001. Effects of maternal identity and incubation temperature on hatching and hatchling morphology in snapping turtles, Chelydra serpentina. Copeia 2001(1): 129-135.

Thoresen, A. C. 1967. Ecological observations on Stanley and Green Islands Mercury Group. Notornis 14(4): 182-200. 
Towns, D. R. 1975a. Ecology of the black shore skink, Leiolopisma suteri (Lacertilia: Scincidae), in boulder beach habitats. New Zealand Journal of Zoology 2(4): 389407.

Towns, D. R. 1975b. Reproduction and growth of the black shore skink, Leiolopisma suteri (Lacertilia: Scincidae), in north-eastern New Zealand. New Zealand Journal of Zoology 2(4): 409-423.

Towns, D. R. and C. H. Daugherty. 1994. Patterns of range contractions and extinctions in the New Zealand herpetofauna following human colonisation. New Zealand Journal of Zoology 21: 325-339.

Towns, D. R. and S. M. Ferreira. 2001. Conservation of New Zealand lizards (Lacertilia: Scincidae) by translocation of small populations. Biological Conservation 98(2): 211-222.

Ussher, G. 1999. Restoration of Threatened Species Populations: Tuatara Rehabilitations and Re-introductions. Unpublished Ph.D Thesis. School of Environmental and Marine Sciences. University of Auckland. 222 p.

Van Damme, R., D. Bauwens and F. Brana. 1992. Incubation temperature differentially affects hatching time, egg survival, and hatchling performance in the lizard Podarcis muralis. Herpetologica 48(2): 220-228.

Whitaker, A. H. 1968. Leiolopisma suteri (Boulenger) an oviparous skink in New Zealand. New Zealand Journal of Science 11: 425-432.

Ynetma, C. L. 1978. Incubation times for the eggs of the turtle Chelydra serpentina (Testudines: Chelydridae) at various temperatures. Herpetologica 34(3): 274-277. 


\section{CHAPTER FOUR}

\section{Summary and recommendations}

This thesis contributes to the understanding of the reproductive biology of Oligosoma suteri by demonstrating the effects of incubation regime on various ecological factors, in particular, how incubation temperatures and water potentials affect incubation period, hatchling morphology, sex, embryonic and juvenile survival, hatchling growth and juvenile locomotor performance.

Oligosoma suteri eggs $(\mathrm{n}=174)$ were randomly distributed among three different constant incubation temperatures and two water potentials. Incubation period, embryonic development, hatchling size, growth, survival and sprint speed were affected by incubation regime, with the greatest influence accredited to temperature. Sex of individuals was not influenced by incubation regime, and therefore $O$. suteri do not have temperature-dependent sex determination. The lower lethal limit is close to or at $18^{\circ} \mathrm{C}$, and constant $26^{\circ} \mathrm{C}$ incubation may be close to the upper lethal limit.

\subsection{Summary of results}

- At oviposition embryos are at stage 32 according to the staging series for Lacerta vivipara, which is two stages later than for most other oviparous reptiles.

- Maternal size (SVL) and clutch size are positively correlated as in other reptile species.

- Incubation period is longer at cooler temperatures, with no influence attributed to an increase in temperature in the final 10 to 29 days of incubation.

- Change in egg mass during incubation is positively correlated with incubation temperature, water potential and initial egg mass.

- Hatching success is greatest at warmer incubation temperatures $\left(22^{\circ} \mathrm{C}\right.$ and $\left.26^{\circ} \mathrm{C}\right)$.

- Hatchlings from constant $18^{\circ} \mathrm{C}$ incubation suffer from physical abnormalities, similar to other squamate reptiles incubated at or near the lower lethal limit. 
- Sex ratio is close to 50:50 for all incubation treatments, so sex is probably genetically determined.

- Hatchling size is larger, in most measurements, at constant $22^{\circ} \mathrm{C}$ incubation and $-120 \mathrm{kPa}$. Growth is greatest in hatchlings incubated at the two warmer incubation temperatures.

- Condition index (mass per unit length) is similar for all hatchlings, but only $22^{\circ} \mathrm{C}$ and $26^{\circ} \mathrm{C}$ individuals increased their condition after four months.

- Survival to four months is higher in individuals hatched from the two warmer incubation temperatures; only $57 \%$ of hatched individuals survive from $18^{\circ} \mathrm{C}$ incubation.

- Sprint speed is positively correlated with incubation temperature and condition index but not influenced by size or age of individuals. Furthermore, individuals incubated at $18^{\circ} \mathrm{C}$ or $26^{\circ} \mathrm{C}(-270 \mathrm{kPa})$ had slower sprint speeds at four months than at one month.

\subsection{Recommendations}

Future captive rearing of $O$. suteri should use constant $22{ }^{\circ} \mathrm{C}$ and $-120 \mathrm{kPa}$, ensuring larger hatchlings with higher survival probability and greater fitness measures to at least four months of age. Translocation of $O$. suteri populations should only be done within their current geographic range.

\subsection{Future research}

Based on the findings from this thesis, I suggest four future avenues of research: a) determine natural nest temperatures of $O$. suteri and analyse how increases in global temperatures will influence $O$. suteri, b) study the long-term effects of constant, captive incubation regimes on this species by monitoring the population after release, c) test fitness measures of natural populations and compare with the captive incubated individuals, and d) determine whether $O$. suteri has heteromorphic sex chromosomes. 


\section{APPENDIX I}

\section{Toe-clip information}

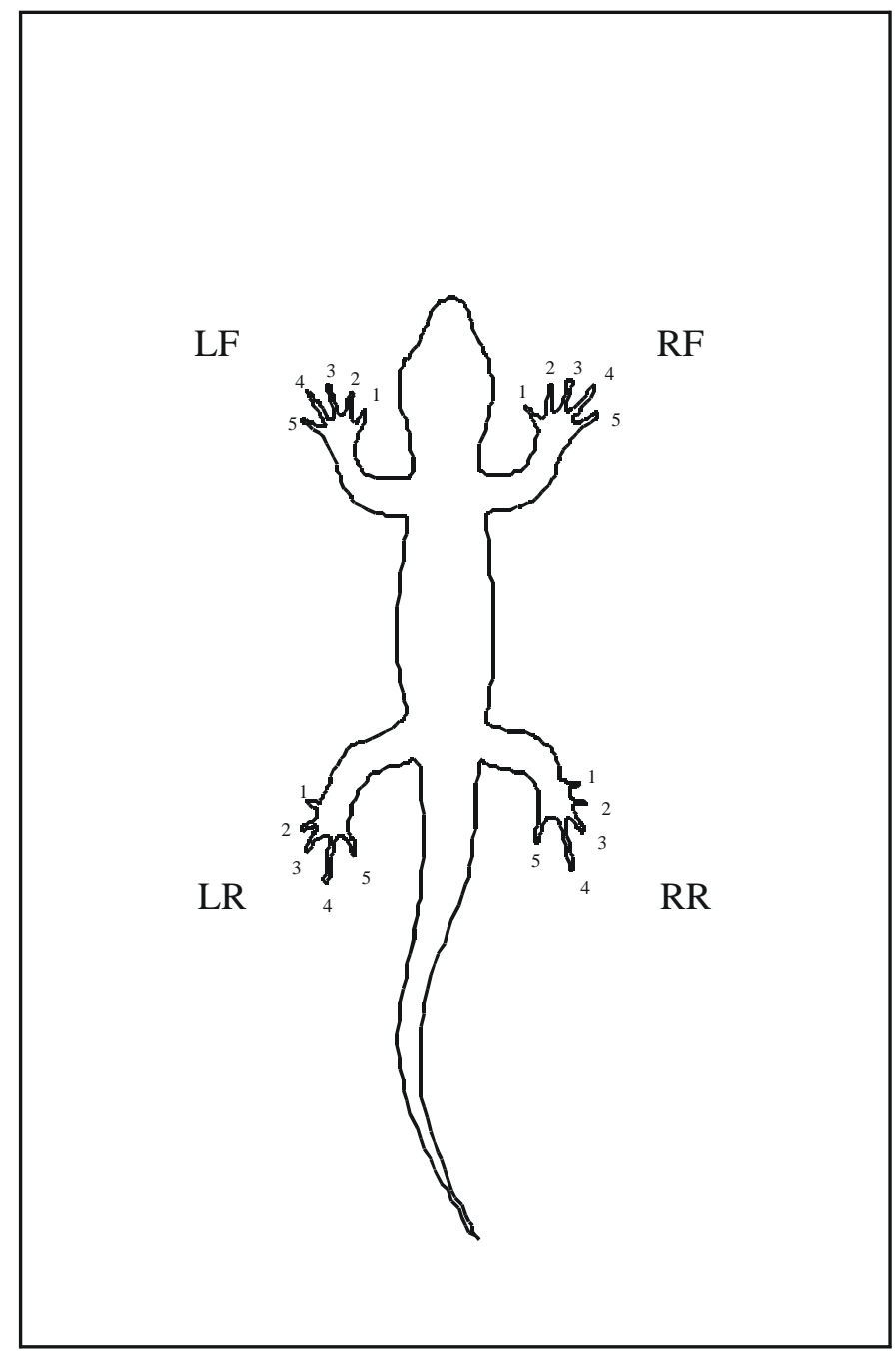

Figure I Dorsal view of skink; numbers indicate toe number. $(\mathrm{LF}=$ left front, $\mathrm{RF}=$ right front, $\mathrm{LR}=$ left rear, $\mathrm{RR}=$ right rear). 


\section{A)Green Island Female Oligosoma suteri, December 1999}

Table Ia Toe-clips used on female O. suteri taken from Green Island in December 1999. A list is present at the end of the table describing abbreviations used.

\begin{tabular}{|c|c|c|c|c|c|c|c|c|c|}
\hline No.M & T-C & FT & Natural & SVL & VTL & $\mathbf{R}$ & Mass & Date Laid & No.E \\
\hline 1 & 5555 & 5475 & 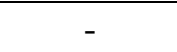 & 103 & 74 & 32 & 16.425 & 31-Dec-99 & 5 \\
\hline 2 & 5554 & 5476 & LR & 99 & 56 & 34 & 12.465 & 06-Jan-00 & 4 \\
\hline 3 & 5553 & 5480 & - & 92 & 78 & 30 & 11.08 & 13-Jan-00 & 3 \\
\hline 4 & 5552 & 5482 & - & 94 & 53 & 40 & 11.236 & 21-Dec-99 & 3 \\
\hline 5 & 5551 & 5510 & $\mathrm{RR}$ & 97 & 68 & $36(15)$ & 13.085 & 29-Dec-99 & 4 \\
\hline 6 & 5545 & 5481 & - & 93 & 67 & 28 & 10.989 & 03-Jan-00 & 4 \\
\hline 7 & 5544 & 5477 & $\mathrm{RR}$ & 96 & 34 & 24 & 10.13 & 16-Jan-00 & 2 \\
\hline 8 & 5543 & 5483 & - & 97 & 79 & 22 & 13.698 & 06-Jan-00 & 4 \\
\hline 9 & 5542 & 5484 & - & 98 & 82 & 36 & 11.778 & 03-Jan-00 & 3 \\
\hline 10 & 5535 & 5486 & - & 99 & 59 & 41 & 13.03 & 02-Jan-00 & 2 \\
\hline 11 & 5534 & 5488 & - & 91 & 89 & 6 & 10.74 & 02-Jan-00 & 3 \\
\hline 12 & 5533 & 5485 & $\mathrm{RR}$ & 103 & 88 & 44 & 14.428 & 06-Jan-00 & 5 \\
\hline 13 & 5532 & 5490 & - & 98 & 55 & 39 & 11.587 & 02-Jan-00 & 4 \\
\hline 14 & 5531 & 5491 & LR, RR & 96 & 83 & 39 & 12.726 & 08-Jan-00 & 4 \\
\hline 15 & 5525 & 5492 & - & 98 & 72 & 51 & 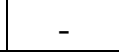 & - & - \\
\hline 16 & 5524 & 5489 & RR & 95 & 31 & 19 & 10.039 & 05-Jan-00 & 3 \\
\hline 17 & 5523 & 5494 & - & 97 & 87 & 33 & 12.629 & 06-Jan-00 & 3 \\
\hline 18 & 5522 & 5496 & - & 96 & 71 & 48 & 11.76 & 17-Jan-00 & 4 \\
\hline 19 & 5455 & 5497 & - & 99 & 74 & 37 & 13.694 & 02-Jan-00 & 3 \\
\hline 20 & $545(45)$ & 5500 & $\mathrm{RF}, \mathrm{RR}(4)$ & 90 & 92 & 18 & 10.434 & 29-Dec-99 & 4 \\
\hline 21 & 5454 & 5498 & $\mathrm{RR}$ & 102 & 48 & 35 & 13.42 & 15-Jan-00 & 4 \\
\hline 22 & 5453 & 5499 & - & 101 & 74 & 49 & 13.79 & 30-Dec-99 & 4 \\
\hline 23 & 5452 & 5501 & - & 90 & 85 & 23 & 11.728 & 31-Dec-99 & 3 \\
\hline 24 & 5445 & 5495 & LR & 102 & 65 & 46 & 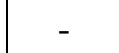 & - & - \\
\hline 25 & 5444 & 5502 & - & 99 & 105 & 12 & 12.89 & 03-Jan-00 & 4 \\
\hline 26 & 5443 & 5503 & - & 91 & 68 & 50 & 10.356 & 29-Dec-99 & 3 \\
\hline 27 & 5442 & 5504 & - & 95 & 76 & 24 & 11.042 & 29-Dec-99 & 5 \\
\hline 28 & 5435 & 5505 & - & 94 & 53 & 41 & 10.541 & 02-Jan-00 & 3 \\
\hline 29 & 5434 & 5506 & - & 97 & 79 & 28 & 12.518 & 01-Jan-00 & 4 \\
\hline 30 & 5433 & 5507 & LF & 100 & 41 & 27 & 10.946 & 03-Jan-00 & 4 \\
\hline 31 & 5432 & 5508 & - & 92 & 41 & 37 & 10.064 & 24-Dec-99 & 3 \\
\hline 32 & 5425 & 5509 & - & 95 & 55 & 48 & 11.56 & 06-Jan-00 & 3 \\
\hline 33 & 5424 & 5513 & - & 101 & 93 & c & 13.43 & 21-Jan-00 & 4 \\
\hline 34 & 5423 & 5514 & - & 93 & 43 & $28(7)$ & 10.193 & 02-Jan-00 & 3 \\
\hline 35 & 5422 & 5515 & - & 92 & 80 & 37 & 12.892 & 27-Dec-99 & 3 \\
\hline 36 & 5355 & 5487 & $\mathrm{RF}$ & 103 & 75 & 45 & 15.789 & 31-Dec-99 & 4 \\
\hline 37 & 5354 & 5493 & RF & 95 & 56 & 39 & 11.006 & 03-Jan-00 & 2 \\
\hline 38 & 5353 & 5517 & - & 96 & 37 & 0 & 12.396 & 08-Jan-00 & 4 \\
\hline 39 & 5352 & 5518 & - & 93 & 64 & 44 & 10.475 & 28-Dec-99 & 4 \\
\hline 40 & 5345 & 5516 & LR & 93 & 77 & 22 & 12.459 & 29-Dec-99 & 3 \\
\hline 41 & 5344 & 5520 & - & 95 & 64 & 33 & 12.282 & 03-Jan-00 & 4 \\
\hline 42 & 5343 & 5521 & - & 94 & 64 & 39 & 10.952 & 23-Dec-99 & 3 \\
\hline 43 & 5342 & 5522 & LF & 96 & 40 & 5 & 11.42 & 12-Jan-00 & 4 \\
\hline 44 & 5335 & 5519 & $\mathrm{RR}$ & 95 & 59 & 32 & 10.706 & 06-Jan-00 & 3 \\
\hline 45 & 5334 & 5524 & - & 99 & 73 & 47 & 15.341 & 04-Jan-00 & 4 \\
\hline
\end{tabular}




\begin{tabular}{|c|c|c|c|c|c|c|c|c|c|}
\hline No.M & T-C & FT & Natural & SVL & VTL & R & Mass & Date Laid & No.E \\
\hline 46 & 5333 & 5525 & - & 103 & 67 & 57 & 14.897 & 06-Jan-00 & 5 \\
47 & 5332 & 5526 & - & 95 & 66 & 55 & 12.462 & 05-Jan-00 & 4 \\
48 & 5325 & 5527 & RR & 97 & 56 & 41 & 13.16 & 17-Jan-00 & 3 \\
49 & 5255 & 5528 & RR & 102 & 65 & 48 & 13.543 & 06-Jan-00 & 4 \\
50 & 5254 & 5511 & LF, RF, RR & 101 & 45 & 26 & 14.398 & 04-Jan-00 & 4 \\
\hline 51 & 4455 & 5523 & RF & 96 & 47 & 32 & 11.616 & 08-Jan-00 & 4 \\
52 & 3555 & 5478 & LF & 97 & 67 & 46 & 12.19 & 03-Jan-00 & 4 \\
53 & 3554 & 5529 & LF & 97 & 57 & 41 & 12.05 & 14-Jan-00 & 3 \\
54 & 2555 & 5512 & LF & 92 & 78 & 32 & 11.319 & 09-Jan-00 & 4 \\
55 & 1555 & 5479 & LF & 100 & 76 & 42 & 14.684 & 07-Jan-00 & 4 \\
\hline 56 & foot_--- & - & LF & 97 & 64 & 31 & 12.257 & 31-Dec-99 & 4 \\
57 & foot_-- & - & RF & 90 & 95 & 10 & 10.937 & 6-Jan-00 & 4 \\
58 & -2_foot & - & RF, RR & 97 & 57 & 46 & 11.81 & 14-Jan-00 & 3 \\
59 & $--3(35)$ & - & LR, RR & 103 & 62 & 46 & 13.87 & 19-Jan-00 & 4 \\
60 & -- (345) & - & RR & 95 & 60 & 49 & 12.524 & 8-Jan-00 & 4 \\
& & & & & & & & & \\
\hline
\end{tabular}

\section{Abbreviations used}

\begin{tabular}{|c|c|c|}
\hline No.M & $=$ & an arbitrary number assigned to female. \\
\hline $\mathrm{T}-\mathrm{C}$ & $=$ & toe clip - read LF, RF, LR, RR viewed from dorsal surface (Figure \\
\hline & & $\mathrm{I}), \mathrm{LF}=$ left front, $\mathrm{RF}=$ right front, $\mathrm{LR}=$ left rear, $\mathrm{RR}=$ right rear. \\
\hline Natural & $=$ & toes, or feet, that were lost naturally and thus not toe-clipped. \\
\hline SVL & - & the length (mm) from snout to cloacal opening (vent). \\
\hline VTL & $=$ & $\begin{array}{l}\text { the length (mm) of the tail in its entirety from vent to tip (i.e. } \\
\text { including any regeneration). }\end{array}$ \\
\hline $\mathrm{R}$ & $=$ & $\begin{array}{l}\text { the length (mm) of tail regeneration. Numbers in brackets indicate } \\
\text { that there was more than one regeneration area; 'c' indicates that } \\
\text { tail was complete. }\end{array}$ \\
\hline Wt & - & the mass (g) of females immediately after oviposition. \\
\hline Date Laid & $=$ & the date the female oviposited. \\
\hline No.E & - & the number of eggs the female laid. \\
\hline Dash (-) & $=$ & not applicable. \\
\hline
\end{tabular}

The detached toes were assigned frozen tissue (FT) numbers and stored in Nuncs ${ }^{\mathrm{TM}}$ filled with $95 \%$ ethanol while on Green Island and put into an $-80^{\circ} \mathrm{C}$ freezer at VUW. The freshly clipped toes were dipped in Tricin ${ }^{\mathrm{TM}}$ powder (triple antibiotic powder: Bacitracin zinc, Neomysin sulphate and Polymyxin B sulphate) to prevent infection. Length measurements were obtained using a $300 \mathrm{~mm}$ clear plastic ruler and mass using a Sartørius top-loading balance. 


\section{B) Captive incubated and reared $O$. suteri}

Table Ib Toe-clips and hatching data for juvenile O. suteri incubated at constant incubation temperatures. A list is present at the end of the table describing abbreviations used.

\begin{tabular}{|c|c|c|c|c|c|c|c|c|c|c|c|}
\hline T-C & $\mathbf{T}$ & WP & SEX & SVL & TL & Wt & No.M & DateL & DateH & FT & Notes \\
\hline 5555 & 26 & -120 & $\mathrm{~F}$ & 32 & 74 & 0.679 & 40 & 29/12/99 & $9 / 2 / 00$ & 5575 & cod \\
\hline 5554 & 26 & -120 & M & 35 & 79 & 0.822 & 31 & 24/12/99 & $14 / 2 / 00$ & 5578 & \\
\hline 5553 & 26 & -120 & $\mathrm{~F}$ & 36 & 81 & 0.835 & 4 & 21/12/99 & $15 / 2 / 00$ & 5576 & \\
\hline 5552 & 26 & -270 & M & 29 & 63 & 0.416 & 35 & $2 / 1 / 00$ & $15 / 2 / 00$ & 5577 & \\
\hline 5545 & 26 & -270 & $\mathrm{~F}$ & 34 & 76 & 0.689 & 13 & $2 / 1 / 00$ & $23 / 2 / 00$ & 5560 & \\
\hline 5544 & 26 & -270 & M & 33 & 76 & 0.826 & 42 & $3 / 1 / 00$ & $17 / 2 / 00$ & $5555 / 85$ & \\
\hline 5543 & 26 & -120 & M & 31 & 73 & 0.799 & - & $18 / 2 / 00$ & $18 / 2 / 00$ & $5554 / 82$ & \\
\hline 5542 & 26 & -120 & $\mathrm{~F}$ & 38 & 84 & 0.859 & - & $18 / 2 / 00$ & $18 / 2 / 00$ & 5580 & \\
\hline 5535 & 26 & -270 & $\mathrm{~F}$ & 33 & 69 & 0.733 & 56 & $31 / 12 / 99$ & $18 / 2 / 00$ & 5581 & D26/07/00 \\
\hline 5534 & 26 & -120 & $\mathrm{~F}$ & 34 & 73 & 0.638 & 20 & 29/12/99 & $19 / 2 / 00$ & 5556 & \\
\hline 5533 & 26 & -120 & M & 34 & 81 & 0.701 & 20 & 19/2/00 & $19 / 2 / 00$ & 5553 & \\
\hline 5532 & 26 & -270 & $\mathrm{~F}$ & 34 & 74 & 0.683 & 27 & 29/12/99 & $19 / 2 / 00$ & 5557 & \\
\hline 5525 & 26 & -120 & $\mathrm{~F}$ & 35 & 79 & 0.777 & 22 & $30 / 12 / 99$ & $21 / 2 / 00$ & 5579 & \\
\hline 5524 & 26 & -270 & $\mathrm{~F}$ & 34 & 72 & 0.634 & 45 & $4 / 1 / 00$ & $21 / 2 / 00$ & 5552 & \\
\hline 5523 & 26 & -120 & M & 36 & 79 & 0.782 & 19 & $2 / 1 / 00$ & $21 / 2 / 00$ & 5558 & \\
\hline 5522 & 26 & -120 & $\mathrm{~F}$ & 35 & 80 & 0.794 & 9 & $3 / 1 / 00$ & $23 / 2 / 00$ & 5559 & \\
\hline 5455 & 26 & -120 & $\mathrm{M}$ & 34 & 79 & 0.781 & 34 & $2 / 1 / 00$ & $23 / 2 / 00$ & 5561 & \\
\hline 5454 & 26 & -120 & $\mathrm{~F}$ & 33 & 75 & 0.71 & 32 & $6 / 1 / 00$ & $23 / 2 / 00$ & 5562 & \\
\hline 5453 & 26 & -120 & M & 35 & 76 & 0.765 & 16 & $5 / 1 / 00$ & $24 / 2 / 00$ & 5563 & \\
\hline 5452 & 26 & -120 & $\mathrm{~F}$ & 34 & 80 & 0.767 & 63 & $3 / 1 / 00$ & $24 / 2 / 00$ & 5564 & \\
\hline 5445 & 26 & -270 & $\mathrm{~F}$ & 35 & 77 & 0.747 & 47 & $5 / 1 / 00$ & $25 / 2 / 00$ & 5565 & \\
\hline 5444 & 26 & -120 & $\mathrm{~F}$ & 35 & 79 & 0.777 & 2 & $6 / 1 / 00$ & $25 / 2 / 00$ & 5566 & \\
\hline 5443 & 26 & -120 & M & 36 & 81 & 0.837 & 41 & 29/12/99 & $25 / 2 / 00$ & 5567 & \\
\hline 5442 & 26 & -120 & $\mathrm{M}$ & 35 & 79 & 0.748 & 8 & $6 / 1 / 00$ & $25 / 2 / 00$ & 5568 & \\
\hline 5435 & 26 & -120 & $\mathrm{~F}$ & 35 & 78 & 0.76 & 46 & $6 / 1 / 00$ & $26 / 2 / 00$ & 5569 & \\
\hline 5434 & 26 & -270 & M & 35 & 76 & 0.752 & 49 & $6 / 1 / 00$ & $26 / 2 / 00$ & 5570 & \\
\hline 5433 & 26 & -270 & $\mathrm{~F}$ & 33 & 75 & 0.671 & 43 & $12 / 1 / 00$ & $2 / 3 / 00$ & 5587 & \\
\hline 5432 & 26 & -270 & M & 34 & 73 & 0.67 & 12 & $6 / 1 / 00$ & $26 / 2 / 00$ & 5572 & D13/3/00 \\
\hline 5425 & 26 & -120 & $\mathrm{M}$ & 36 & 80 & 0.763 & 50 & $4 / 1 / 00$ & $26 / 2 / 00$ & 5573 & \\
\hline 5424 & 26 & -120 & M & 36 & 79 & 0.81 & 51 & $8 / 1 / 00$ & $27 / 2 / 00$ & 5574 & \\
\hline 5423 & 26 & -270 & $\mathrm{M}$ & 35 & 78 & 0.765 & - & $27 / 2 / 00$ & $27 / 2 / 00$ & 5582 & \\
\hline 5422 & 26 & -270 & $\mathrm{~F}$ & 36 & 77 & 0.741 & 60 & $8 / 1 / 00$ & $28 / 2 / 00$ & 5585 & \\
\hline 5355 & 26 & -120 & $\mathrm{~F}$ & 34 & 77 & 0.746 & 54 & $9 / 1 / 00$ & $3 / 3 / 00$ & 5588 & \\
\hline 5354 & 26 & -270 & $\mathrm{~F}$ & 34 & 76 & 0.678 & 3 & $13 / 1 / 00$ & $3 / 3 / 00$ & 5589 & \\
\hline 5353 & 26 & -270 & M & 34.5 & 76 & 0.743 & 53 & $14 / 1 / 00$ & $4 / 3 / 00$ & 5590 & \\
\hline 5352 & 26 & -120 & M & 34.5 & 77 & 0.745 & 53 & $14 / 1 / 00$ & $6 / 3 / 00$ & 5591 & \\
\hline 5345 & 26 & -120 & $\mathrm{M}$ & 35 & 77 & 0.681 & 58 & $14 / 1 / 00$ & $6 / 3 / 00$ & 5592 & \\
\hline 5344 & 26 & -120 & M & 35 & 78 & 0.779 & 21 & 15/1/00 & $6 / 3 / 00$ & 5593 & \\
\hline 5343 & 26 & -120 & $\mathrm{~F}$ & 36 & 80 & 0.858 & 48 & $17 / 1 / 00$ & $7 / 3 / 00$ & 5594 & \\
\hline 5342 & 26 & -270 & $\mathrm{M}$ & 34 & 75 & 0.641 & 18 & 17/1/00 & $7 / 3 / 00$ & 5595 & \\
\hline 5335 & 26 & -270 & M & 36 & 77 & 0.762 & 57 & $6 / 1 / 00$ & $26 / 2 / 00$ & 5571 & \\
\hline 5334 & 26 & -270 & $\mathrm{~F}$ & 36 & 82 & 0.909 & 7 & $16 / 1 / 00$ & 9/3/00 & 5596 & \\
\hline 5333 & 26 & -270 & M & 35 & 78 & 0.806 & 59 & 19/1/00 & $10 / 3 / 00$ & 5597 & \\
\hline 5332 & 26 & -270 & M & 35 & 75 & 0.813 & 59 & 19/1/00 & $10 / 3 / 00$ & 5598 & \\
\hline
\end{tabular}




\begin{tabular}{|c|c|c|c|c|c|c|c|c|c|c|c|}
\hline T-C & $\mathbf{T}$ & WP & SEX & SVL & TL & Wt & No.M & DateL & DateH & FT & Notes \\
\hline 5325 & 26 & -270 & $F$ & 34 & 75 & 0.695 & 33 & $21 / 1 / 00$ & $12 / 3 / 00$ & 5599 & \\
\hline 5324 & 26 & -270 & M & 35 & 76 & 0.775 & 33 & $21 / 1 / 00$ & $12 / 3 / 00$ & 5600 & \\
\hline 5323 & 22 & -270 & $\mathrm{~F}$ & 28 & 60 & 0.336 & 35 & 27/12/99 & $7 / 3 / 00$ & 5601 & \\
\hline 5322 & 22 & -270 & $\mathrm{~F}$ & 36 & 79 & 0.835 & 1 & $31 / 12 / 99$ & $7 / 3 / 00$ & 5602 & \\
\hline 5255 & 22 & -120 & $\mathrm{~F}$ & 38 & 86 & 0.874 & - & $8 / 3 / 00$ & $8 / 3 / 00$ & 5603 & \\
\hline 5254 & 22 & -120 & M & 36 & 80 & 0.756 & - & $8 / 3 / 00$ & $8 / 3 / 00$ & 5604 & \\
\hline 5253 & 22 & -120 & $\mathrm{M}$ & 35 & 73 & 0.686 & 32 & $6 / 1 / 00$ & $9 / 3 / 00$ & 5605 & $\cos$ \\
\hline 5252 & 22 & -270 & $\mathrm{~F}$ & 37 & 86 & 0.815 & - & $11 / 3 / 00$ & $11 / 3 / 00$ & 5606 & \\
\hline 5245 & 22 & -270 & $\mathrm{~F}$ & 36 & 82 & 0.759 & - & $11 / 3 / 00$ & $11 / 3 / 00$ & 5607 & \\
\hline 5244 & 22 & -270 & M & 35 & 77 & 0.719 & 27 & 29/12/99 & $11 / 3 / 00$ & 5608 & \\
\hline 5243 & 22 & -270 & $\mathrm{~F}$ & 36 & 79 & 0.776 & 56 & $31 / 12 / 99$ & 13/3/00 & 5609 & \\
\hline 5242 & 22 & -270 & M & 36 & 83 & 0.857 & 26 & 29/12/99 & $13 / 3 / 00$ & 5610 & \\
\hline 5235 & 22 & -120 & $\mathrm{M}$ & 36 & 81 & 0.824 & - & $14 / 3 / 00$ & $14 / 3 / 00$ & 5611 & \\
\hline 5234 & 22 & -120 & M & 34 & 76 & 0.653 & - & $14 / 3 / 00$ & $14 / 3 / 00$ & 5612 & \\
\hline 5233 & 22 & -120 & $\mathrm{~F}$ & 37 & 83 & 0.921 & 23 & $31 / 12 / 99$ & $14 / 3 / 00$ & 5613 & \\
\hline 5232 & 22 & -120 & M & 36 & 79 & 0.758 & 34 & $21 / 1 / 00$ & $14 / 3 / 00$ & 5614 & \\
\hline 5225 & 22 & -270 & $\mathrm{M}$ & 35 & 78 & 0.761 & 28 & 29/12/99 & $14 / 3 / 00$ & 5615 & \\
\hline 5224 & 22 & -120 & M & 36 & 81 & 0.819 & - & $15 / 3 / 00$ & $15 / 3 / 00$ & 5616 & \\
\hline 5223 & 22 & -120 & $\mathrm{~F}$ & 37 & 84 & 0.885 & - & 15/3/00 & $15 / 3 / 00$ & 5617 & \\
\hline 5222 & 22 & -120 & $\mathrm{~F}$ & 36 & 79 & 0.783 & 25 & $3 / 1 / 00$ & $15 / 3 / 00$ & 5618 & \\
\hline 4555 & 26 & -120 & $\mathrm{~F}$ & 35 & 78 & 0.816 & 38 & $8 / 1 / 00$ & $27 / 2 / 00$ & 5584 & \\
\hline 4554 & 26 & -270 & $\mathrm{~F}$ & 36 & 79 & 0.794 & - & $27 / 2 / 00$ & $27 / 2 / 00$ & 5583 & \\
\hline 4553 & 26 & -270 & M & 34 & 78 & 0.693 & 14 & $8 / 1 / 00$ & $29 / 2 / 00$ & 5586 & \\
\hline 4552 & 22 & -270 & $\mathrm{~F}$ & 34 & 74 & 0.595 & 13 & $2 / 1 / 00$ & $15 / 3 / 00$ & 5619 & \\
\hline 4544 & 22 & -120 & $\mathrm{~F}$ & 35 & 76 & 0.703 & 22 & $30 / 12 / 99$ & $16 / 3 / 00$ & 5620 & \\
\hline 4543 & 22 & -270 & M & 35 & 77 & 0.755 & 45 & $4 / 1 / 00$ & $16 / 3 / 00$ & 5621 & \\
\hline 4542 & 22 & -120 & M & 36 & 75 & 0.804 & 19 & $2 / 1 / 00$ & $16 / 3 / 00$ & 5622 & \\
\hline 4535 & 22 & -120 & $\mathrm{M}$ & 37 & 81 & 0.786 & 16 & $5 / 1 / 00$ & $17 / 3 / 00$ & 5623 & \\
\hline 4534 & 22 & -120 & $\mathrm{M}$ & 35 & 80 & 0.795 & 8 & $6 / 1 / 00$ & $17 / 3 / 00$ & 5624 & \\
\hline 4533 & 22 & -120 & $\mathrm{~F}$ & 35 & 79 & 0.776 & 20 & 29/12/99 & $17 / 3 / 00$ & 5625 & \\
\hline 4532 & 22 & -120 & $\mathrm{~F}$ & 35 & 78 & 0.744 & 9 & $3 / 1 / 00$ & 17/3/00 & 5626 & $\mathrm{D} 15 / 07 / 00$ \\
\hline 4525 & 22 & -120 & $\mathrm{~F}$ & 36 & 79 & 0.791 & 6 & $3 / 1 / 00$ & $17 / 3 / 00$ & 5627 & \\
\hline 4524 & 22 & -120 & $\mathrm{~F}$ & 37 & 83 & 0.858 & 50 & $4 / 1 / 00$ & 18/3/00 & 5628 & \\
\hline 4523 & 22 & -120 & $\mathrm{~F}$ & 36.5 & 80 & 0.788 & 46 & $6 / 1 / 00$ & $18 / 3 / 00$ & 5629 & \\
\hline 4522 & 22 & -270 & $\mathrm{~F}$ & 37 & 81 & 0.821 & 52 & $3 / 1 / 00$ & $18 / 3 / 00$ & 5630 & \\
\hline 4455 & 22 & -270 & $\mathrm{~F}$ & 35.5 & 78 & 0.776 & 49 & $17 / 1 / 00$ & $19 / 3 / 00$ & 5631 & \\
\hline 4454 & 22 & -270 & $\mathrm{~F}$ & 35 & 78 & 0.77 & 55 & $7 / 1 / 00$ & 19/3/00 & 5632 & \\
\hline 4453 & 22 & -270 & M & 36 & 83 & 0.782 & 47 & $5 / 1 / 00$ & $19 / 3 / 00$ & 5633 & \\
\hline 4452 & 22 & -120 & $\mathrm{~F}$ & 36 & 79 & 0.773 & 51 & $8 / 1 / 00$ & $20 / 3 / 00$ & 5634 & \\
\hline 4444 & 22 & -270 & $\mathrm{M}$ & 35 & 77 & 0.785 & 57 & $6 / 1 / 00$ & $20 / 3 / 00$ & 5635 & \\
\hline 4443 & 22 & -270 & $\mathrm{~F}$ & 35 & 77 & 0.745 & 44 & $6 / 1 / 00$ & $21 / 3 / 00$ & 5636 & \\
\hline 4442 & 22 & -120 & $\mathrm{M}$ & 35 & 78 & 0.766 & 38 & $8 / 1 / 00$ & $21 / 3 / 00$ & 5637 & \\
\hline 4435 & 22 & -270 & $\mathrm{M}$ & 34 & 75 & 0.737 & 29 & $2 / 1 / 00$ & $22 / 3 / 00$ & 5638 & \\
\hline 4434 & 22 & -270 & $\mathrm{~F}$ & 33 & 72 & 0.63 & 53 & $14 / 1 / 00$ & $22 / 3 / 00$ & 5639 & \\
\hline 4433 & 22 & -270 & M & 34 & 71 & 0.739 & 14 & $8 / 1 / 00$ & $26 / 3 / 00$ & 5642 & \\
\hline 4432 & 22 & -270 & M & 34 & 74 & 0.709 & 43 & $12 / 1 / 00$ & $26 / 3 / 00$ & 5643 & \\
\hline 4425 & 22 & -270 & $\mathrm{M}$ & 35.5 & 80 & 0.758 & 60 & $8 / 1 / 00$ & $27 / 3 / 00$ & 5644 & \\
\hline 4424 & 22 & -120 & M & 34 & 75 & 0.759 & 21 & 15/1/00 & $27 / 3 / 00$ & 5645 & \\
\hline 4423 & 22 & -270 & $\mathrm{~F}$ & 36 & 79 & 0.744 & 3 & $13 / 1 / 00$ & $28 / 3 / 00$ & 5646 & \\
\hline 4422 & 22 & -270 & $\mathrm{~F}$ & 35 & 76 & 0.747 & 18 & 17/1/00 & 28/3/00 & 5647 & \\
\hline
\end{tabular}




\begin{tabular}{|c|c|c|c|c|c|c|c|c|c|c|c|}
\hline T-C & $\mathbf{T}$ & WP & SEX & SVL & TL & Wt & No.M & DateL & DateH & FT & Notes \\
\hline 4355 & 22 & -120 & $\mathrm{M}$ & 34.5 & 79 & 0.814 & 54 & $9 / 1 / 00$ & $29 / 3 / 00$ & 5648 & \\
\hline 4354 & 22 & -120 & M & 35 & 77 & 0.82 & 58 & $14 / 1 / 00$ & $30 / 3 / 00$ & 5650 & \\
\hline 4353 & 22 & -120 & M & 35.5 & 80 & 0.828 & 48 & $5 / 1 / 00$ & $30 / 3 / 00$ & 5651 & \\
\hline 4345 & 22 & -270 & $\mathrm{~F}$ & 35 & 78 & 0.802 & 59 & 19/1/00 & $2 / 4 / 00$ & 5652 & D31/01/01 \\
\hline 4344 & 22 & -270 & M & 34 & 75 & 0.746 & 33 & $21 / 1 / 00$ & $2 / 4 / 00$ & 5653 & \\
\hline 4343 & 18 & -270 & M & 34 & 75 & 0.74 & 5 & 29/12/99 & $4 / 5 / 00$ & 5655 & cod; D19/5/00 \\
\hline 4335 & 18 & -270 & M & 34 & 75 & 0.78 & 1 & $31 / 12 / 99$ & $15 / 5 / 00$ & 5659 & $\mathrm{D} 26 / 5 / 00$ \\
\hline 4334 & $18 / 22$ & -120 & M & 35 & 77 & 0.71 & 31 & $1 / 1 / 00$ & $15 / 5 / 00$ & 5660 & D26/5/00 \\
\hline 4333 & $18 / 22$ & -270 & $\mathrm{~F}$ & 35 & 76 & 0.712 & 27 & 29/12/99 & $15 / 5 / 00$ & 5661 & \\
\hline 4325 & $18 / 22$ & -120 & F & 37 & 81 & 0.837 & 4 & 21/12/99 & $15 / 5 / 00$ & 5662 & \\
\hline 4324 & $18 / 22$ & -120 & $\mathrm{~F}$ & 36 & 78 & 0.852 & 23 & 31/12/99 & $15 / 5 / 00$ & 5663 & $\cos$ \\
\hline 4323 & $18 / 22$ & -120 & M & 33 & 76 & 0.728 & 40 & $8 / 1 / 00$ & $16 / 5 / 00$ & 5664 & D28/03/01 \\
\hline 4255 & $18 / 22$ & -120 & $\mathrm{~F}$ & 32 & 71 & 0.74 & 17 & $6 / 1 / 00$ & $16 / 5 / 00$ & 5665 & cos; D25/5/00 \\
\hline 4254 & $18 / 22$ & -120 & M & 35 & 73 & 0.712 & 46 & $4 / 1 / 00$ & $17 / 5 / 00$ & 5666 & $\mathrm{D} 10 / 12 / 00$ \\
\hline 4253 & $18 / 22$ & -120 & M & 33 & 70 & 0.694 & 38 & 27/12/99 & $17 / 5 / 00$ & 5667 & \\
\hline 4252 & $18 / 22$ & -120 & $\mathrm{~F}$ & 34 & 74 & 0.749 & 32 & 24/12/99 & $18 / 5 / 00$ & 5669 & $\cos$ \\
\hline 4245 & $18 / 22$ & -120 & $\bar{M}$ & 35 & 71 & 0.731 & 51 & $4 / 1 / 00$ & $18 / 5 / 00$ & 5670 & $\cos$ \\
\hline 4244 & $18 / 22$ & -270 & $\mathrm{~F}$ & 33 & 71 & 0.702 & 47 & $6 /$ & 00 & 5671 & D30/6/00 \\
\hline 4243 & $18 / 22$ & -270 & M & 32 & 76 & 0.602 & 12 & $6 / 1 / 00$ & /00 & 5672 & $\mathrm{D} ? / 11 / 00$ \\
\hline 4242 & $18 / 22$ & -120 & M & 34 & 75 & 0.75 & 9 & $3 / 1 / 00$ & $19 / 5 / 00$ & 5673 & D28/5/00 \\
\hline 4235 & $18 / 22$ & -270 & $\mathrm{M}$ & 35 & 75 & 0.767 & 56 & $31 / 12 / 99$ & $20 / 5 / 00$ & 5674 & D13/12/00 \\
\hline 4234 & $18 / 22$ & -120 & $\mathrm{~F}$ & 35 & 77 & 0.823 & 50 & $6 / 1 / 00$ & $/ 00$ & 5675 & \\
\hline 4233 & $18 / 22$ & -270 & M & 36 & 81 & 0.891 & 42 & 23/12/99 & $20 / 5 / 00$ & 5676 & D11/8/00 \\
\hline 4232 & $18 / 22$ & -270 & M & 33 & 70 & 0.632 & 57 & $6 / 1 / 00$ & $21 / 5 / 00$ & 5677 & \\
\hline 4225 & 18 & -270 & M & 34 & 75 & 0.718 & 45 & & 00 & 5679 & \\
\hline 4224 & 18 & -120 & M & 34 & 73 & 0.75 & 25 & $3 /$ & /00 & 5680 & cos; D7/6/00 \\
\hline 4223 & 18 & -120 & $\mathrm{~F}$ & 34 & 76 & 0.76 & 19 & $2 / 1 / 00$ & /00 & 5681 & cos; D9/6/00 \\
\hline 4222 & 18 & -120 & $\mathrm{~F}$ & 33 & 75 & 0.74 & 20 & 29/12/99 & $23 / 5 / 00$ & 5682 & cos; D11/6/00 \\
\hline 3555 & 18 & & $\mathrm{~F}$ & 34 & 73 & 0.785 & 8 & & & 5683 & $\mathrm{D} 15 / 6 / 00$ \\
\hline 3554 & $18 / 22$ & -270 & $\mathrm{~F}$ & 33 & 71 & 0.794 & 53 & $3 / 1 / 00$ & $24 / 5 / 00$ & 5684 & $\cos$ \\
\hline 3552 & $18 / 22$ & -270 & M & 33 & 70 & 0.723 & 43 & 23/12/99 & $24 / 5 / 00$ & 5685 & cos; D28/7/00 \\
\hline 3544 & $18 / 22$ & -270 & $\mathrm{M}$ & 34 & 71 & 0.781 & 18 & 17/1/00 & $25 / 5 / 00$ & 5686 & \\
\hline 3543 & 18 & -270 & $\mathrm{~F}$ & 33 & 73 & 0.61 & 13 & & $25 / 5 / 00$ & 5690 & cos; D2/6/00 \\
\hline 3542 & 18 & -120 & M & 34 & 75 & 0.754 & 2 & $6 / 1 / 00$ & $26 / 5 / 00$ & 5691 & D10/12/00 \\
\hline 3535 & 18 & -270 & $\mathrm{M}$ & 34 & 73 & 0.775 & 52 & $8 / 1 / 00$ & $27 / 5 / 00$ & 5693 & cos; D13/12/00 \\
\hline 3534 & $18 / 22$ & -120 & $\mathrm{~F}$ & 35 & 74 & 0.728 & 58 & $14 / 1 / 00$ & 29/5/00 & 5696 & $\mathrm{D} 12 / 2 / 00$ \\
\hline 3533 & 18 & -120 & M & 35 & 74 & 0.823 & 6 & $3 / 1 / 00$ & $30 / 5 / 00$ & 5697 & $\mathrm{D} 14 / 6 / 00$ \\
\hline 3532 & $18 / 22$ & -120 & $\mathrm{~F}$ & 34 & 71 & 0.68 & 33 & $6 / 1 / 00$ & $30 / 5 / 00$ & 5698 & $\mathrm{D} 27 / 10 / 00$ \\
\hline 3525 & 18 & -270 & $\bar{M}$ & 34 & 75 & 0.739 & 44 & $12 / 1 / 00$ & $31 / 5 / 00$ & 5700 & $\mathrm{D} 9 / 8 / 00$ \\
\hline 3524 & 18 & -270 & M & 32 & 67 & 0.692 & 59 & 19/1/00 & $3 / 6 / 00$ & 5702 & \\
\hline 3523 & 18 & -120 & $\mathrm{~F}$ & 35 & 77 & 0.735 & 21 & $15 / 1 / 00$ & $4 / 6 / 00$ & 5703 & \\
\hline
\end{tabular}

\section{Abbreviations used}

T-C = toe clip - read RF, LF, RR, LR viewed from dorsal surface (Figure I), RF = right front, $\mathrm{LF}=$ left front, $\mathrm{RR}=$ right rear, $\mathrm{LR}=$ left rear.

$\mathrm{T}=$ temperature $\left({ }^{\circ} \mathrm{C}\right)$ that individual was incubated.

WP $=$ water potential $(\mathrm{kPa})$ that individual was incubated.

Sex $\quad=$ sex of individual; $\mathrm{F}=$ female, $\mathrm{M}=$ male. 
SVL = the length (mm) from snout to cloacal opening (vent) at hatching.

$\mathrm{TL}=$ the length $(\mathrm{mm})$ from snout to tail tip at hatching.

$\mathrm{Wt}=$ the mass $(\mathrm{g})$ without umbilical cord etc. at hatching.

DateL $=$ the date the egg was laid.

DateH $=$ the date the juvenile hatched.

FT $\quad=$ frozen tissue number(s) assigned to individual.

$\cos =$ cut out of egg as sweating for at least 2 days.

cod $=$ cut out of egg to check on development.

$\mathrm{D}<$ date $>=$ individual died on $<$ date $>$.

Dash (-) $\quad=$ not applicable/not determinable.

Dates are all written day/month/year. 


\section{APPENDIX II}

\section{Histology}

\section{A) Fixation and storage}

\section{Eggs}

Two eggs were fixed immediately after oviposition to determine the embryonic stage at oviposition. This entailed:

1) Soaking in fixative; $50 \mathrm{~g}$ picric acid, $850 \mathrm{ml}$ Diethylene dioxide (1,4-Dioxan $\left.\mathrm{CH}_{2} \cdot \mathrm{CH}_{2} \cdot \mathrm{O} .\left(\mathrm{CH}_{2}\right)_{2} \cdot \mathrm{O}\right), 100 \mathrm{ml}$ formalin, $50 \mathrm{ml}$ Formic acid (two days).

2) Storing in dioxan.

Any eggs that dehydrated or went mouldy were assigned FT numbers and frozen at $80^{\circ} \mathrm{C}$ (Sanyo ${ }^{\mathrm{TM}}$ Vip series $\left.-86^{\circ} \mathrm{C}\right)$.

\section{Embryos and hatchlings}

Fully developed embryos and hatchlings that died naturally were preserved by:

1. Cutting into the abdominal cavity through ventral skin (embryo tails also removed),

2. Fixing specimen in neutral buffered formalin; $100 \mathrm{ml}$ Formaldehyde solution (37-40\%); $900 \mathrm{ml}$ distilled water, $4 \mathrm{~g} \mathrm{NaH} \mathrm{PO}_{4} \cdot \mathrm{H}_{2} \mathrm{O}, 6.5 \mathrm{~g} \mathrm{NaHPO}_{4}$ (three days),

3. Storing in $70 \%$ ethanol.

Eggshell, egg fluid and tails were assigned FT numbers and frozen at $-80^{\circ} \mathrm{C}$. 


\section{B) Embedding}

Before embedding was undertaken, the position of gonads was determined with the use of a dissecting microscope (Olympus ${ }^{\mathrm{TM}}$ model SD-ILK, SD30). The specimen was then severed about $2 \mathrm{~mm}$ below the cloacal opening and about $1 \mathrm{~mm}$ above the gonad. The section containing the gonads was labelled and stored in $70 \%$ ethanol in soda glass specimen tubes $(50 \times 18 \mathrm{~mm})$. The head and thorax section (and complete juveniles that died after 4 months of age) were stored in $70 \%$ ethanol, whilst the hind legs and tail were discarded. The sectioned piece containing the gonads was then embedded.

\section{Detailed embedding schedule}

Soak specimens separately in vials of solution:

1. $70-80 \%$ ethanol (one hour),

2. $80-95 \%$ ethanol (two hours),

3. $95 \%$ ethanol (two hours),

4. absolute ethanol (two hours),

5. $1 / 2$ absolute ethanol and $1 / 2$ xylol mixture (two hours),

6. concentrated xylol (two hours),

7. fresh concentrated xylol (two hours),

8. $1 / 2$ xylol and $1 / 2$ wax mixture (two hours),

9. pure wax (cooled at room temperature over night).

The following day the specimens in wax (Paraplast tissue embedding medium, $56^{\circ} \mathrm{C}$ ) were reheated in a Contherm oven to melting $\left(56^{\circ} \mathrm{C}\right)$. The specimens were then lodged in a wax capsule on a pine block using cooled copper elbows. A paper label was stuck between the wax capsule containing the specimen, and the pine block. 


\section{C) Sectioning and staining}

\section{Sectioning of block}

The embedded block of tissue was sectioned to $7 \mu \mathrm{m}$ using a metal wedge microtome.

The sections were floated in a warm water bath, below the temperature to melt wax, and onto a slide. The slides were dried in a $30^{\circ} \mathrm{C}$ Contherm oven for at least two days, and then stained with Haematoxylin and Eosin.

\section{Detailed staining schedule for light microscopy}

Soak slides in baths of solution:

1. histoclear (five minutes),

2. $100 \%$ isopropanol (three minutes),

3. $100 \%$ isopropanol (three minutes),

For the rest of the staining process, the slides were put into an automated staining machine (Shandon Elliott), which soaked slides in the following baths of solution:

4. 70\% isopropanol (two minutes),

5. 50\% isopropanol (two minutes),

6. distilled water (two minutes),

7. Delafield's Haematoxylin (20 minutes),

8. tap water (three minutes),

9. acid/alcohol mix - $1 \% \mathrm{HCl}$ and $95 \%$ ethanol (10 seconds),

10. salt/water mix - tap water and 20 drops of lithium carbonate (three minutes),

11. aqueous eosin (five minutes),

12. tap water (five minutes),

13. $95 \%$ isopropanol (one minute),

14. $95 \%$ isopropanol (two minutes),

15. $100 \%$ isopropanol (two minutes),

16. $100 \%$ isopropanol (two minutes),

17. histoclear (two minutes),

18. histoclear (seven minutes).

After staining, slides were mounted using duplex mounting media and various sized cover slips. 


\section{APPENDIX III}

\section{Results from statistical analyses}

\section{A) Chapter 2 results}

Table IIIa Results from statistical analyses of maternal effects, incubation period and egg mass. A list is present on page 74 describing abbreviations used.

\begin{tabular}{|c|c|c|c|c|c|c|c|}
\hline Test & $\begin{array}{c}\text { Independent } \\
\text { Variable }\end{array}$ & $\begin{array}{c}\text { Dependent } \\
\text { Variable }\end{array}$ & Covariate & dff & $\begin{array}{l}\text { Mean } \\
\text { Square }\end{array}$ & $\begin{array}{c}\text { F- } \\
\text { statistic }\end{array}$ & $\begin{array}{c}\text { p- } \\
\text { value }\end{array}$ \\
\hline \multirow{3}{*}{$\begin{array}{l}\text { Maternal } \\
\text { effects } \\
\text { (ANOVA) }\end{array}$} & Maternal SVL & $\begin{array}{l}\text { Mean egg } \\
\text { mass }\end{array}$ & - & 1 & 8.696 & 0.827 & 0.367 \\
\hline & Maternal SVL & $\begin{array}{l}\text { Number of } \\
\text { eggs }\end{array}$ & - & 3 & 62.901 & 5.981 & 0.001 \\
\hline & $\begin{array}{c}\text { Number of } \\
\text { eggs }\end{array}$ & $\begin{array}{c}\text { Mean egg } \\
\text { mass }\end{array}$ & - & 3 & $8.781^{-03}$ & 1.085 & 0.363 \\
\hline \multirow{4}{*}{$\begin{array}{c}\text { Incubation } \\
\text { Period } \\
\text { (univariate } \\
\text { GLM) }\end{array}$} & $\begin{array}{l}\text { Incubation } \\
\text { regime }\end{array}$ & $\begin{array}{c}\text { Days until } \\
\text { hatching }\end{array}$ & $\begin{array}{c}\text { Initial egg } \\
\text { mass }\end{array}$ & 1 & 7.897 & 0.577 & 0.449 \\
\hline & $\begin{array}{l}\text { Incubation } \\
\text { temperature }\end{array}$ & "“ & "“ & 2 & 78253.848 & 5715.287 & $<0.001$ \\
\hline & $\begin{array}{c}\text { Water } \\
\text { potential }\end{array}$ & “" & “" & 1 & 6.808 & 0.497 & 0.482 \\
\hline & $\begin{array}{c}\text { Incubation } \\
\text { temperature } \times \\
\text { water } \\
\text { potential }\end{array}$ & “ & “ & 2 & 1.651 & 0.121 & 0.887 \\
\hline \multirow{4}{*}{$\begin{array}{l}\text { Change in } \\
\text { Egg Mass } \\
\text { Over } \\
\text { Incubation } \\
\text { Period } \\
\text { (ANOVA) }\end{array}$} & $\begin{array}{l}\text { Incubation } \\
\text { regime }\end{array}$ & $\begin{array}{l}\text { Change in } \\
\text { egg mass }\end{array}$ & $\begin{array}{l}\text { Initial egg } \\
\text { mass }\end{array}$ & 1 & 0.706 & 5.819 & 0.017 \\
\hline & $\begin{array}{l}\text { Incubation } \\
\text { temperature }\end{array}$ & " & “" & 2 & 1.037 & 8.551 & $<0.001$ \\
\hline & $\begin{array}{c}\text { Water } \\
\text { potential }\end{array}$ & “ & “" & 1 & 4.143 & 34.150 & $<0.001$ \\
\hline & $\begin{array}{c}\text { Incubation } \\
\text { temperature } \times \\
\text { water } \\
\text { potential }\end{array}$ & “ & “ & 2 & 0.343 & 2.828 & 0.062 \\
\hline
\end{tabular}


Table IIIb Results from statistical analysis of hatching success. A list is present on page 74 describing abbreviations used.

\begin{tabular}{|c|c|c|c|c|c|c|c|}
\hline Test & $\begin{array}{c}\text { Independent } \\
\text { Variable }\end{array}$ & $\begin{array}{c}\text { Dependent } \\
\text { Variable }\end{array}$ & Covariate & df & $\begin{array}{l}\text { Residual } \\
\text { Deviance }\end{array}$ & $\chi^{2}$ & $\begin{array}{c}\text { p- } \\
\text { value }\end{array}$ \\
\hline \multirow{6}{*}{$\begin{array}{l}\text { Hatching } \\
\text { Success } \\
\text { (logistic } \\
\text { regression) }\end{array}$} & $\begin{array}{l}\text { Incubation } \\
\text { temperature }\end{array}$ & Hatch or not & - & $\overline{1771,2}$ & 1777.1 & 8.020 & 0.018 \\
\hline & $\begin{array}{c}\text { Water } \\
\text { potential }\end{array}$ & “" & - & 172,1 & 184.3 & 0.828 & 0.363 \\
\hline & $\begin{array}{c}\text { Initial egg } \\
\text { mass }\end{array}$ & “ & - & 172,1 & 184.2 & 0.983 & 0.322 \\
\hline & $\begin{array}{c}\text { Incubation } \\
\text { temperature } \times \\
\text { water } \\
\text { potential }\end{array}$ & “ & - & 170,3 & 176.3 & 0.878 & 0.349 \\
\hline & $\begin{array}{c}\text { Incubation } \\
\text { temperature } \times \\
\text { initial egg } \\
\text { mass }\end{array}$ & “ & - & 170,3 & 176.1 & 1.059 & 0.303 \\
\hline & $\begin{array}{c}\text { Incubation } \\
\text { temperature } \times \\
\text { water } \\
\text { potential } \times \\
\text { initial egg } \\
\text { mass }\end{array}$ & “ & - & 169,4 & 175.3 & 0.935 & 0.386 \\
\hline
\end{tabular}




\section{B) Chapter 3 results}

Table IIIc Results from statistical analysis of hatchling size and condition index. A list is present on page 74 describing abbreviations used.

\begin{tabular}{|c|c|c|c|c|c|c|c|}
\hline Test & $\begin{array}{c}\text { Independent } \\
\text { Variable }\end{array}$ & $\begin{array}{l}\text { Dependent } \\
\text { Variable }\end{array}$ & Covariates & df & $\begin{array}{l}\text { Mean } \\
\text { Square }\end{array}$ & $\begin{array}{c}\text { F- } \\
\text { statistic }\end{array}$ & p-value \\
\hline \multirow{17}{*}{$\begin{array}{c}\text { Hatchling Size } \\
\text { (multivariate } \\
\text { GLM) }\end{array}$} & Sex & Size measures & $\begin{array}{l}\text { Initial egg } \\
\text { mass }\end{array}$ & 4 & - & 0.232 & 0.920 \\
\hline & \multirow{4}{*}{$\begin{array}{l}\text { Incubation } \\
\text { temperature }\end{array}$} & SVL & “" & 2 & 18.086 & 29.966 & $<0.001$ \\
\hline & & VTL & “ & 2 & 91.325 & 21.986 & $<0.001$ \\
\hline & & TL & “ & 2 & 182.534 & 31.823 & $<0.001$ \\
\hline & & $\mathrm{Wt}$ & “ & 2 & $1.094^{-02}$ & 5.087 & 0.008 \\
\hline & \multirow{4}{*}{$\begin{array}{c}\text { Water } \\
\text { potential }\end{array}$} & SVL & "“ & 1 & 4.627 & 6.900 & 0.010 \\
\hline & & VTL & “" & 1 & 36.899 & 8.883 & 0.004 \\
\hline & & TL & “" & 1 & 67.660 & 11.796 & 0.001 \\
\hline & & $\mathrm{Wt}$ & “ & 1 & $1.664^{-02}$ & 7.742 & 0.006 \\
\hline & \multirow{4}{*}{$\begin{array}{l}\text { Incubation } \\
\text { regime }\end{array}$} & SVL & “ & 1 & 38.385 & 57.233 & $<0.001$ \\
\hline & & VTL & “" & 1 & 60.711 & 14.616 & $<0.001$ \\
\hline & & $\mathrm{TL}$ & “ & 1 & 195.645 & 34.109 & $<0.001$ \\
\hline & & $\mathrm{Wt}$ & “ & 1 & 0.153 & 71.125 & $<0.001$ \\
\hline & \multirow{4}{*}{$\begin{array}{l}\text { Incubation } \\
\text { temperature } \\
\times \text { water } \\
\text { potential }\end{array}$} & SVL & “" & 2 & 0.294 & 0.439 & 0.646 \\
\hline & & VTL & “ & 2 & 6.912 & 1.664 & 0.194 \\
\hline & & $\mathrm{TL}$ & “" & 2 & 4.855 & 0.846 & 0.432 \\
\hline & & $\mathrm{Wt}$ & “ & 2 & $5.601^{-05}$ & 0.026 & 0.974 \\
\hline \multirow{4}{*}{$\begin{array}{c}\text { Change in } \\
\text { Condition } \\
\text { Index Over } \\
\text { Four Months } \\
\text { (ANOVA) }\end{array}$} & $\begin{array}{l}\text { Incubation } \\
\text { temperature }\end{array}$ & $\begin{array}{l}\text { Change in } \\
\text { condition }\end{array}$ & $\begin{array}{c}\text { Initial egg } \\
\text { mass }\end{array}$ & $\overline{20}$ & $9.407^{-05}$ & $\begin{array}{c}51.913 \\
\end{array}$ & $2<0.001$ \\
\hline & $\begin{array}{c}\text { Water } \\
\text { potential }\end{array}$ & “" & “" & 1 & $2.720^{-06}$ & 1.501 & 0.223 \\
\hline & $\begin{array}{l}\text { Incubation } \\
\text { regime }\end{array}$ & “" & “" & 1 & $1.424^{-06}$ & 0.777 & 0.380 \\
\hline & $\begin{array}{l}\text { Incubation } \\
\text { temperature } \\
\times \text { water } \\
\text { potential }\end{array}$ & " & "“ & 2 & $4.149^{-07}$ & 0.229 & 0.796 \\
\hline
\end{tabular}


Table IIId Results from statistical analysis of growth and locomotor performance. A list is present on page 74 describing abbreviations used.

\begin{tabular}{|c|c|c|c|c|c|c|c|}
\hline Test & $\begin{array}{c}\text { Within- } \\
\text { subject } \\
\text { Variables }\end{array}$ & $\begin{array}{l}\text { Between- } \\
\text { subject } \\
\text { Variable }\end{array}$ & Covariates & df & $\begin{array}{l}\text { Mean } \\
\text { Square }\end{array}$ & $\begin{array}{c}\text { F- } \\
\text { statistic }\end{array}$ & $\begin{array}{c}\text { p- } \\
\text { value }\end{array}$ \\
\hline \multirow{13}{*}{$\begin{array}{l}\text { Growth to } \\
\text { Four Months } \\
\text { (repeated } \\
\text { measures } \\
\text { GLM) }\end{array}$} & $\begin{array}{c}\text { Month } \\
\text { measures }\end{array}$ & \multirow[t]{5}{*}{$\begin{array}{l}\text { Incubation } \\
\text { temperature }\end{array}$} & \multirow{5}{*}{$\begin{array}{l}\text { Hatchling } \\
\text { size (SVL, } \\
\text { VTL, TL, } \\
\text { Wt) }\end{array}$} & 18 & - & 10150.399 & $2<0.001$ \\
\hline & & & & 2 & 286.671 & & $<0.001$ \\
\hline & VTL & & & 2 & 1087.590 & 143.612 & $<0.001$ \\
\hline & $\mathrm{TL}$ & & & 2 & 2487.917 & 180.102 & $<0.001$ \\
\hline & $\mathrm{Wt}$ & & & 2 & 286.671 & 150.399 & $<0.001$ \\
\hline & \multirow[t]{8}{*}{$\begin{array}{c}\text { Month } \\
\text { measures }\end{array}$} & $\begin{array}{c}\text { Water } \\
\text { potential }\end{array}$ & " & 9 & - & 1.786 & 0.067 \\
\hline & & Sex & “" & 9 & - & 0.599 & 0.798 \\
\hline & & $\begin{array}{c}\text { Initial egg } \\
\text { mass }\end{array}$ & “" & 9 & - & 1.784 & 0.069 \\
\hline & & $\begin{array}{l}\text { Hatching } \\
\text { SVL }\end{array}$ & “" & 9 & - & 0.405 & 0.933 \\
\hline & & $\begin{array}{c}\text { Hatching } \\
\text { VTL }\end{array}$ & "“ & 9 & - & 1.422 & 0.175 \\
\hline & & Hatching TL & “ & 9 & - & 1.227 & 0.246 \\
\hline & & Hatching Wt & “" & 9 & - & 1.500 & 0.144 \\
\hline & & $\begin{array}{c}\text { Incubation } \\
\text { temperature } \\
\times \text { water } \\
\text { potential }\end{array}$ & “ & 18 & - & 1.394 & 0.127 \\
\hline \multirow{11}{*}{$\begin{array}{c}\text { Locomotor } \\
\text { Performance } \\
\text { (repeated } \\
\text { measures } \\
\text { GLM) }\end{array}$} & \multirow[t]{11}{*}{ Month } & $\begin{array}{l}\text { Incubation } \\
\text { temperature }\end{array}$ & All below & 2 & - & 2.407 & 0.097 \\
\hline & & $\begin{array}{c}\text { Water } \\
\text { potential }\end{array}$ & “" & 1 & - & 0.176 & 0.676 \\
\hline & & \multirow{9}{*}{$\begin{array}{c}\text { Incubation } \\
\text { regime }\end{array}$} & Sex & 1 & - & 0.065 & 0.799 \\
\hline & & & $\begin{array}{c}\text { Initial egg } \\
\text { mass }\end{array}$ & 1 & - & 0.001 & 0.978 \\
\hline & & & $\begin{array}{l}\text { Maternal } \\
\text { SVL }\end{array}$ & 1 & - & 0.230 & 0.633 \\
\hline & & & SVL & 1 & - & 0.376 & 0.542 \\
\hline & & & $\mathrm{TL}$ & 1 & - & 0.001 & 0.978 \\
\hline & & & $\mathrm{Wt}$ & 1 & - & 2.303 & 0.133 \\
\hline & & & $\mathrm{LL}$ & 1 & - & 0.348 & 0.557 \\
\hline & & & FL & 1 & - & 0.017 & 0.332 \\
\hline & & & Condition & 1 & - & 4.020 & 0.048 \\
\hline
\end{tabular}




\begin{tabular}{|c|c|c|c|c|c|c|c|}
\hline Test & $\begin{array}{c}\text { Within- } \\
\text { subject } \\
\text { Variables }\end{array}$ & $\begin{array}{c}\text { Between- } \\
\text { subject } \\
\text { Variable }\end{array}$ & Covariates & df & $\begin{array}{c}\text { Mean } \\
\text { Square }\end{array}$ & $\begin{array}{c}\text { F- } \\
\text { statistic }\end{array}$ & $\begin{array}{c}\mathbf{p -} \\
\text { value }\end{array}$ \\
\hline \multirow{24}{*}{$\begin{array}{c}\text { Locomotor } \\
\text { Performance } \\
\text { (repeated } \\
\text { measures } \\
\text { GLM) }\end{array}$} & Month & $\begin{array}{c}\text { Incubation } \\
\text { temperature } \\
\times \text { water } \\
\text { potential }\end{array}$ & All below & 2 & - & 0.037 & 0.903 \\
\hline & \multirow[t]{11}{*}{$\begin{array}{c}\text { Sprint } \\
\text { temperature }\end{array}$} & $\begin{array}{l}\text { Incubation } \\
\text { temperature }\end{array}$ & " & 4 & - & 2.482 & 0.046 \\
\hline & & $\begin{array}{c}\text { Water } \\
\text { potential }\end{array}$ & " & 2 & - & 0.454 & 0.637 \\
\hline & & \multirow{9}{*}{$\begin{array}{l}\text { Incubation } \\
\text { regime }\end{array}$} & Sex & 2 & - & 1.097 & 0.339 \\
\hline & & & $\begin{array}{c}\text { Initial egg } \\
\text { mass }\end{array}$ & 2 & - & 2.151 & 0.123 \\
\hline & & & $\begin{array}{c}\text { Maternal } \\
\text { SVL }\end{array}$ & 2 & - & 0.178 & 0.838 \\
\hline & & & SVL & 2 & - & 0.256 & 0.775 \\
\hline & & & TL & 2 & - & 0.073 & 0.930 \\
\hline & & & $\mathrm{Wt}$ & 2 & - & 0.776 & 0.464 \\
\hline & & & LL & 2 & - & 0.380 & 0.685 \\
\hline & & & FL & 2 & - & 0.279 & 0.757 \\
\hline & & & Condition & 2 & - & 5.114 & 0.008 \\
\hline & \multirow{12}{*}{$\begin{array}{c}\text { Month } \times \\
\text { sprint } \\
\text { temperature }\end{array}$} & $\begin{array}{l}\text { Incubation } \\
\text { temperature }\end{array}$ & All below & 4 & - & 2.149 & 0.077 \\
\hline & & $\begin{array}{c}\text { Water } \\
\text { potential }\end{array}$ & “" & 2 & - & 0.725 & 0.488 \\
\hline & & \multirow{9}{*}{$\begin{array}{l}\text { Incubation } \\
\text { regime }\end{array}$} & Sex & 2 & - & 0.416 & 0.661 \\
\hline & & & $\begin{array}{c}\text { Initial egg } \\
\text { mass }\end{array}$ & 2 & - & 6.968 & 0.002 \\
\hline & & & $\begin{array}{c}\text { Maternal } \\
\text { SVL }\end{array}$ & 2 & - & 0.074 & 0.929 \\
\hline & & & SVL & 2 & - & 1.161 & 0.319 \\
\hline & & & TL & 2 & - & 0.186 & 0.831 \\
\hline & & & $\mathrm{Wt}$ & 2 & - & 1.378 & 0.258 \\
\hline & & & LL & 2 & - & 0.866 & 0.425 \\
\hline & & & FL & 2 & - & 0.314 & 0.732 \\
\hline & & & Condition & 2 & - & 4.723 & 0.012 \\
\hline & & $\begin{array}{c}\text { Incubation } \\
\text { temperature } \\
\times \text { water } \\
\text { potential }\end{array}$ & All above & 4 & - & 1.164 & 0.329 \\
\hline
\end{tabular}


Table IIIe Results from statistical analysis of survival. A list is present below this table describing abbreviations used.

\begin{tabular}{|c|c|c|c|c|c|c|c|}
\hline Test & $\begin{array}{c}\text { Independent } \\
\text { Variable }\end{array}$ & $\begin{array}{c}\text { Dependent } \\
\text { Variable }\end{array}$ & Covariate & df & $\begin{array}{l}\text { Residual } \\
\text { Deviance }\end{array}$ & $\chi^{2}$ & $\begin{array}{c}\text { p- } \\
\text { value }\end{array}$ \\
\hline \multirow{7}{*}{$\begin{array}{l}\text { Survival to } \\
\text { Four } \\
\text { Months } \\
\text { (logistic } \\
\text { regression) }\end{array}$} & $\begin{array}{l}\text { Incubation } \\
\text { temperature }\end{array}$ & $\begin{array}{c}\text { Survive or } \\
\text { not }\end{array}$ & - & 120,2 & $\begin{array}{c}59.4 \\
\end{array}$ & 43.023 & $<0.001$ \\
\hline & $\begin{array}{c}\text { Water } \\
\text { potential }\end{array}$ & " & - & 121,1 & 102.4 & 0.001 & 0.970 \\
\hline & Sex & " & - & 121,1 & 101.9 & 0.475 & 0.491 \\
\hline & $\begin{array}{c}\text { Initial egg } \\
\text { mass }\end{array}$ & " & - & 121,1 & 101.8 & 0.622 & 0.431 \\
\hline & $\begin{array}{c}\text { Incubation } \\
\text { temperature } \times \\
\text { water } \\
\text { potential }\end{array}$ & “ & - & 119,3 & 59.3 & 0.010 & 0.748 \\
\hline & $\begin{array}{c}\text { Incubation } \\
\text { temperature } x \\
\text { sex }\end{array}$ & “ & - & 119,3 & 59.3 & 0.125 & 0.724 \\
\hline & $\begin{array}{c}\text { Incubation } \\
\text { temperature } \times \\
\text { initial egg } \\
\text { mass }\end{array}$ & “ & - & 119,3 & 56.7 & 2.666 & 0.103 \\
\hline
\end{tabular}

\section{Abbreviations used}

$\chi^{2}=$ chi square statistic.

df $=$ degrees of freedom.

$\mathrm{FL}=$ foot length.

GLM = general linear model .

LL = leg length.

SVL = snout-vent length.

$\mathrm{TL}=$ total length.

VTL = vent-tail length.

$\mathrm{Wt}=$ mass. 